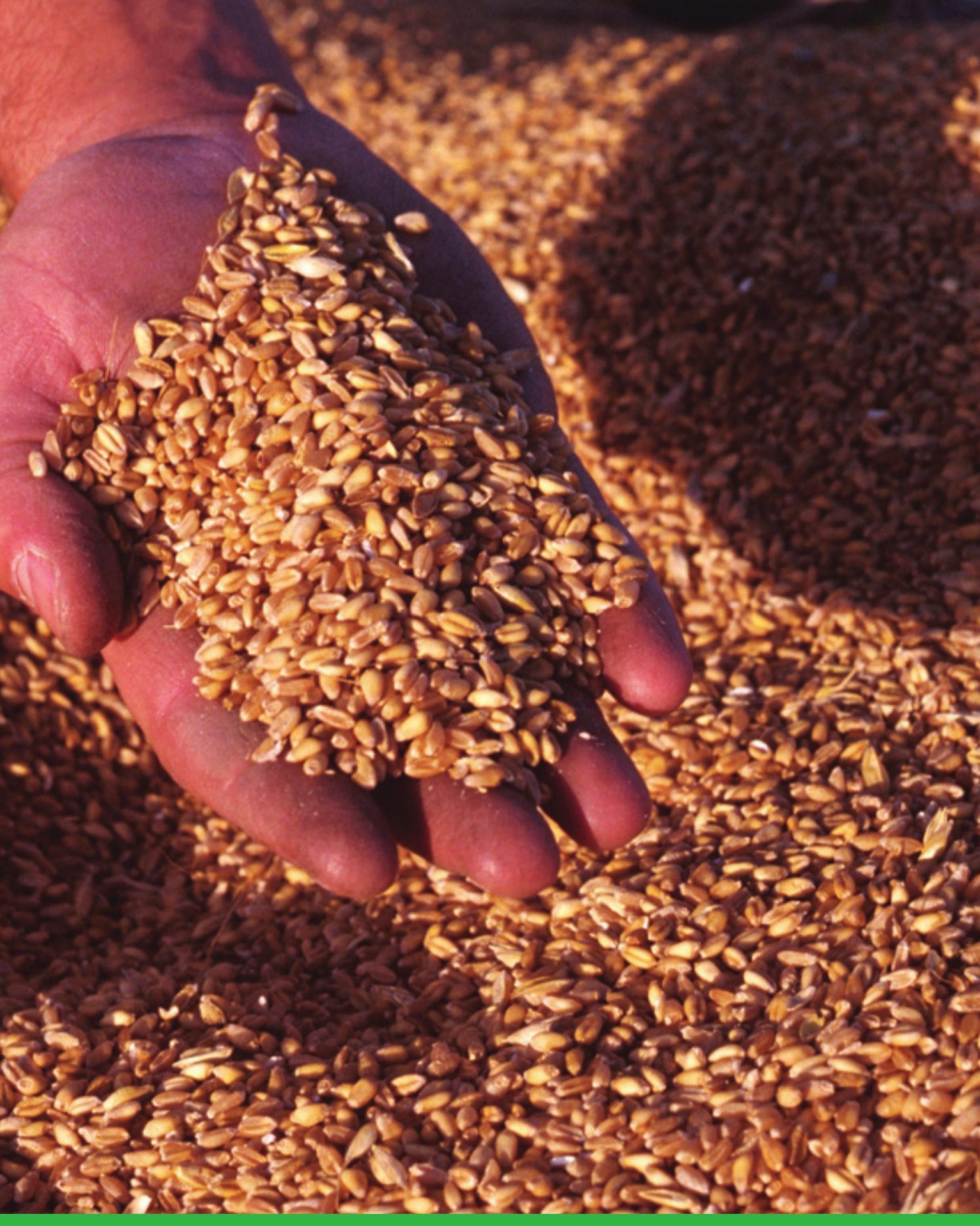

\title{
Chemische en fysische gevaren in de Nederlandse diervoederketen
}

H.J. van der Fels-Klerx, E.D. van Asselt, P. Adamse, M.N. Nijkamp, S.P.J. van Leeuwen, M. Pikkemaat, M. de Nijs,

H. Mol, L. van Raamsdonk, R. Hoogenboom, J. de Jong

WAGENINGEN

UNIVERSITY \& RESEARCH 



\section{Chemische en fysische gevaren in de Nederlandse diervoederketen}

H.J. van der Fels-Klerx, E.D. van Asselt, P. Adamse, M.N. Nijkamp, S.P.J. van Leeuwen, M. Pikkemaat, M. de Nijs, H. Mol, L. van Raamsdonk, R. Hoogenboom, J. de Jong 
Van der Fels-Klerx, H.J., Van Asselt, E.D., Adamse, P., Nijkamp, M.N., Van Leeuwen, S.P.J., Pikkemaat, M., De Nijs, M., Mol, H., Van Raamsdonk, L., Hoogenboom, R., De Jong, J., 2019. Chemische en Fysische gevaren in de Nederlandse diervoederketen. Wageningen, RIKILT Wageningen University \& Research, RIKILT-rapport 2019.002. 86 blz.; 6 fig.; 11 tab.; 205 ref.

Projectnummer: 1267344301

BAS-code: nvt

Projecttitel: Gevaarevaluatie Diervoederketen

Projectleider: H.J. van der Fels-Klerx

Dit rapport is gratis te downloaden op https://doi.org/10.18174/470704 of op www.wur.nl/rikilt (onder RIKILT publicaties).

(C) 2019 RIKILT Wageningen University \& Research, instituut binnen de rechtspersoon Stichting Wageningen Research. Hierna te noemen RIKILT.

Het is de opdrachtgever toegestaan dit rapport integraal openbaar te maken en ter inzage te geven aan derden. Zonder voorafgaande schriftelijke toestemming van het RIKILT is het niet toegestaan:

a. dit door RIKILT uitgebrachte rapport gedeeltelijk te publiceren of op andere wijze gedeeltelijk openbaar te maken;

b. dit door RIKILT uitgebrachte rapport, c.q. de naam van het rapport of RIKILT, geheel of gedeeltelijk te doen gebruiken ten behoeve van het instellen van claims, voor het voeren van gerechtelijke procedures, voor reclame of antireclame en ten behoeve van werving in meer algemene zin;

c. de naam van RIKILT te gebruiken in andere zin dan als auteur van dit rapport.

Postbus 230, 6700 AE Wageningen, T 03174802 56, E info.rikilt@wur.nl, www.wur.nl/rikilt. RIKILT is onderdeel van Wageningen University \& Research.

RIKILT aanvaardt geen aansprakelijkheid voor eventuele schade voortvloeiend uit het gebruik van de resultaten van dit onderzoek of de toepassing van de adviezen.

RIKILT-rapport 2019.002

Verzendlijst:

- Jacqueline Castenmiller

- Dick Sijms

- Jos Cornelese

- Koen Wienk

- Jan Schans 


\section{Inhoud}

Samenvatting $\quad \mathbf{5}$

$\begin{array}{ll}\text { Begrippenlijst en afkortingen } & 7\end{array}$

1

$\begin{array}{ll}\text { Introductie } & 11\end{array}$

2

Materiaal en Methode $\quad 12$

2.1 Gevarenanalyse $\quad 12$

2.2 Monitoring $\quad 12$

2.3 Toekomstige ontwikkelingen in de diervoedersector $\quad 12$

2.4 Selectie van gevaren $\quad 12$

$\begin{array}{ll}\text { Resultaten } & 14\end{array}$

$\begin{array}{lll}3.1 & \text { Diervoederketen } & 14\end{array}$

3.1.1 Primaire plantaardige productie (voeder)gewassen (geen of lichte $\begin{array}{ll}\text { bewerking, hoofd- en bijproducten) } & 15\end{array}$

3.1.2 Bijproducten en restproducten 16

$\begin{array}{lll}3.1 .3 & \text { Additieven } & 22\end{array}$

3.1.4 Productie van mengvoeder (incl. visvoer) 22

$\begin{array}{lll}3.1 .5 & \text { Samenstelling diervoeder } & 23\end{array}$

$\begin{array}{lll}3.2 & \text { Chemische gevaren } & 27\end{array}$

$\begin{array}{lll}3.2 .1 & \text { Dioxines en PCB's } & 27\end{array}$

3.2.2 Gebromeerde vlamvertragers 30

3.2.3 Perfluorverbindingen $\quad 32$

3.2.4 Zware metalen $\quad 34$

3.2.5 Mycotoxines $\quad 38$

3.2.6 Planttoxines $\quad 43$

3.2.7 Diergeneesmiddelen en coccidiostatica 46

$\begin{array}{lll}3.2 .8 & \text { Pesticiden } & 51\end{array}$

3.2.9 Minerale Oliën 56

3.2.10 Procescontaminanten $\quad 58$

$\begin{array}{lll}3.2 .11 & \text { Overige gevaren } & 60\end{array}$

$\begin{array}{lll}3.3 & \text { Dierlijke eiwitten } & 63\end{array}$

3.3.1 Bovine Spongiform Encephalopathy (BSE) 63

$\begin{array}{lll}3.3 .2 & \text { Regulering } & 63\end{array}$

3.3.3 Conclusie 64

3.4 Fysische gevaren $\quad 65$

3.4.1 Restanten van verpakkingsmateriaal 65

$\begin{array}{lll}3.4 .2 & \text { Conclusie } & 65\end{array}$

$\begin{array}{llr}4 & \text { Huidige monitoring } & 66\end{array}$

$\begin{array}{llr}5 & \text { Preventie en controle } & 69\end{array}$

$6 \quad$ Toekomstige ontwikkelingen in de diervoederketen $\quad 71$

$\begin{array}{lll}7 & \text { Conclusies en aanbevelingen } & 74\end{array}$

$8 \quad$ Dankwoord $\quad 76$

$\begin{array}{ll}\text { Literatuur } & \mathbf{7 7}\end{array}$ 



\section{Samenvatting}

De Nederlandse Voedsel- en Warenautoriteit (NVWA) bewaakt o.a. de veiligheid van voedsel en diervoeders, en handhaaft de levensmiddelen- en diervoederwetgeving. Als onderdeel hiervan controleert de NVWA onder andere diervoeder en levensmiddelen op de aanwezigheid van mogelijke gevaren voor mens en dier. Deze controle vindt steeds meer risico gebaseerd plaats, i.e. gericht op de gevaren die het grootste risico vormen voor de humane en dierlijke gezondheid.

Het belangrijkste doel van het huidige onderzoek was het in kaart brengen van de mogelijke chemische en fysische gevaren in de Nederlandse diervoederketen, als wel het identificeren van de belangrijkste gevaren gezien het potentiële risico voor de Nederlandse volksgezondheid. Daarnaast is gekeken naar maatregelen ter preventie en controle van de chemische en fysische gevaren, en zijn trends geïdentificeerd die mogelijk een effect kunnen hebben op de veiligheid van het diervoeder. Voor dit onderzoek is gebruik gemaakt van literatuuronderzoek, RASFF meldingen en van monitoringsgegevens als wel van de kennis van experts.

De diervoederketen is door de NVWA opgedeeld in 11 subketens en voor elk van deze subketens is het (mogelijke) optreden van de volgende chemische gevaren beschreven: dioxines en PCB's, gebromeerde vlamvertragers, zware metalen, mycotoxines, planttoxines, diergeneesmiddelen, pesticiden, minerale oliën, procescontaminanten, perfluorverbindingen, hormonen, en GGO. Tevens is het mogelijke voorkomen beschreven van dierlijke eiwitten en fysische gevaren in de diervoederketen. Voor elk van de chemische en fysische gevaren is ook de overdracht naar dierlijke producten aangegeven.

Op basis van de bevindingen met betrekking tot de aanwezigheid in diervoeder, de overdracht naar dierlijke producten én de toxiciteit is een prioritering van de gevaren aangegeven met het oog op het mogelijke risico voor de Nederlandse volksgezondheid. Stoffen met een hoge prioriteit zijn dioxines, aflatoxines en pyrrolizidine-alkaloïden (PA's), en stoffen met een medium prioriteit zijn zware metalen en dierlijke eiwitten. Verontreiniging van diervoeder met diermeel wordt weinig gevonden maar kan hoge impact hebben en dient om die reden opgenomen te worden in het monitoringsprogramma. Voor een aantal stoffen bleek er te weinig informatie te zijn over het voorkomen in diervoeder en/of mogelijke overdracht naar voedselproducten van dierlijke oorsprong en dus konden voor deze stoffen geen conclusies getrokken worden. Dit betrof de planttoxines (behalve PA's), minerale oliën, procescontaminanten, perfluorverbindingen en nanodeeltjes. Ook andere kennisleemtes zijn geïdentificeerd, zoals over het natuurlijk voorkomen van chlooramfenicol in gras.

De huidige monitoring door de NVWA is vastgelegd in het Nationaal Plan (NP) Diervoeders dat jaarlijks wordt bijgesteld. Hierin wordt het aantal monsters vastgelegd evenals de aard en frequentie van de controles. De uitkomsten van onderhavige onderzoek kunnen gebruikt worden om dit NP Diervoeders bij te stellen. Maar ook andere overwegingen dan volksgezondheidsrisico spelen mee in opnemen van gevaren in het NP diervoeders, zoals schadelijkheid van de stoffen voor milieu, diergezondheid en welzijn, als wel antibioticum resistentie.

Diervoederbedrijven borgen de voedselveiligheid via kwaliteitssystemen als GMP+ en/of door deelname aan Securefeed. Securefeed voert een risico gebaseerde monitoring uit waarbij stoffen in een risicoklasse geplaatst worden op basis van ernst en voorkomen van de stoffen.

De diervoedersector is continu in ontwikkeling en er is een aantal trends gesignaleerd met mogelijke gevolgen voor de veiligheid van diervoeder: alternatieve (nieuwe) ingrediënten voor diervoeder (zoals insecten en algen), verandering in voersamenstelling (zoals meer plantaardige ingrediënten in visvoer), hergebruiken van grondstoffen (met mogelijke toename in gebruik van voormalige levensmiddelen), klimaatverandering (effect op mycotoxines en planttoxines), toenemende vraag naar dierlijke productie, toename in aantal zelfmengers en toename in technologische ontwikkelingen (bijvoorbeeld hydrolyse van eiwitten). Het wordt daarom aanbevolen deze trends nauwlettend in de gaten te houden. 


\section{Begrippenlijst en afkortingen}

\begin{tabular}{|c|c|c|}
\hline Begrip & Definitie & Bron \\
\hline $\begin{array}{l}\text { Aanvullende } \\
\text { diervoeders }\end{array}$ & $\begin{array}{l}\text { Mengsels van diervoeders die een hoog } \\
\text { gehalte aan bepaalde stoffen bevatten en } \\
\text { door hun samenstelling slechts samen met } \\
\text { andere diervoeders een totaal dagrantsoen } \\
\text { vormen }\end{array}$ & Richtlijn 2002/32/EG \\
\hline$A D$ & $\begin{array}{l}\text { Actiedrempel voor het verrichten van } \\
\text { onderzoek door de lidstaten }\end{array}$ & Richtlijn 2002/32/EG \\
\hline $\begin{array}{l}\text { Additieven of } \\
\text { toevoegingsmiddelen }\end{array}$ & $\begin{array}{l}\text { Stoffen, micro-organismen of preparaten die } \\
\text { geen voedermiddelen noch voormengsels } \\
\text { zijn en die opzettelijk aan diervoeder of } \\
\text { water worden toegevoegd }\end{array}$ & Verordening (EG) 1831/2003 \\
\hline ANF & Anti-Nutritionele Factoren & \\
\hline BFR & $\begin{array}{l}\text { Broomhoudende vlamvertragers } \\
\text { (brominated flame retardants) }\end{array}$ & \\
\hline $\begin{array}{l}\text { Botanische } \\
\text { verontreiniging }\end{array}$ & $\begin{array}{l}\text { Natuurlijke vreemde bestanddelen die } \\
\text { onschadelijk zijn voor de gezondheid van } \\
\text { mens of dier of voor het milieu, waaronder } \\
\text { stro- en kafdeeltjes, zaden van andere } \\
\text { geteelde soorten, onkruidzaden }\end{array}$ & (NVWA) \\
\hline BSE & $\begin{array}{l}\text { Boviene Spongiforme Encefalopathie } \\
\text { (gekkekoeienziekte) }\end{array}$ & \\
\hline Circulaire economie & $\begin{array}{l}\text { Maximaal hergebruiken eindige } \\
\text { grondstoffen, minimaliseren afhankelijkheid } \\
\text { van niet hernieuwbare grond- en hulpstoffen } \\
\text { en een bodem in balans die tot in lengte van } \\
\text { jaren in staat is de wereld te voeden }\end{array}$ & (NEVEDI, 2016a) \\
\hline CWD & Chronic Wasting Disease & \\
\hline DDGS & Dried distiller grains with solubles & \\
\hline DDT & Dichlorodifenyltrichloroethaan & \\
\hline Diervoeders & $\begin{array}{l}\text { Producten van plantaardige of dierlijke } \\
\text { oorsprong in natuurlijke staat, vers, of } \\
\text { verduurzaamd, en de afgeleide producten } \\
\text { van de industriële verwerking ervan, } \\
\text { alsmede organische of anorganische stoffen, } \\
\text { al dan niet gemend, met of zonder } \\
\text { toevoegingsmiddelen, en bestemd voor } \\
\text { vervoedering }\end{array}$ & Richtlijn 2002/32/EG \\
\hline DON & Deoxynivalenol & \\
\hline EFSA & European Food Safety Authority & \\
\hline FEEDAP & $\begin{array}{l}\text { EFSA Panel on Additives and Products or } \\
\text { Substances used in Animal Feed }\end{array}$ & \\
\hline GAP & $\begin{array}{l}\text { Goede Agrarische Praktijken (Good } \\
\text { Agricultural Practice) }\end{array}$ & \\
\hline GC & GasChromatografie & \\
\hline GE & Glycidolesters & \\
\hline GGO & Genetisch Gemodificeerde Organismen & \\
\hline HBGV & Health Based Guidance Values & \\
\hline HACCP & Hazard Analysis Critical Control Point & \\
\hline HBCDD & Hexabromocyclodododecaan & \\
\hline
\end{tabular}




\begin{tabular}{|c|c|c|}
\hline Begrip & Definitie & Bron \\
\hline HIPC & Hittegeïnduceerde procescontaminanten & \\
\hline HMF & Hydroxymethylfurfural & \\
\hline Import & $\begin{array}{l}\text { Grondstoffen die van buiten de EU naar } \\
\text { Nederland worden getransporteerd }\end{array}$ & $\begin{array}{l}\text { NVWA, persoonlijke } \\
\text { communicatie }\end{array}$ \\
\hline Invoer & $\begin{array}{l}\text { Grondstoffen die van binnen de EU naar } \\
\text { Nederland worden getransporteerd }\end{array}$ & $\begin{array}{l}\text { NVWA, persoonlijke } \\
\text { communicatie }\end{array}$ \\
\hline JEFCA & $\begin{array}{l}\text { Joint FAO/WHO Expert Committee on Food } \\
\text { Additives }\end{array}$ & \\
\hline KAP & Kwaliteitsprogramma Agrarische Producten & https://chemkap.rivm.nl/ \\
\hline Krachtvoer & $\begin{array}{l}\text { Diervoeder met een hoge energiewaarde. } \\
\text { Kan vetten bevatten, granen en hun } \\
\text { bijproducten, eiwitrijke oliezaden of cakes en } \\
\text { (dierlijke) bijproducten }\end{array}$ & www.britannica.com \\
\hline LAP & $\begin{array}{l}\text { Landelijk AfvalbeheerPlan van } \\
\text { Rijkswaterstaat }\end{array}$ & http://lap3.nl/ \\
\hline MCPD & Monochloorpropaandiol & \\
\hline Mengvoeder & $\begin{array}{l}\text { Mengsels van voedermiddelen, al dan niet } \\
\text { met toevoegingsmiddelen en bestemd voor } \\
\text { vervoedering in de vorm van volledig } \\
\text { diervoeders of aanvullende diervoeders }\end{array}$ & Richtlijn 2002/32/EG \\
\hline ML & Maximumgehalte (EN: maximum level) & Richtlijn 2002/32/EG \\
\hline MPA & Medroxy progesteron acetaat & \\
\hline $\begin{array}{l}\text { MRL } \\
\text { (diergeneesmiddelen) }\end{array}$ & $\begin{array}{l}\text { Maximum Residue Limit: het } \\
\text { maximumgehalte aan residuen van een } \\
\text { farmacologisch werkzame stof dat } \\
\text { toelaatbaar is in levensmiddelen van } \\
\text { dierlijke oorsprong (maximumwaarde voor } \\
\text { residuen) }\end{array}$ & $\begin{array}{l}\text { Verordening (EG) 470/2009 } \\
\text { (art 1.1a) }\end{array}$ \\
\hline $\begin{array}{l}\text { MRL } \\
\text { (gewasbeschermings- } \\
\text { middelen) }\end{array}$ & $\begin{array}{l}\text { Maximum Residue Level: het hoogste } \\
\text { wettelijk toegestane concentratieniveau van } \\
\text { een bestrijdingsmiddelenresidu in of op een } \\
\text { levensmiddel of diervoeder, overeenkomstig } \\
\text { onderhavige verordening vastgesteld op } \\
\text { basis van goede landbouwpraktijken en de } \\
\text { laagste blootstelling van consumenten die } \\
\text { noodzakelijk is met het oog op de } \\
\text { bescherming van kwetsbare consumenten }\end{array}$ & $\begin{array}{l}\text { Verordening (EG) 396/2005 } \\
\text { (art 3.2d) }\end{array}$ \\
\hline Pesticiden & $\begin{array}{l}\text { Stoffen die schadelijke organismen of } \\
\text { ziektes voorkomen, vernietigen of beheersen } \\
\text { of plant(product)en tijdens productie, opslag } \\
\text { en transport beschermen. Pesticiden } \\
\text { omvatten gewasbeschermingsmiddelen en } \\
\text { biociden }\end{array}$ & $\begin{array}{l}\text { http://ec.europa.eu/food/plan } \\
\text { t/pesticides_en }\end{array}$ \\
\hline PA's & Pyrrolizidine-alkaloïden & \\
\hline PBDE & Polybroom difenylethers & \\
\hline PCB & Polychloorbifenyl & \\
\hline PCDD & Gechloreerde dibenzo-p-dioxines & \\
\hline PCDF & Gechloreerde dibenzofuranen & \\
\hline PFOA & Perfluoroktaanzuur & \\
\hline PFOS & Perfluoroktaansulfonzuur & \\
\hline PAK's & Polycyclische Aromatische Koolwaterstoffen & \\
\hline POP & Persistent Organic Pollutant & \\
\hline Procescontaminanten & $\begin{array}{l}\text { Contaminanten die tijdens het } \\
\text { productieproces ontstaan en in de keten } \\
\text { terechtkomen }\end{array}$ & \\
\hline
\end{tabular}




\begin{tabular}{|c|c|c|}
\hline Begrip & Definitie & Bron \\
\hline RASFF & Rapid Alert System for Food and Feed & $\begin{array}{l}\text { https://ec.europa.eu/food/saf } \\
\text { ety/rasff_en }\end{array}$ \\
\hline Ruwvoer & $\begin{array}{l}\text { Diervoeder met meer dan } 18 \% \text { ruwe vezels } \\
\text { en minder dan } 20 \% \text { ruw eiwit in het droge- } \\
\text { stofgehalte }\end{array}$ & FAO, 2000 \\
\hline TCDD & 2,3,7,8-tetrachloordibenzo-p-dioxine & \\
\hline TEF & $\begin{array}{l}\text { Toxic Equivalency Factor (Toxische } \\
\text { equivalentiefactor) }\end{array}$ & \\
\hline TEQ & Toxic Equivalent (Toxische equivalent) & \\
\hline TSE & Transmissible Spongiform Encephalopathies & \\
\hline Veekoek & $\begin{array}{l}\text { de reststromen (schilfers en schroot) van de } \\
\text { olieproductie uit bonen, pitten en zaden van } \\
\text { raapzaad, kokos, palmpitten, sojabonen en } \\
\text { zonnebloemzaad }\end{array}$ & Gosselink en Smelt, 2006 \\
\hline Voedermiddel & $\begin{array}{l}\text { De verschillende producten van plantaardige } \\
\text { of dierlijke oorsprong in natuurlijke staat, } \\
\text { vers of verduurzaamd, en de afgeleide } \\
\text { producten van de industriële verwerking } \\
\text { ervan, alsmede organische of anorganische } \\
\text { stoffen, met of zonder toevoegingsmiddelen, } \\
\text { en bestemd voor vervoedering, hetzij als } \\
\text { zodanig, hetzij na verwerking, voor de } \\
\text { bereiding van mengvoeders of als drager bij } \\
\text { voormengsels }\end{array}$ & Richtlijn 2002/32/EG \\
\hline Volledig diervoeder & $\begin{array}{l}\text { Mengsel van diervoeders die door hun } \\
\text { samenstelling op zichzelf een totaal } \\
\text { dagrantsoen vormen }\end{array}$ & Richtlijn 2002/32/EG \\
\hline Voormengsels & $\begin{array}{l}\text { Mengsels van toevoegingsmiddelen of } \\
\text { mengsels van een of meer } \\
\text { toevoegingsmiddelen met stoffen die } \\
\text { dragers vormen, die bestemd zijn voor de } \\
\text { bereiding van diervoeders }\end{array}$ & Richtlijn 2002/32/EG \\
\hline ZEA & Zearalenon & \\
\hline
\end{tabular}




\section{$1 \quad$ Introductie}

De Nederlandse Voedsel- en Warenautoriteit (NVWA) bewaakt o.a. de veiligheid van voedsel en diervoeders, en handhaaft de levensmiddelen- en diervoederwetgeving. De drie kerntaken van de NVWA zijn handhaving (zowel toezicht als opsporing), risicobeoordeling en risicocommunicatie. De taak van toezicht op de naleving van wet- en regelgeving omvat de hele keten, van boer tot supermarkt. De NVWA werkt aan de structurele verbetering van toezicht. Begin 2014 heeft de Tweede Kamer ingestemd met het verbeterplan van de NVWA waarin de contouren zijn beschreven om het toezicht te verbeteren. Wetenschappelijke risicoanalyse en prioritering vormt de basis voor het toezicht van de NVWA. Om uitvoering te geven aan het verbeterplan worden door het Bureau Risicobeoordeling \& Onderzoeksprogrammering (BURO) van de NVWA de risico's in de verschillende ketens, waaronder de diervoederketen, in kaart gebracht en geprioriteerd.

Om tot die prioritering te komen is het nodig de chemische en fysische gevaren die zich in de (gehele) diervoederketen kunnen voordoen, en mogelijk een risico voor de mens kunnen vormen, in beeld te brengen. Voor dit beeld zijn o.a. gegevens nodig over het optreden van de gevaren in de diervoederketen en over de overdracht van de gevaren naar dierlijke producten (die door de mens worden geconsumeerd).

Het doel van onderhavige studie is een wetenschappelijke inventarisatie - middels een deskstudie, analyse van monitoringsgegevens en consultatie van experts - van de chemische en fysische gevaren die zich in de verschillende schakels van de diervoederketen kunnen voordoen c.q. kunnen worden geïntroduceerd, en overgedragen worden naar dierlijke producten, waar ze (vanwege toxiciteit) een mogelijk risico voor de gezondheid van de consument kunnen vormen via consumptie. De keteninformatie (indeling van de diervoederketen in 11 subketens en beschrijving van elk van de subketens) die door de NVWA is aangeleverd, is hierbij als startpunt gebruikt. Petfood is in dit onderzoek niet meegenomen, omdat chemische en fysische gevaren die mogelijk in dit type diervoeder kunnen voorkomen geen gevolgen hebben voor de gezondheid van de consument van dierlijke producten. Daarnaast vallen gevaren in de diervoederketen die een risico kunnen vormen voor milieu, diergezondheid en/of dierenwelzijn, als wel antibioticumresistentie en fraudelente zaken buiten deze studie.

Ten behoeve van de inventarisatie zijn de volgende vragen aan de orde gekomen:

1. Wat zijn de chemische en fysische gevaren die zich in de keten kunnen voordoen; Wat is het optreden (prevalentie en concentratie) van de chemische gevaren en de incidentie van de fysische gevaren in de keten; Wat is bekend over de overdracht van die stoffen naar voedselproducten (bedoeld voor humane consumptie) van dierlijke oorsprong?

2. In welke schakels van de keten doen de gevaren zich voor c.q. worden ze geïntroduceerd?

3. Welke mogelijkheden voor interventie zijn in de keten aanwezig om de aanwezigheid van de gevaren in diervoeder te minimaliseren?

4. Welke ontwikkelingen in de keten die de diervoederveiligheid vergroten of verkleinen zijn er tot 2025 te verwachten?

5. Hoe zien lopende monitoringsprogramma's eruit voor contaminanten in diervoeder, zowel privaat als publiek (NVWA)? 


\section{Materiaal en Methode}

\section{$2.1 \quad$ Gevarenanalyse}

Experts van RIKILT zijn gevraagd de verschillende chemische en fysische gevaren die kunnen voorkomen in diervoeder te beschrijven. Hen is gevraagd met name aandacht te besteden aan die gevaren die via overdracht naar dierlijke producten een gevaar zouden kunnen vormen voor de consument en de schakels in de keten aan te geven, waarin deze gevaren worden geïntroduceerd. De experts die aan dit onderzoek hebben bijgedragen staan in de auteurslijst van dit rapport. De experts hebben vanuit hun expertise referenties aangedragen en een beschrijving gegeven van de verschillende gevaren zoals aangegeven in 3.2. Aanvullend zijn EFSA-rapportages over de diverse chemische en fysische gevaren doorgenomen, waarmee de gevaarbeschrijvingen zijn aangevuld. Extra informatie is verkregen door middel van literatuuronderzoek in wetenschappelijke artikelen, waarbij specifiek gezocht is op de gevaren aangedragen door de experts.

\section{$2.2 \quad$ Monitoring}

Gegevens over het optreden (prevalentie en concentratie) van chemische gevaren in diervoeders zijn verkregen uit rapportages over trendanalyses; deze trendanalyses zijn gebaseerd op gegevens uit de KAP-databank. Het betrof trendanalyses zoals beschreven in de volgende rapporten (Adamse et al., 2007; Adamse et al., 2009a; Adamse et al., 2014; Adamse et al., 2011; Adamse et al., 2009b; Schoss et al., 2012). Gegevens over het optreden van zware metalen en dioxines zijn gebaseerd op recente artikelen van Adamse et al. (2017; 2015). Voor de jaren 2005 t/m 2015 zijn tevens alle meldingen met betrekking tot chemische en fysische gevaren in diervoeder uit de RASFF-databank geanalyseerd.

Informatie over de huidige monitoring door de overheid/NVWA is verkregen vanuit het Nationaal Plan Diervoeder (2011-2016). De huidige monitoring door de diervoederindustrie is beschreven op basis van een rapport van de Jong et al. (2016).

De inventarisatie van preventie- en controlemaatregelen is gebaseerd op rapporten van SecureFeed (2016a; 2016b) en de Jong et al. (2016), aangevuld met informatie over GMP+ (GMP+International, 2016).

\subsection{Toekomstige ontwikkelingen in de diervoedersector}

Trends in de diervoedersector zijn in kaart gebracht door RIKILT experts en SecureFeed te vragen naar ontwikkelingen in de diervoedersector. Genoemde trends zijn vervolgens onderzocht door gerichte literatuurstudie uit te voeren om meer informatie en inzicht te krijgen in de genoemde ontwikkelingen. Er is gezocht naar literatuur over alternatieve eiwitbronnen, circulaire economie en de vervanging van marine ingrediënten door plantaardige ingrediënten. Daarnaast zijn de jaarverslagen en websites van de diervoederindustrie geraadpleegd, zoals Nutreco, ABZ Diervoeding en NEVEDI.

\subsection{Selectie van gevaren}

Uitgangspunt voor deze studie zijn groepen van mogelijke chemische en fysische gevaren ("Iong list") die zich kunnen voordoen in diervoeder dat in Nederland wordt geproduceerd en/of op de markt wordt gebracht. Binnen elke groep, is op basis van optreden van het gevaar, een focus gelegd op die 
gevaren die voor Nederland relevant zijn ("intermediate list") d.w.z. optreden in diervoeder dat in Nederland wordt geproduceerd en/of in Nederland op de markt wordt gebracht. Dit zijn de stoffen die tijdens de publieke en private monitoring (Nationaal Plan diervoeders, SecureFeed, en/of RASFF) wel eens zijn aangetroffen in diervoeder. Deze stoffen zijn beschreven in hoofdstuk 3 ("Aanwezigheid in sub-ketens"). Vervolgens is op basis van bevindingen m.b.t. de mogelijke overdracht naar dierlijke producten, toxiciteit en een inschatting van de consumptie van deze producten door de Nederlandse consument, een selectie gemaakt van de belangrijkste gevaren ("short list"). De short list is verder ingedeeld naar stoffen met medium en hoge prioriteit voor monitoring. Toxische stoffen die én regelmatig gevonden worden in diervoeder én overgedragen worden naar producten die (regelmatig) geconsumeerd worden, hebben een hoge prioriteit voor de monitoring. Als aan één van deze voorwaarden niet is voldaan zijn de stoffen van short list ingedeeld in medium prioriteit voor monitoring. Alle overige stoffen hebben lage prioriteit voor de monitoring. 


\section{Resultaten}

\subsection{Diervoederketen}

De diervoederketen omvat de productie, handel en het op de markt brengen van voedermiddelen, voormengsels, toevoegingsmiddelen, mengvoeder en alle andere producten die bedoeld zijn om te worden gebruikt of gebruikt worden voor het voederen van dieren. De diervoederketen is een complex netwerk, waarbij verschillende soorten actoren betrokken zijn, waaronder gewasproducenten, handelaars, producenten van tussen producten (verwerkers) en van eindproducten (Fink-Gremmels 2012). De keten start met de teelt en/of import van primaire (akkerbouw-)producten, de aankoop en import van bijproducten en additieven en loopt via de verwerkers naar de laatste schakel; de boerderij waarop dieren worden gehouden en gevoederd. Figuur 1 geeft een schematisch overzicht van de diervoederketen. Hierbij is de keten door de NVWA onderverdeeld in de volgende 11 sub-ketens:

1. Primaire plantaardige productie van (voeder)gewassen (geen of lichte bewerking, hoofd- en bijproducten)

2. Handel en verwerking van plantaardige producten, eerste fase

3. Handel en verwerking van plantaardige producten, tweede fase

4. Verwerking van voormalige levensmiddelen (plantaardig)

5. Verwerking van dierlijke producten, eerste fase

6. Verwerking van dierlijke producten, tweede fase

7. Verwerking van voormalige levensmiddelen (dierlijke retourstromen)

8. Verwerking (verwaarding) van overige bijproducten tot voedermiddelen

9. Chemische productie van additieven

10. Productie van mengvoer

11. Productie van petfood 


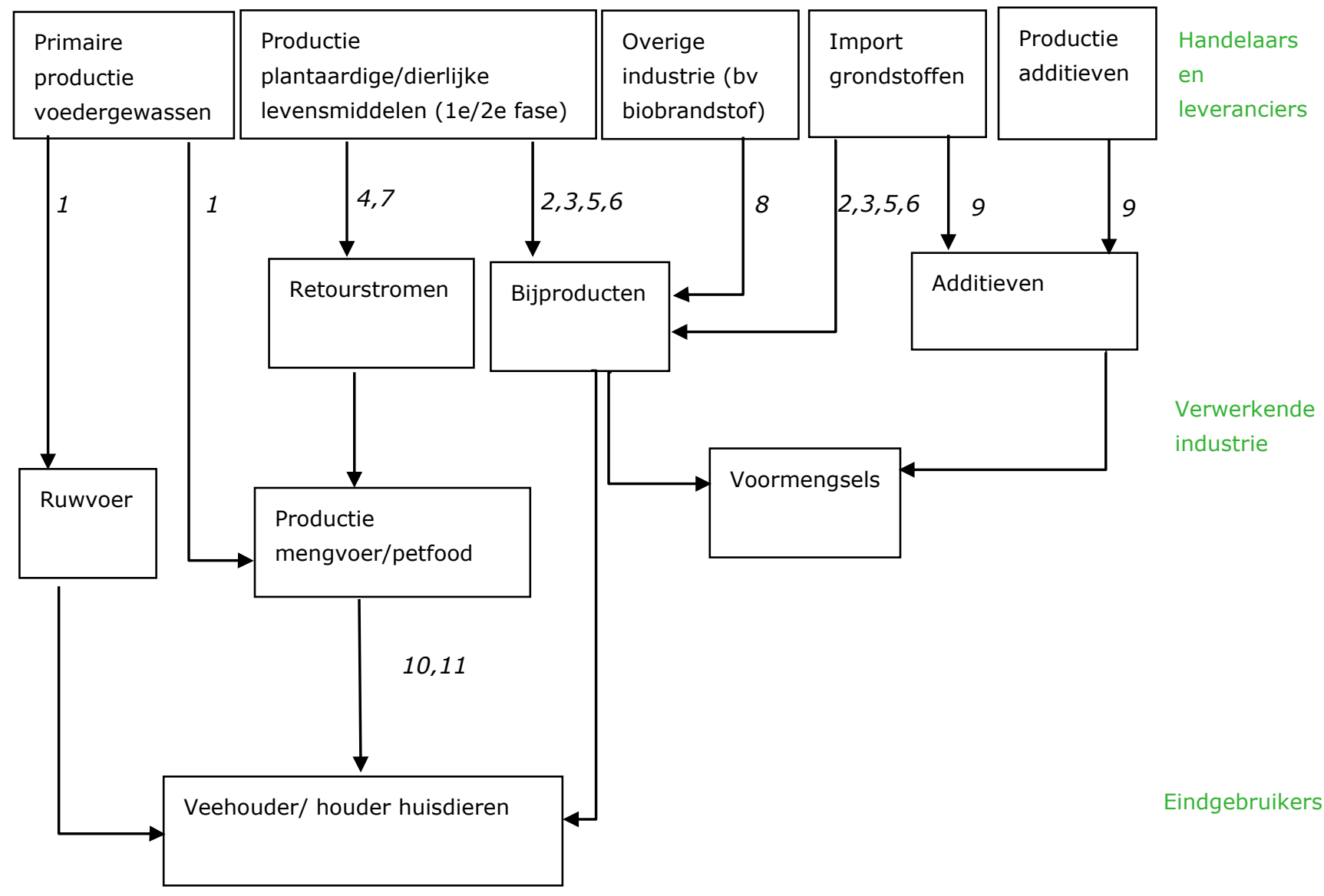

Figuur 1 Schematische en vereenvoudigde weergave van de diervoederketen. De nummers geven de verschillende sub-ketens (sectie 3.1) weer.

Petfood wordt in dit onderzoek niet meegenomen, omdat chemische en fysische gevaren die in dit type diervoeder kunnen voorkomen geen gevolgen hebben voor de gezondheid van de Nederlandse consument van dierlijke producten. De overige sub-ketens worden in de volgende alinea's kort besproken.

\subsubsection{Primaire plantaardige productie (voeder)gewassen (geen of lichte bewerking, hoofd- en bijproducten)}

De sub-keten omvat de veredeling, teelt en handel van uitgangsmateriaal voor voedergewassen, de teelt van eindproducten van voedergewassen, de bewaring en bewerking van eindproducten tot diervoeder, transport en voedering. De bewerkingen betreffen uitsluitend lichte bewerkingen zoals drogen van hooi en verhakselen en inkuilen van snijmaïs. Het gaat hierbij hoofdzakelijk om plantaardige voedermiddelen - zowel hoofd- als bijproducten - die geen of een lichte bewerking hebben ondergaan, en die bestemd zijn voor vervoedering door de veehouder of voor verdere verwerking in de diervoederindustrie (met name voor de productie van mengvoeders). De producenten van deze plantaardige voedermiddelen in zijn (inter)nationale veehouders, akkerbouwers en tuinbouwers. In Nederland gaat het in 2015 om onderstaande arealen per product (Figuur 2) (www.statline.cbs.nl).

Gewassen waarvan het hoofdproduct bestemd is voor andere doelen dan diervoeder zijn geen onderdeel van deze keten. Voorbeelden zijn de teelt van aardappel, koolzaad en maïs en tarwe voor humane consumptie en zetmeelproductie. Het gebruik van licht bewerkte of onbewerkte bijproducten van deze teelten voor diervoeder, zoals het stro van graangewassen en erwten, wordt beschouwd in de sub-keten 'Verwerking van plantaardige producten, eerste fase'. 


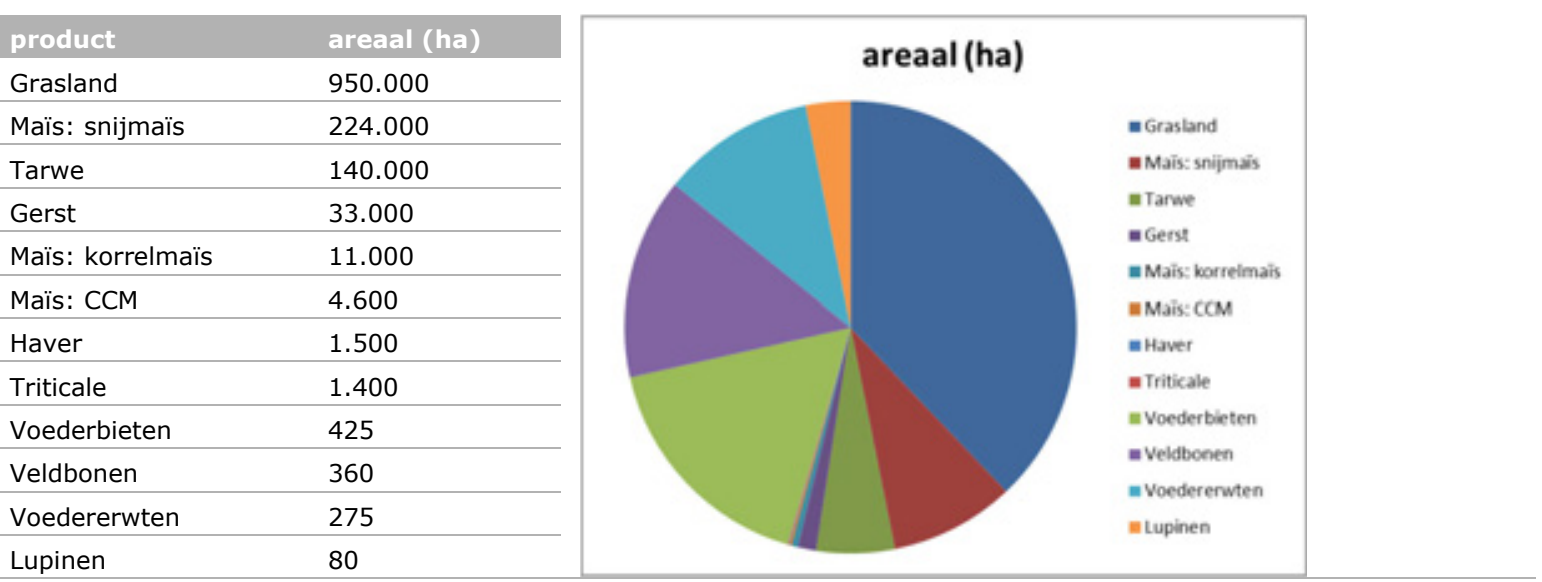

Figuur 2 Productiearealen plantaardige voedermiddelen in Nederland in 2015 (www.statline.cbs.nI).

Ruwvoeders zoals gras en snijmaïs worden vaak door veehouders zelf geteeld voor vervoedering op het eigen bedrijf, veelal worden deze voeders gevoerd aan melkkoeien en jongvee op melkveebedrijven. Deze producten worden onbewerkt of na eenvoudige bewerking (malen, drogen), eventueel na korte of langere tijd van opslag (inkuilen van gras, in balen persen), als diervoeder gebruikt. Er is weinig zicht en controle op deze productie.

Andere plantaardige voedermiddelen, zoals granen (tarwe, gerst, haver, triticale, korrelmaïs), bieten en aardappelen, worden met name door akkerbouwers geteeld. Slechts een klein deel van de totale beschikbare hoeveelheid granen voor diervoeder wordt in Nederland geteeld. Dit betreft overwegend tarwe (voertarwe), triticale en haver. Het grootste deel wordt ingevoerd, met name uit Frankrijk, Duitsland en het Verenigd Koninkrijk. In paragraaf 3.1.5 staan de importgegevens van granen naar Nederland uitgewerkt.

Gebruikers van plantaardige voedermiddelen uit de primaire productie zijn veehouders en de mengvoederindustrie. Producten zoals snijmaïs, gras, corn cob mix (ccm), diverse strosoorten en voederbieten zijn direct voor veehouders bestemd. Producten zoals granen zijn in hoofdzaak voor de mengvoederindustrie bestemd (van der Roest J., 2004).

\subsubsection{Bijproducten en restproducten}

Mengvoeders bevatten vrijwel altijd ook reststromen van de voedselproductie. Reststromen kunnen ontstaan bij allerlei verschillende bedrijfstypen met een grote diversiteit in productieprocessen en producten, variërend van producten die ontstaan bij de eerste verwerking van agrarische producten in de agro-industrie tot producten die ontstaan bij de verdere ver- en bewerking in de levensmiddelen-, chemische of farmaceutische industrie. Een bijproduct is een stof/voorwerp dat het resultaat is van een productieproces dat niet in de eerste instantie bedoeld was voor de productie van die stof of voorwerp en geen afvalstof is volgens de voorwaarden genoemd in Richtlijn 2008/98/EG. Deze (organische) reststromen ontstaan als bijproduct uit organische grondstoffen of halffabricaten, en kunnen in bepaalde mate worden verwerkt tot hoogwaardige producten (voor humane consumptie) of worden toegepast in diervoeder en non-food producten.

Voorbeelden van restromen die worden gebruikt in mengvoeders zijn: olieproductie (schillen, schroten), meel en zetmeel (kaf, zemelen, gries), bier (bierbostel), bakkerijproducten (deeg, overdatum producten), reststromen die dierlijke bijproducten bevatten of daar geheel uit bestaan (slachtbijproducten, voedselproducten die ten dele bestaan uit dierlijke producten), en een aantal kleinere stromen.

Voor de productie van diervoeders geldt in principe de Wet Dieren, waarin opgenomen de bepalingen van de Kaderwet Diervoeders (geldend tot 2013). Uitgangspunt voor de Nederlandse situatie is de Europese wetgeving, die volledig wordt gevolgd en geïmplementeerd. Op Europees niveau worden productie en gebruik van diervoeders geregeld in Verordening (EC) 178/2002 (de algemene levensmiddelen verordening). Artikel 3 lid 4 geeft als definitie van diervoeder: "alle stoffen en producten, inclusief additieven, verwerkt, gedeeltelijk verwerkt of onverwerkt, die bestemd zijn om te worden gebruikt voor orale vervoedering aan dieren". Verdere bepalingen staan in Verordening (EC) 
767/2009. In Appendix III van deze verordening staat een lijst van materialen die verboden zijn als diervoeder(-ingrediënt). Dit betreft o.a. mest, bouw- en stadsafval, glas, huishoudelijk afval, behandelde zaden, huiden (leer) en hout, verpakkingsmateriaal. Voor bijproducten die geschikt zijn voor, en ook als zodanig gebruikt worden als ingrediënten in diervoeders, is de Catalogus Diervoederingrediënten van de EC beschikbaar (Verordening EC/68/2013). Deze regelt niet de toestemming, maar regelt dat een erkend ingrediënt met een eenduidige definitie en etikettering op de markt wordt gebracht. In deze catalogus staan ruim 600 verschillende typen "feed materials".

Bijproducten kunnen onderverdeeld worden in plantaardige reststromen (vanuit onder andere de graan- en aardappelverwerkende- en suikerindustrie), dierlijke reststromen (vanuit de zuivelindustrie, en vlees-, vis- en ei-verwerkende industrie), gemengde reststromen, die zowel plantaardige als dierlijke componenten bevatten, en overige stromen vanuit onder andere de chemische en farmaceutische industrie. Een aantal bedrijven heeft zich daarin gespecialiseerd en houdt zich bezig met de verwerking van deze producten. De drie grootste bedrijven in Nederland zijn ForFarmers, Bonda en Duynie. Forfarmers en Bonda verwerken zowel plantaardige als dierlijke componenten. In de (levensmiddelen)industrie in andere EU-lidstaten of in derde landen komen ook bijproducten vrij die opgenomen kunnen worden in de Nederlandse diervoederketen.

De verwerking van de bijproducten wordt door de NVWA onderscheiden in een aantal categorieën, te weten:

- Handel en verwerking van plantaardige producten, niet-voeder, gewassen, eerste fase;

- Handel en verwerking van plantaardige producten, tweede fase;

- Verwerking van voormalige voedingsmiddelen (plantaardig);

- Verwerking van dierlijke producten, eerste fase;

- Verwerking van dierlijke producten, tweede fase;

- Verwerking van dierlijke retourstromen (voormalige levensmiddelen);

- Verwerking (verwaarding) van overige bijproducten tot voedermiddelen.

Binnen elke categorie valt ook de import (zowel vanuit EU als derde landen) van de betreffende producten. Elk van deze categorieën wordt hieronder kort toegelicht.

\subsubsection{Handel en verwerking plantaardige, niet-voeder, gewassen, $1^{\mathbf{e}}$ fase}

In de huidige categorie vallen zowel de import (zowel vanuit EU als derde landen) als de eerste verwerking van plantaardige gewassen (granen, groenten en fruit, aardappelen, suikerhoudende gewassen, en oliehoudende zaden) voor (niet-voeder) toepassingen, maar waarvan de rest- of bijproducten de diervoederindustrie ingaan (zoals bijvoorbeeld veekoeken die ontstaan bij de verwerking van oliehoudende zaden). Ook valt hieronder de plantaardige producten die in eerste instantie door akkerbouwers worden geteeld voor humane consumptie, maar wanneer de prijs en/of de kwaliteit tegenvalt worden afgezet in de diervoederketen. Deze sub-keten is afgebakend tot de eerste fase van verwerking van plantaardige producten. Daaronder wordt verstaan:

- Verwerking van granen:

- schonen, pletten, malen of mouten

- winnen van zetmeel uit tarwe en maïs

- Verwerking van oliehoudende zaden:

- winning van ruwe olie

- Verwerking van aardappelen:

- Verwerking tot tafelaardappelen, frites, chips, aardappelmeel, aardappelzetmeel en andere producten

- Verwerking van suikerbieten en cichorei:

- Verwerking tot kristalsuiker en inuline

- Verwerken van groenten en fruit:

- Verwerking tot sappen, conserven en diepvriesproducten

- Winning van zetmeel uit peulvruchten (erwten)

- Bewerking tot product voor verse consumptie: bewaring op akkerbouwbedrijf (o.a. uien, winterpeen), uitselecteren van producten met slechte kwaliteit, diverse bewerkingen (wassen, schonen, schillen, etc.), verpakken. 
Onderstaande tabellen geven een overzicht van de hoeveelheid bijproducten die in Nederland vervoederd worden.

Tabel 1 Bijproducten van granen die in Nederland vervoederd zijn in 2014 (Eurostat).

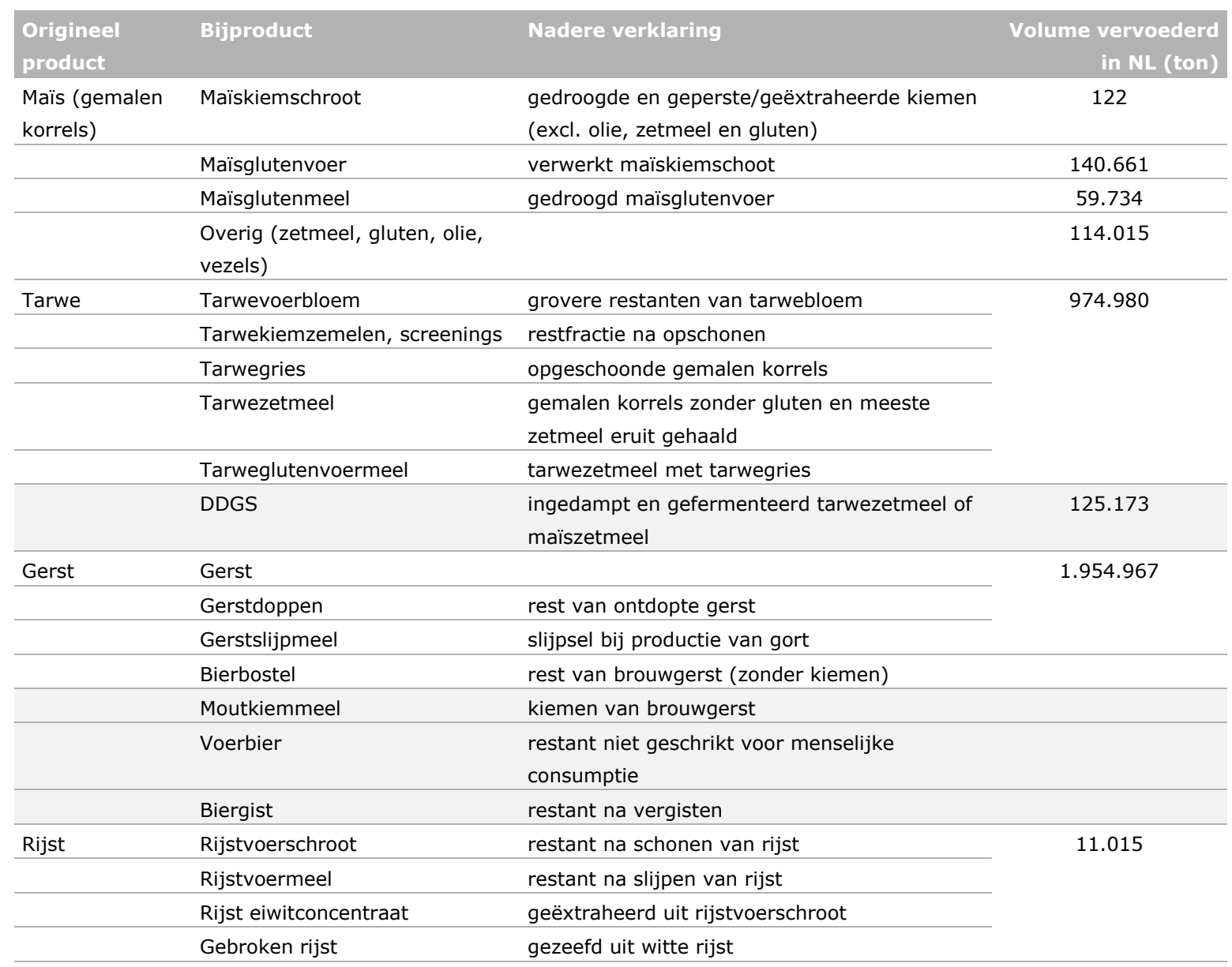

Tabel 2 Bijproducten van groenten en fruit die in Nederland vervoederd zijn in 2014 (Eurostat).

\begin{tabular}{lllr}
$\begin{array}{l}\text { Origineel } \\
\text { product }\end{array}$ & Bijproduct & Nadere verklaring & \multicolumn{1}{c}{$\begin{array}{l}\text { Volume vervoederd } \\
\text { in NL (ton) }\end{array}$} \\
Erwten & Erwten & in mengvoeder & 48.425 \\
\hline Lupinen & Lupinezaden & in mengvoeder & 28.141 \\
\hline Bonen & Bonen (paardenbonen, & in mengvoeder & 20.885 \\
& $\begin{array}{l}\text { veldbonen, tuinbonen, } \\
\text { voerbonen) }\end{array}$ & & ? \\
\hline Johannesbrood & Johannesbroodpitmeel & in mengvoeder & 293.328 \\
\hline Citrus & Citruspulp & geperste pulp en mengsel van schillen, \\
& & celwanden en pitten van citrusfruit.
\end{tabular}

Tabel 3 Bijproducten van aardappelen en maniok die in Nederland vervoederd zijn in 2014 (Eurostat).

\begin{tabular}{|c|c|c|c|}
\hline $\begin{array}{l}\text { Origineel } \\
\text { product }\end{array}$ & Bijproduct & Nadere verklaring & $\begin{array}{l}\text { Volume vervoederd } \\
\text { in NL (ton) }\end{array}$ \\
\hline \multirow[t]{2}{*}{ Aardappel } & Aardappeleiwit & $\begin{array}{l}\text { gekookt en geraffineerd vruchtwater van } \\
\text { malen van aardappelen }\end{array}$ & 0 \\
\hline & Protapec & $\begin{array}{l}\text { ingedampt vruchtwater van malen van } \\
\text { aardappelen (diksap), gedroogd op sojahullen }\end{array}$ & 0 \\
\hline
\end{tabular}


Tabel 4 Bijproducten van suikerhoudende gewassen die in Nederland vervoederd zijn in 2014 (Eurostat).

\begin{tabular}{|c|c|c|c|}
\hline $\begin{array}{l}\text { Origineel } \\
\text { product }\end{array}$ & Bijproduct & Nadere verklaring & $\begin{array}{r}\text { Volume vervoederd } \\
\text { in NL (ton) }\end{array}$ \\
\hline \multirow[t]{3}{*}{ Suikerbiet } & (Gedroogde) bietenpulp & $\begin{array}{l}\text { (gedroogde) pulp, na extractie van } \\
\text { suikerhoudend sap }\end{array}$ & 616.070 \\
\hline & Melasse, biet & $\begin{array}{l}\text { ca. } 1 / 3 \text { deel van gekristalliseerde suikers uit } \\
\text { ingedampt sap (overige naar } \\
\text { levensmiddelindustrie) }\end{array}$ & 72.303 \\
\hline & Vinasse & $\begin{array}{l}\text { gefermenteerde bietmelasse (alcohol naar } \\
\text { levensmiddelindustrie) }\end{array}$ & 223.451 \\
\hline Suikerriet & Melasse, riet & $\begin{array}{l}\text { deel van gekristalliseerde suikers uit } \\
\text { ingedampt sap (overige naar } \\
\text { levensmiddelindustrie) }\end{array}$ & 255.664 \\
\hline
\end{tabular}

Tabel 5 Bijproducten van oliehoudende zaden die in Nederland vervoederd zijn in 2014 (Eurostat).

\begin{tabular}{|c|c|c|c|}
\hline $\begin{array}{l}\text { Origineel } \\
\text { product }\end{array}$ & Bijproduct & Nadere verklaring & $\begin{array}{r}\text { Volume vervoederd } \\
\text { in NL (ton) }\end{array}$ \\
\hline \multirow[t]{3}{*}{ Sojabonen } & Sojaschroot/-schilfers & $\begin{array}{l}\text { toasten en extractie (schroot) of geperst } \\
\text { (schilfers) }\end{array}$ & 6.637 .950 \\
\hline & Sojahullen & restant van onthullen sojabonen & 686.604 \\
\hline & Sojaolie & restant van bewerking ruwe olie & 422.628 \\
\hline Zonnebloempitten & Zonnebloemolie & & 231.234 \\
\hline \multirow[t]{2}{*}{ Kokosnoten } & Kokosschroot/-schilfers & extractie (schroot) of geperst (schilfers) & 5.911 \\
\hline & Kokosvet & & 53.933 \\
\hline \multirow[t]{3}{*}{ Oliepalm } & Palmpitschroot/-schilfers & extractie (schroot) of geperst (schilfers) & 1.310 .985 \\
\hline & Palmpitvetzuurderivaten & & \\
\hline & $(P F A D)$ & uit palmpitolie & 122.539 \\
\hline \multirow[t]{2}{*}{ Koolraapzaden } & $\begin{array}{l}\text { (Kool)raapzaad schroot/- } \\
\text { schilfers }\end{array}$ & extractie (schroot) of geperst (schilfers) & 1.603 .744 \\
\hline & Raapolie & olie geperst uit koolraapzaden & 705.640 \\
\hline \multirow[t]{2}{*}{ Lijnzaden } & Lijnzaad schroot/-schilfers & extractie (schroot) of geperst (schilfers) & 11.063 \\
\hline & Diverse plant, incl. lijnolie & olie geperst uit lijnzaad en overige oliezaden & 56.047 \\
\hline Grondnoten & Grondnotenschroot/-schilfers & extractie (schroot) of geperst (schilfers) & 1.215 \\
\hline Katoenzaden & Katoenzaadschroot/-schilfers & extractie (schroot) of geperst (schilfers) & 0,2 \\
\hline
\end{tabular}

Deze sub-keten begint met de levering van geoogste producten aan verwerkende bedrijven in Nederland. Dit kan direct gebeuren of via diverse stadia van collectie, opslag, overslag en transport. Het product kan in Nederland zijn geteeld of ingevoerd uit andere landen. Daarbij wordt onderscheid gemaakt tussen invoer uit EU-Lidstaten en import uit derde landen, vanwege mogelijke verschillen in aanwezige gevaren door verschillen in agrarische regelgeving en productieomstandigheden.

De sub-keten eindigt met de levering van bijproducten aan diervoederbedrijven (mengvoer- en 'petfood'-bedrijven), veehouders of $2^{\mathrm{e}}$ fase verwerkers. Ook deze levering kan direct gebeuren of via diverse stadia van collectie, opslag, overslag en transport.

\subsubsection{Handel en verwerking plantaardige, niet-voeder gewassen, $\mathbf{2}^{\mathrm{e}}$ fase}

Hoofdproducten uit de eerste fase van verwerking van plantaardige producten worden verder verwerkt tot afgeleide hoofdproducten, die als grondstoffen in uiteenlopende industriële toepassingen (waaronder de voedingsmiddelenindustrie) worden gebruikt. De bijproducten van deze tweede fase verwerking worden onder meer gebruikt als grondstof voor diervoeder. De keten is afgebakend tot de tweede fase van verwerking van plantaardige producten. Daaronder wordt verstaan bijproducten van: 
- Verwerking van zetmeel uit graan, aardappel en peulvruchten

- Productie van zetmeelderivaten

- Raffinage en verwerking van ruwe plantaardige olie tot zuivere plantaardige olie

- Productie van derivaten van plantaardige olie

- Verwerking van gemalen en gemoute granen

- Bakkerij, gebak, etc.

- Brouwerij (bierbostel)

- Verwerking van kristalsuiker en inuline

- Zoetwarenindustrie

- Productie van derivaten van kristalsuiker inulinederivaten

Deze sub-keten van tweede fase verwerkers begint met de levering van grondstoffen voor het verwerkingsproces aan verwerkende bedrijven. De grondstoffen kunnen in Nederland zijn geproduceerd, ingevoerd uit andere lidstaten of geïmporteerd uit derde landen. De levering kan intern gebeuren, binnen één bedrijf dat meerdere fasen van verwerking van plantaardige producten uitvoert. Grondstoffen kunnen ook worden geleverd van een Nederlands bedrijf met eerste-faseverwerking aan een bedrijf met tweede-faseverwerking, mogelijk via diverse stadia van collectie, opslag, overslag en transport. Grondstoffen kunnen ook worden ingevoerd uit lidstaten of geïmporteerd uit derde landen. Tijdens opslag- en overslag kunnen partijen grondstoffen worden gemengd en gesplitst.

De sub-keten eindigt met de levering van bijproducten uit tweede-faseverwerking aan diervoederproducenten (mengvoer- en 'pet food'- bedrijven) en aan dierhouders. Ook deze levering kan direct gebeuren of via diverse stadia van collectie, opslag, overslag en transport.

\subsubsection{Verwerking van plantaardige retourstromen (voormalige voedingsmiddel)}

In deze categorie vallen de uitgesorteerde producten, overschotten en voormalige voedingsmiddelen (VVM) van plantaardige oorsprong, die in de diervoederketen worden afgezet. Het gaat hierbij bijvoorbeeld om retourbrood, koek en deegwaren. In Nederland wordt ca. 200.000 ton VVM verwerkt tot diervoeder (NEVEDI, 2016a). Deze groep bijproducten omvat ook retourproducten die bestaan uit recall- en producten waarvan de houdhaarheidsdatum is overschreden. Het levensmiddel wordt veelal met verpakking gemalen, en de verpakkingsmaterialen worden met mechanische middelen uit de productstroom verwijderd. Voor de aanwezigheid van verpakkingsmateriaal in diervoeder(grondstoffen) geldt een nultolerantie. In de praktijk wordt echter een actiegrens van $0,15 \% \mathrm{w} / \mathrm{w}$ gehanteerd (NVWA, 2015).

\subsubsection{Verwerking van dierlijke producten, $1^{\mathrm{e}}$ fase}

Dierlijke producten worden voortgebracht door de primaire productie, visserij, jacht en natuurbeheer. De definitie van dierlijke producten is volgens de Wet Dieren (artikel 1.1): van dieren afkomstige producten, al dan niet bewerkt of verwerkt, en daarvan afgeleide producten, met inbegrip van levende producten als broedeieren, sperma, eicellen en embryo's. Bij de eerste-faseverwerking van dierlijke producten worden voor menselijke consumptie bestemde producten gescheiden van dierlijke bijproducten, die niet voor menselijke consumptie bestemd zijn. Er zijn wettelijke eisen gesteld aan het gebruik en de verwijdering van dierlijke bijproducten die niet voor menselijke consumptie bestemd zijn, waaronder het gebruik als component van diervoeder (Verordening (EG) nr. 1069/2009, Verordening (EU) nr. 142/2011)). Dierlijke bijproducten zijn ingedeeld in drie categorieën op basis van criteria voor voedselveiligheid en diergezondheid (Verordening (EG) nr. 1069/2009).

De sub-keten eindigt met de levering van verwerkte bijproducten, zoals dierlijk vet en vismeel, aan mengvoerproducenten, pet-foodproducenten en dierhouders. Ook deze overdracht kan direct gebeuren of via diverse stadia van transport, opslag en overslag. 
Tabel 6 Dierlijke producten die in Nederland vervoederd zijn in 2014 (Eurostat).

\begin{tabular}{lllr} 
Origineel product & Bijproduct & Bewerking & $\begin{array}{r}\text { Volume vervoederd } \\
\text { in NL (ton) }\end{array}$ \\
\cline { 1 - 2 } & Weipoeder/WPC & uit gestremde of geprecipiteerde wei & 508.328 \\
\hline & Melkpoeder/-kernen & ingedampte melk & 535.896 \\
\hline landdieren (cat. 3) & Dierlijke eiwitten & verenmeel en gehydrolyseerde eiwitten & onbekend \\
\hline & Rundvet & verkleinen, verhitten, scheiding van vet en eiwit & 70.778 \\
\hline & Varkensvet & verkleinen, verhitten, scheiding van vet en eiwit & 110.557 \\
\hline & Pluimveevet & verkleinen, verhitten, scheiding van vet en eiwit & 37.768 \\
\hline vis (cat. 3) & Vismeel & verkleinen, verhitten, scheiding van vet en eiwit & 131.899 \\
\hline & Visolie & koken, persen, vaste stof drogen & 18.416 \\
\hline
\end{tabular}

\subsubsection{Verwerking van dierlijke producten, $2^{\mathrm{e}}$ fase}

Deze sub-keten betreft de verwerking van producten afkomstig uit de eerste-faseverwerking van dierlijke producten. De sub-keten begint met de levering van producten door bedrijven, die eerstefaseverwerking van dierlijke producten uitvoeren, zoals huiden, darmen, vetweefsel, beenderen, bloed en vlees- en visresten. De grondstoffen kunnen in Nederland zijn geproduceerd, ingevoerd uit andere lidstaten of geïmporteerd uit derde landen. De levering kan intern gebeuren, binnen één bedrijf dat meerdere fasen van verwerking van dierlijke producten uitvoert. Grondstoffen kunnen ook worden geleverd van een Nederlands bedrijf met eerste fase verwerking aan een bedrijf met tweede fase verwerking, mogelijk via diverse stadia van collectie, opslag, overslag en transport. Een voorbeeld hiervan is sterilisatie onder druk van huiden, karkassen en vet (producten van de eerste fase) voor de vervaardiging van organische meststoffen en bodemverbeteraars, als compost of omgezet in biogas. $\mathrm{Er}$ zijn geen gegevens over de hoeveelheden van producten die vanuit de $2^{\mathrm{e}}$ fase productie gebruikt worden in diervoeders.

In dit rapport zijn de $1^{\mathrm{e}}$ en $2^{\mathrm{e}}$ faseverwerking samengevoegd. De mogelijke aanwezigheid van chemische stoffen in dierlijke bijproducten wordt gezamenlijk behandeld.

\subsubsection{Verwerking van dierlijke retourstromen (voormalige levensmiddelen)}

In deze sub-keten gaat het om vlees en vleeswaren waarvan de houdbaarheidsdatum is overschreden. Er zijn geen gegevens bekend over volumes. Dergelijke producten mogen echter niet gebruikt worden in diervoeder voor voedselproducerende dieren en worden dus in dit rapport verder niet behandeld.

\subsubsection{Verwerking ("verwaarding") van overige bijproducten tot voedermiddelen} De technologie voor gebruik van bijproducten is sterk in ontwikkeling door de vergrote aandacht voor circulaire economie (Kiser et al., 2016). Daarmee verandert ook het scala van producten die voor diervoeder beschikbaar zijn. Sommige bijproducten die tot voor kort alleen in diervoeder werden toegepast, worden nu ook gebruikt voor verwerking tot brandstof of extractie van eiwitten, zoals bierbostel, en bietenpulp. Er is daardoor minder product beschikbaar voor verwerking tot diervoeder. Andersom kunnen producten, die tot voor kort alleen voor co-vergisting werden gebruikt, nu ook geschikt worden gemaakt voor gebruik in diervoeder. Zo kan bermgras als grondstof dienen voor grasraffinage met winning van eiwit voor industrie en vezels voor papier/karton. Het resterend sap van grasraffinage is vervolgens bestemd voor diervoeder.

Uit het Landelijk AfvalbeheerPlan (LAP) 3 blijkt dat dierlijke bijproducten en bewerkte dierlijke bijproducten, zoals diermeel, afvalstoffen zijn (Ministerie van Infrastructuur en Waterstaat, 2017) en dus niet gebruikt mogen worden voor diervoeder. Ze mogen wel gebruikt worden voor petfood. Op het moment dat een bij- of restproduct de bestemming "diervoeder" krijgt binnen de kaders van de wetgeving, zoals veiligheid (EC 178/2002), in plaats van de situatie dat een eigenaar zich "ontdoet" van het materiaal, wordt het niet meer beschouwd als afval.

$\mathrm{Bij}$ het opslaan en verbranden van diermeel blijft sprake van een afvalstof. Bijvoorbeeld, biodiesel verkregen na chemische omzetting van dierlijk vet dat voldoet aan de hiervoor geldende kwaliteitseisen en dat ingezet wordt als brandstof, is geen afvalstof meer. Gescheiden ingezameld organisch afval (swill) wordt na inzameling afgevoerd naar een composteer- of vergistingsinstallatie 
voor verwerking tot compost. Verwerking van swill tot diervoeder is verboden, met uitzondering van toepassing van swill in petfood (Verordening (EG) nr. 1069/2009).

Verordening (EC) 178/2002 legaliseert alle reststromen die voldoen aan de eisen van veiligheid en hygiëne, wat vertaald kan worden naar tenminste alle voedermiddelen zoals vermeldt in de Catalogus van voedermiddelen (Verordening (EC) 68/2013). Verboden zijn de materialen zoals genoemd in Appendix III van (EC) 767/2009 en de bijproducten volgens de bepalingen in (EC) 1069/2009.

\subsubsection{Additieven}

Additieven of toevoegingsmiddelen zijn stoffen, micro-organismen of preparaten die geen voedermiddelen noch voormengsels zijn, en die opzettelijk aan diervoeder of water worden toegevoegd (Verordening (EG) nr. 1831/2003) o.a. met het oog op het gunstig beïnvloeden van het diervoeder e/o het dierlijke product. Spoorelementen, enzymen en aminozuren zijn voorbeelden van diervoederadditieven.

In Nederland zijn slechts enkele bedrijven actief in het produceren van additieven. Veel van de in Nederland gebruikte additieven worden geproduceerd in EU-lidstaten of derde landen en in Nederland geïmporteerd. Enzymen, vitamines en probiotica komen grotendeels uit Zuidoost-Azië. De additieven verschillen van aard en eigenschappen. Er zijn additieven die de eigenschappen van diervoeders voor dieren of dierlijke producten gunstig beïnvloeden, of die voldoen aan de voedingsbehoefte van de dieren. Ook zijn er additieven die het makkelijker maken om bijzondere voedingsdoelen te bereiken, of die de hinder veroorzaakt door dierlijke uitwerpselen voorkomen of beperken of de leefomgeving van de dieren verbeteren. De productieprocessen zijn ook verschillend. Het kan bijvoorbeeld gaan om synthese van verbindingen, het bewerken van producten uit de mijnbouw (binnen en buiten de EU) om deze geschikt te maken voor toepassing in de mengvoederindustrie of het winnen van kleurstoffen uit plantaardige producten. Veelal komen er chemische processen aan te pas, maar additieven kunnen ook geproduceerd worden door (GGO-)micro-organismen, zoals vitamines en enzymen. De afnemers van de additieven zijn de producenten van mengvoeders, aanvullende voeders en voormengsels, maar ook veehouders (van der Roest J., 2004).

\subsubsection{Productie van mengvoeder (incl. visvoer)}

Mengvoeders worden gedefinieerd in Verordening (EG) nr. 767/2009 als 'mengsels van ten minste twee voedermiddelen, met of zonder toevoegingsmiddelen, bestemd voor orale vervoedering in de vorm van volledige diervoeders of aanvullende diervoeders'. Onder de term mengvoeders vallen aanvullende voeders, volledige voeders, dieetvoeders, gemedicineerde diervoeders en kunstmelkvoeders. Voor een goede verwerking en gelijkmatige verdeling van additieven in mengvoeders kan gebruik gemaakt worden van voormengsels. Voor voedermiddelen en mengvoeders (als ook voor voormengsels, aanvullende diervoeders etc.) zijn maximumgehalten (ML's) en actiedrempels (AD's) voor ongewenste stoffen vastgelegd in de bijlagen van Richtlijn 2002/32/EG. In een mengvoederfabriek komen verschillende stromen van grondstoffen en additieven bij elkaar. De grondstoffen zijn opgeslagen in bijvoorbeeld silo's en worden van daaruit getransporteerd naar de productieruimten. De dosering van de verschillende grondstoffen verloopt vaak computergestuurd. De juiste verhoudingen van grondstoffen en additieven is belangrijk en verschillen per diersoort. De grondstoffen worden bewerkt (bijvoorbeeld gemalen of kapot geslagen met behulp van een hamermolen) en gemengd. Verschillende bestanddelen worden in een bepaalde volgorde toegevoegd en, indien nodig, geperst of geëxtrudeerd zodat er een voormengsel of mengvoeder van de gewenste samenstelling en vorm ontstaat. Het mengsel wordt, na eventueel verpakt te zijn, opgeslagen en getransporteerd.

In de procesapparatuur en de buizen en leidingen tussen de verschillende processtappen kunnen productresten achterblijven waarmee kruisbesmetting (versleping) tussen producten kan ontstaan. Vaak is een goede reiniging alleen mogelijk als de productie geheel stilgelegd wordt en nat reinigen is vaak niet mogelijk. Doordat reiniging droog uitgevoerd wordt (blazen) en er gebruikgemaakt wordt van spoelcharges worden er geen specifieke reinigingsmiddelen gebruikt die in diervoeder terecht kunnen komen. Het is dus belangrijk om de volgorde van diervoeders die op dezelfde lijn geproduceerd worden te bepalen, omdat kruisbesmetting niet te voorkomen is (Vis et al., 2003). 


\subsubsection{Samenstelling diervoeder}

Herkauwers worden gevoerd met ruwvoer en krachtvoer en eventueel voedermiddelen. Ruwvoer zijn gewassen als gras, stro, knollen en snijmaïs die direct van het land of na een eenvoudige bewerking aan de dieren gevoerd worden. In de mengvoerwagen wordt ruwvoer vaak vermengd met voedermiddelen of aanvullende diervoeders. Voedermiddelen bestaan uit granen en peulvruchten of uit bijproducten vanuit de levensmiddelenindustrie, zoals sojaschroot, die niet geschikt zijn voor humane consumptie (NEVEDI, 2016b). In 2014 werd er wereldwijd 964 miljoen ton mengvoeders geproduceerd. China en de Verenigde Staten zijn hierbij wereldleiders met respectievelijk 183 en 172 miljoen ton productie. In de EU werd in 2014153 miljoen ton geproduceerd, waarvan het aandeel het hoogste was in Duitsland, Frankrijk en Spanje (met een productie van, respectievelijk, 24, 21 en 21 miljoen ton). In Nederland werd in 2015 ca. 12,4 miljoen ton mengvoeders geproduceerd (bron: website Nevedi).

Varkens en pluimvee worden vaak gevoerd met volledige voeders (mengvoer) en brijvoeders. De samenstelling van diervoeder varieert afhankelijk van prijs en beschikbaarheid. Granen zoals tarwe, gerst, haver en maïs zijn vanwege hun voedingswaarde zeer geschikt voor landbouwhuisdieren en meer dan de helft (54\%) van het mengvoeder bestaat uit granen (NEVEDI, 2016a). Verder bevat mengvoeder oliehoudende zaden (13\%) en sojaproducten (11\%) en bijproducten van de aardappelen suikerindustrie, peulvruchten, retourproducten en voormengsels (NEVEDI, 2016b). Maïsglutenmeel en Dried Distiller Grains and Solubles (DDGS) worden bijna niet meer geïmporteerd. Deze ingrediënten komen voornamelijk uit de VS en import is sinds 2007 afgenomen door asynchrone toelating van GGO-gewassen. Door de toegenomen biodieselproductie is het aandeel raapzaadschroot significant toegenomen (FEFAC, 2015). De verdeling van grondstoffen naar diersoort is weergegeven in Figuren 3 en 4.

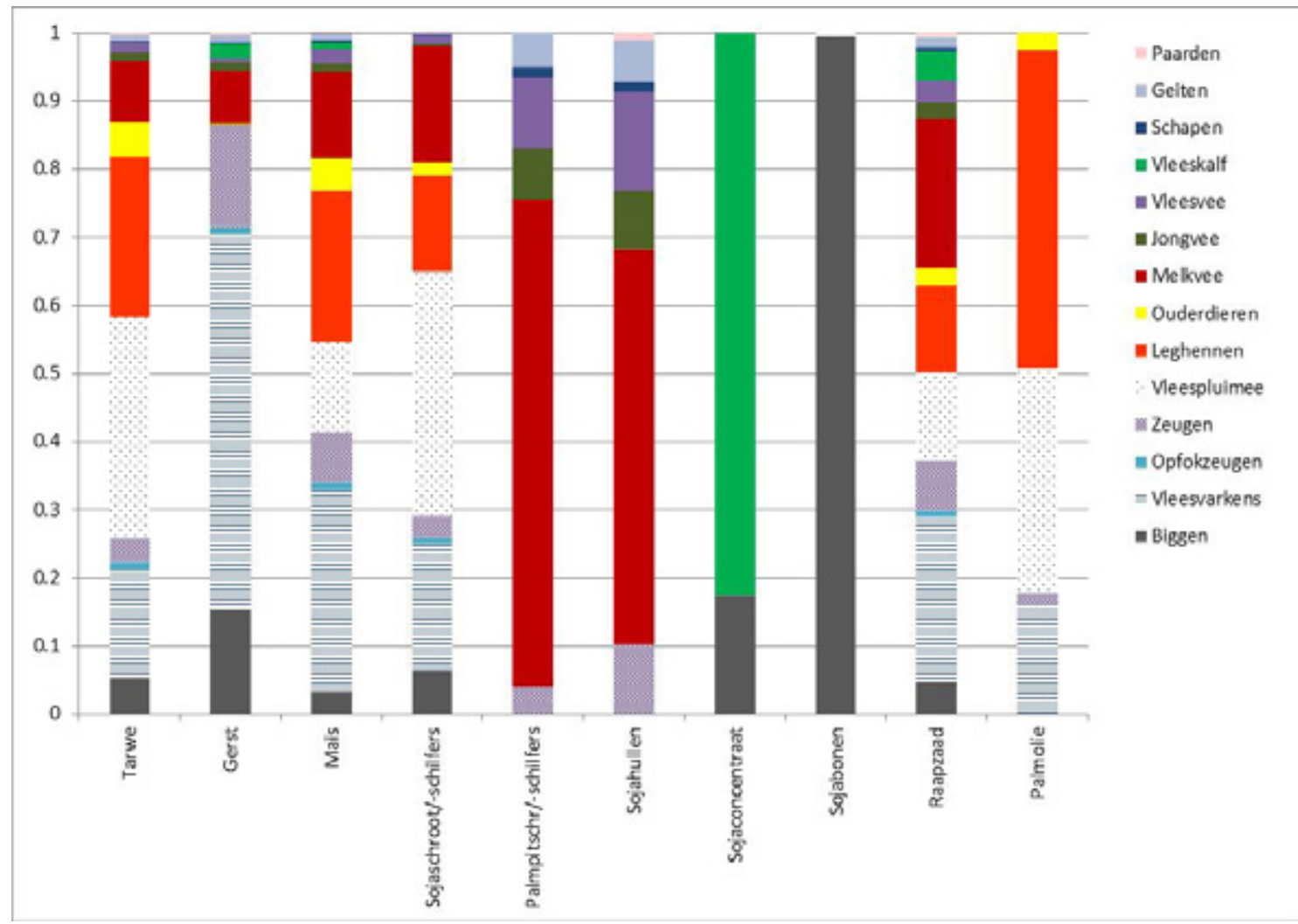

Figuur 3 Distributie van grondstoffen naar verschillende diersoorten (2014). Alleen top 10 geïmporteerde en in Nederland geproduceerde grondstoffen (op basis van tonnage in 2014) is weergeven. N.B. dit is een dynamisch geheel met mogelijke variatie over de jaren heen door bijvoorbeeld schaarste van een grondstof (van der Fels-Klerx et al., 2017). 


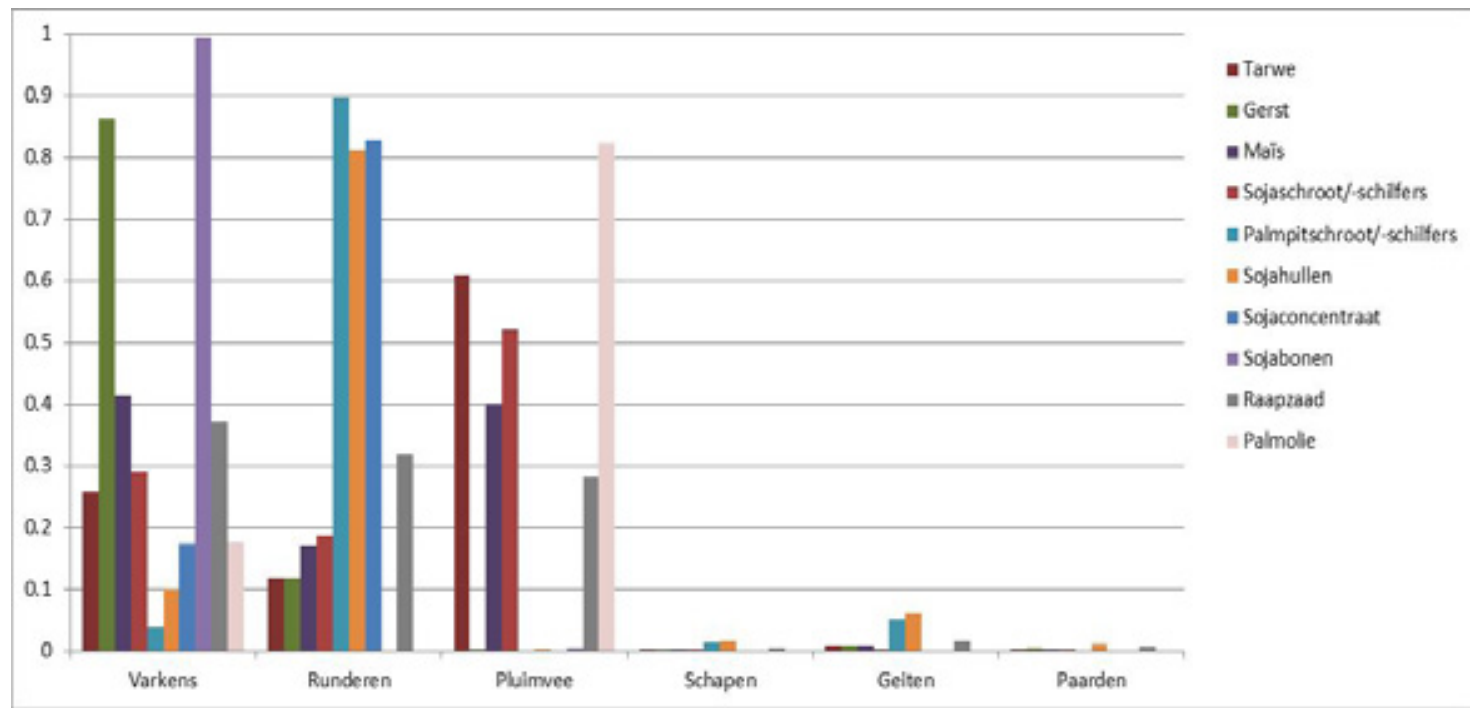

Figuur 4 Verdeling van top 10 grondstoffen per diersoort (op basis van tonnage in 2014). Varkens omvat zowel biggen als volwassen dieren, runderen zowel kalven als melk- en vleesrunderen en pluimvee zowel vleespluimvee als leghennen. N.B. dit is een dynamisch geheel met mogelijke variatie over de jaar heen door bijvoorbeeld schaarste van een grondstof (van der Fels-Klerx et al., 2017).

\subsubsection{Import}

In Nederland wordt jaarlijks ongeveer 38 miljoen ton aan grondstoffen ingevoerd (Eurostat, 2016). Hiervan wordt $2 / 3^{e}$ deel doorgevoerd en $1 / 3^{e}$ deel gebruikt in eigen land (NVWA, persoonlijke communicatie). Grondstoffen bestemd voor Nederlandse mengvoederproducenten kunnen via havens van andere EU-lidstaten uit derde landen in de EU ingevoerd worden, bijvoorbeeld via de haven van Antwerpen of Hamburg. De lidstaat waar de voedermiddelen binnenkomen, dient de importcontrole uit te voeren, ook als de producten voor een andere lidstaat bestemd zijn. Er is echter weinig informatie over de mate waarin grondstoffen via een ander Europees land de EU binnenkomen.

Figuur 5 geeft de import van diverse grondstoffen weer ten opzichte van de eigen productie in Nederland. Nederland is voor granen, schroten/schilfers, oliezaden en daarvan afgeleide producten afhankelijk van de import. Granen komen grotendeels uit Frankrijk en Duitsland en Oekraïne (mais), terwijl Brazilië, Argentinië en de Verenigde Staten zorgen voor de levering van sojaproducten. Raapzaad en zonnebloempitten komen zowel uit Frankrijk en Duitsland als uit Oost-Europese landen zoals Bulgarije, Litouwen, Roemenië en Oekraïne naar Nederland. Palmpitschrot/-schilfers, palmolie en palmpitvetten zijn afkomstig uit Indonesië en Maleisië. De grootste hoeveelheden peulvruchten komen uit Duitsland, Oekraïne, China en Australië. 


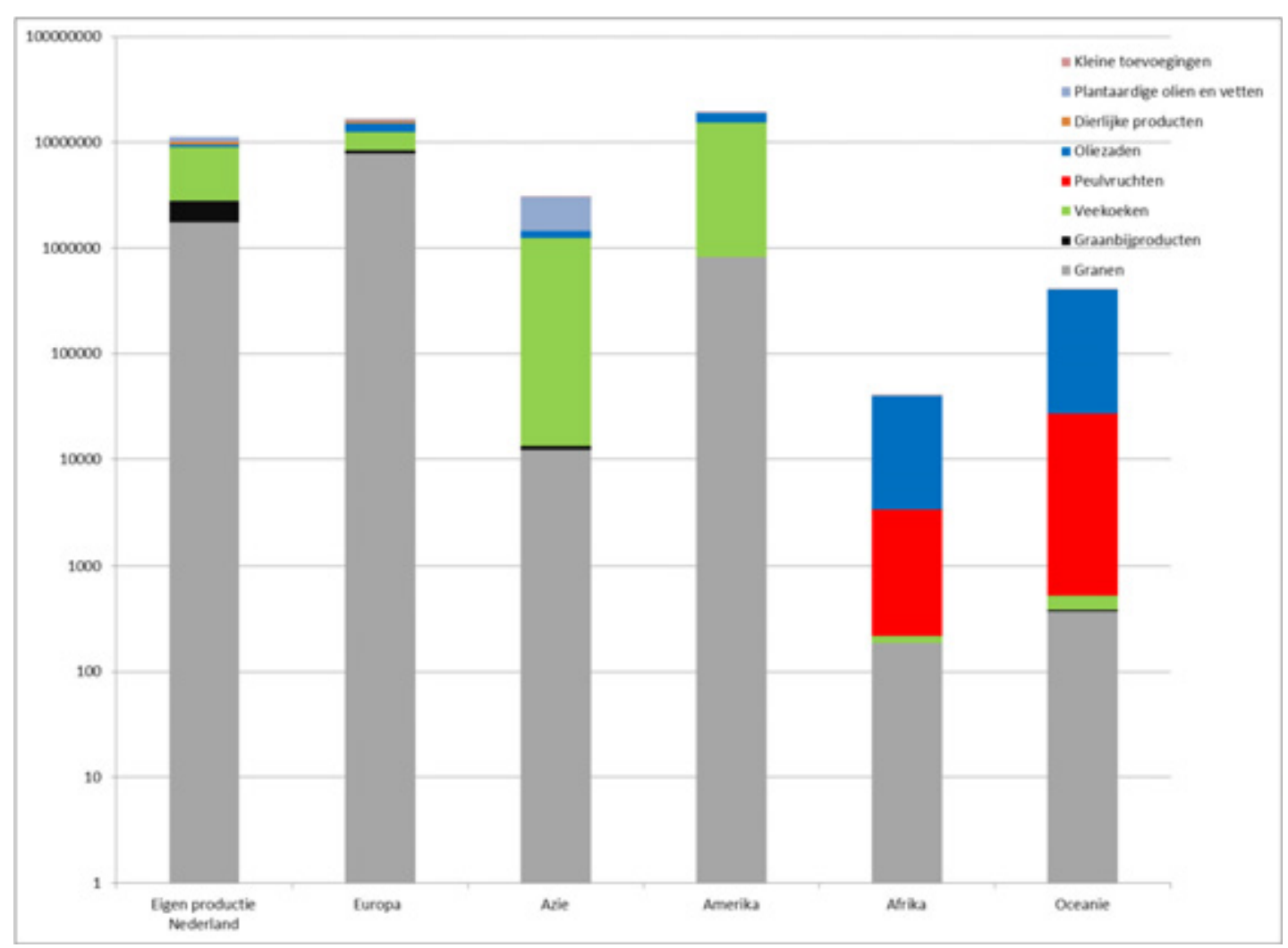

Figuur 5 Import van diverse grondstoffen uit verschillende werelddelen en eigen Nederlandse productie in ton (jaar 2014). N.B. weergave op log schaal (van der Fels-Klerx et al., 2017).

Grondstoffen die in de grootste hoeveelheden worden geïmporteerd betreffen sojaproducten (sojabonen, -schroot, -concentraat) en maïs. Daarnaast wordt er in Nederland veel gerst, tarwe en raapzaad ingevoerd uit Europese landen. Voor sommige producten, zoals soja, geldt dat deze ook zonder verdere ver- of bewerking doorgevoerd kunnen worden naar andere Europese landen. Daarnaast worden sommige geïmporteerde grondstoffen in Nederland verwerkt tot bijvoorbeeld oliën, waarvan een deel ook weer geëxporteerd wordt.

Tabel 7 geeft, op basis van de totale levering van diervoeder grondstoffen aan Nederland, de top 10 van import- en invoerlanden weer. Een aantal landen, zoals Duitsland en Frankrijk, levert meerdere grondstoffen in grote hoeveelheden, terwijl vanuit bijvoorbeeld Brazilië, Argentinië en Indonesië hoofdzakelijk één grondstof naar Nederland komt. In Tabel 7 is geen rekening gehouden met mogelijke herlabelling van grondstoffen. Zo vermeldt de tabel palmpitschroot/schilfers bij herkomstland Duitsland, maar deze worden in Maleisië en Indonesië geproduceerd, en dan import naar Duitsland de EU binnengebracht. Er zijn echter geen gegevens over mogelijke herlabelling van grondstoffen bij import in Europa. 
Tabel 7 Top 10 landen die grondstoffen voor diervoeder aan Nederland leveren op basis van totale hoeveelheid alle grondstoffen in ton (\% import 2014). N.B. Import- of invoerland is niet altijd gelijk aan productieland (SecureFeed, CBS, MVO 2014).

\begin{tabular}{|c|c|c|}
\hline Land & Import ton $(\%)$ & Grondstoffen \\
\hline Brazilië & $12.556 .695(32,2 \%)$ & Maïs, soja (schroot/schilfers, bonen, concentraat*), citruspulp \\
\hline Duitsland & $6.183 .572(15,9 \%)$ & $\begin{array}{l}\text { Granen (o.a. tarwe, gerst, maïs, rogge) en graanbijproducten, soja } \\
\text { (schroot/schilfers, hullen concentraat, bonen), zonnebloemschroot/ } \\
\text { schilfers/pitten, palmpitschroot/schilfers, raapzaadschroot/schilfers*, } \\
\text { maïsglutenvoer, peulvruchten (erwten, lupinen, bonen), oliezaden (o.a. } \\
\text { raapzaad, lijnzaad, bietenpulp, gras, citruspulp, riet, vinasse, melasse), } \\
\text { dierlijke producten (o.a. weipoeder, melkpoeder, rund-, varken- en } \\
\text { pluimveevet, vismeel), plantaardige olie (o.a. raapolie, palmpitvet, } \\
\text { mengsels) }\end{array}$ \\
\hline Argentinië & $4.350 .619(11,2 \%)$ & $\begin{array}{l}\text { Maïs, soja (schroot/schilfers*, hullen, concentraat), } \\
\text { zonnebloemschroot/schilfers ne -pitten, erwten, bonen, citruspulp }\end{array}$ \\
\hline Oekraïne & $1.727 .211(4,5 \%)$ & $\begin{array}{l}\text { Granen (maïs*, tarwe, boekweit), zonnebloemschroot/schilfers, -pitten, } \\
\text { erwten, raapzaad, sojabonen, raapolie }\end{array}$ \\
\hline Indonesië & $1.696 .612(4,4 \%)$ & $\begin{array}{l}\text { Kokosschroot/schilfers, palmpitschroot/schilfers, palmolie, } \\
\text { palmpitvet*, melasse riet, kokosvet, mengsels }\end{array}$ \\
\hline België/Luxemburg & $1.509 .382(3,9 \%)$ & $\begin{array}{l}\text { Granen (o.a. tarwe, gerst, maïs, triticale, rogge, haver), } \\
\text { graanbijproducten, raapzaadschroot/schilfers*, sojaschroot/schilfers,- } \\
\text { concentraat, -hullen, palmpitschroot/schilfers, maïsglutenvoer, } \\
\text { maïsglutenmeel, erwten, sojabonen, raapzaad, lijnzaad, } \\
\text { zonnebloempitten, bietenpulp, vinasse, melasse, dierlijke producten (o.a. } \\
\text { weipoeder, melkpoeder, dierlijke vetten), diverse plantaardige oliën (o.a. } \\
\text { raapolie) }\end{array}$ \\
\hline Verenigde Staten & $1.141 .089(2,9 \%)$ & Maïs, erwten, sojabonen*, citruspulp, melasse riet \\
\hline Maleisië & $919.064(2,4 \%)$ & Palmpitschroot/schilfers, palmolie*, palmpitvet, mengsels \\
\hline Roemenië & $611.068(1,6 \%)$ & Granen (maïs*, tarwe, gerst), raapzaad, zonnebloempitten \\
\hline
\end{tabular}

\footnotetext{
* hoogste bijdrage import cijfers (tonnage)
} 


\subsection{Chemische gevaren}

De diervoederketen vormt een complex geheel door de vele schakels in de keten. Tijdens de handel worden partijen samengevoegd (blending) of gesplitst. De handel gaat vaak over meerdere landen. Gevaren kunnen van nature aanwezig zijn in de grondstoffen of geïntroduceerd worden op diverse plekken in de keten. In de volgende paragrafen worden de mogelijke chemische gevaren in de diervoederketen beschreven. Van deze gevaren wordt in deze paragraaf kort een algemene beschrijving gegeven. Daarnaast worden de bronnen van introductie van gevaren in de diervoederketen aangegeven, en de mogelijke aanwezigheid in de verschillende sub-ketens en relevante regelgeving benoemd.

\subsubsection{Dioxines en PCB's}

\subsubsection{Algemeen}

Dioxines is een verzamelnaam voor gechloreerde dibenzo-p-dioxines (PCDD) en dibenzofuranen (PCDF). Hoewel er 210 potentiële congeneren zijn, wordt in praktijk alleen gekeken naar de 17 congeneren met 4 tot 8 chlooratomen waarbij in elk geval de 2, 3, 7 en 8-posities in het molecuul bezet zijn. Dit heeft deels te maken met de toxiciteit maar met name met de persistentie. Congeneren met chlooratomen op deze posities zijn relatief slecht afbreekbaar, lipofiel en accumuleren in vet of vetrijke producten als melk en eieren. De meest toxische dioxines zijn 2,3,7,8-tetrachloordibenzo-pdioxine (TCDD) en 1,2,3,7,8-pentachloordibenzo-p-dioxine (PCDD). De relatieve toxiciteit van elke congeneer wordt uitgedrukt met behulp van zogenaamde TEF-factoren, die aangeven of een congeneer ruwweg 3,10, 30, 100 of 3000 keer minder toxisch is dan TCDD. Dit resulteert in TEF waarden van $1,0,3,0,1,0,03,0,01$ en 0,0003. Bij de analyse worden de absolute gehalten vermenigvuldigd met de specifieke TEF waarden waarna de resultaten worden opgeteld tot een zogenaamd TEQ-gehalte. Meestal dragen de lager gechloreerde dioxines het meeste bij aan het TEQgehalte maar er zijn besmettingsbronnen waarbij dit niet zo is.

Naast de dioxines zijn er ook 12 zogenaamde dioxineachtige polychloorbifenylen (PCB's), die soortgelijke toxische effecten als dioxines kunnen veroorzaken. Ook deze dioxine-achtige (dioxin-like, dl-)PCB's hebben een TEF-waarde gekregen, variërend van 0,1 voor PCB 126 tot 0,00003 voor acht zogenaamde mono-ortho PCB's. In praktijk draagt PCB 126 het meeste bij aan het TEQ-gehalte. De overige PCB's worden vaak niet-dioxineachtige (non-dioxin-like of ndl-) PCB's genoemd. Een aantal van deze ndl-PCB's wordt al gedurende een lange tijd geanalyseerd, waarbij op basis van verschillende mengsels gekozen is voor 7 zogenaamde indicator-PCB's $(28,52,101,118,138,153$ en 180) voor de groep van ndl-PCB's. Omdat PCB 118 een dl-PCB is, heeft de EU bij de normstelling uiteindelijk gekozen voor de 6 overige ndl-PCB's (Richtlijn 2002/32/EG).

\section{Bronnen}

Dioxines kunnen als verontreiniging voorkomen in chloorbevattende chemicaliën zoals PCB's en chloorfenolen, maar kunnen ook ontstaan bij verbranding van chloorhoudend afval zoals PVC. Dat laatste betekent dat dioxines terecht kunnen komen in diervoedergrondstoffen die direct zijn gedroogd met ongeschikte brandstoffen, zoals plastic afval of geverfd hout (Liem et al., 1991). Dat laatste geldt ook wanneer olie wordt gebruikt dat is verontreinigd met PCB-olie (wat bijvoorbeeld het geval was bij een incident in 2008 in Ierland) (Heres et al., 2010; Marnane, 2012; Tlustos et al., 2012).

In het verleden werd PCB-olie gebruikt in onder andere transformatoren en in silo's om de inhoud te verwarmen en vloeibaar te houden. Door lekkage heeft dit tot twee grote incidenten met besmette rijstolie geleid (Hsu et al., 1985; Kuratsune et al., 1972). In 1999 bleek in België 60 ton gerecycled diervoedervet besmet met zo'n 200 kg PCB's waarvan de bron nooit is ontdekt (Bernard et al., 1999; Traag et al., 2006); (van Larebeke et al., 2001). Chloorfenolen zijn veel gebruikt als bestrijdingsmiddel waaronder als fungicide. Dat laatste geldt met name voor pentachloorfenol dat veel gebruikt is voor houtverduurzaming. Dat betekent dat oud hout, al dan niet verwerkt tot zaagsel, besmet kan zijn met dioxines, met name met hoog gechloreerde congeneren. In 2010 bleken vetzuren in Duitsland besmet met tetrachloorfenolen en de daarmee samenhangende dioxines (Abraham et al., 2011). Het betrof hier technisch vet dat vermengd was met diervoeder. Het technische vet was afkomstig uit de biodieselproductie, waarbij voor de verhitting met chloorfenolen behandeld hout werd gebruikt om te verbranden. Hieruit kunnen dioxines ontstaan. 
Dioxines kunnen ook in hoge gehalten voorkomen in bepaalde kleisoorten (bijvoorbeeld kaolien, Mississippi ball clay); de dioxines zijn in een ver verleden ontstaan onder invloed van hoge druk en temperatuur. Klei wordt in diervoeders gebruikt als antiklontermiddel en voor inmenging van vitamines en mineralen. Ook via andere industrieën kunnen deze kleisoorten in diervoeder terecht komen (Jobst and Aldag, 2000). In 2004 werd in Nederland PCDD in de melk van koeien ontdekt. De bron bleek de kaoliniet, die gebruikt was om aardappelen te sorteren en via de aardappelschillen gebruikt als voer in de koe terecht waren gekomen (Hoogenboom et al., 2010). Een speciaal geval was het incident met diervoedervet afkomstig uit de gelatineproductie in 2006 . Hierbij bleek zoutzuur, gebruikt in de gelatineproductie, de bron van de dioxine besmetting maar de exacte oorzaak van de aanwezigheid van PCDD in het zoutzuur is nooit duidelijk geworden (Hoogenboom et al., 2007). Vis uit bepaalde regio's, zoals de Baltische zee, blijkt relatief hoge gehalten aan dioxines en PCB's te bevatten. Dat betekent dat ook vismeel en visolie bereid uit die vis relatief hoge gehalten kan bevatten. Visolie kan via speciale procedés (actieve kool en stoomdestillatie) worden opgeschoond (Maes and De Meulenaer, 2005).

\subsubsection{Aanwezigheid dioxines en PCB's in sub-ketens}

De RASFF-databank geeft 200 meldingen voor dioxines en dl-PCB's in diervoeder in de periode 20052015. Het betreft hier een brede range aan ingrediënten en producten, maar de voornaamste zijn spoorelementen (additieven zoals kopersulfaat en zinkoxide), vet(zuren) en oliën van plantaardige oorsprong (zoals palmpitvetzuren) en vismeel. Plantaardige olie kan van nature lage concentraties dioxines bevatten. Door raffinage komen de dioxines vooral in het destillaat, waardoor de concentraties hierin toenemen.

Recentelijk hebben Adamse et al. (2015) resultaten van de nationale monitoring van diervoeder grondstoffen op aanwezigheid van dioxinen en dl-PCB's geanalyseerd (Adamse et al., 2015). Het beschreven onderzoek betrof een evaluatie van monitoringsgegevens van de periode 2001-2011, met in totaal 4938 monster resultaten (NP diervoeders en private data), waarvan 40 de ML overschreden en 81 de AL. Het percentage monsters met een overschrijding van de wettelijke maximale gehalten voor ofwel dioxinen, dan wel dioxinen en dl-PCB's, was lager dan $1 \%$ voor de meeste categorieën diervoedergrondstoffen, behalve voor vismeel (10 monsters, 4,1\%), kleimineralen (binders en antiklontermiddelen) (11 monsters, 3,4\%) en plantaardige oliën en bijproducten ( 7 monsters, 1,7\%). Het percentage monsters dat niet voldeed aan de actiedrempel was drie maal hoger dan het percentage monsters boven de wettelijke limiet (de actiedrempel ligt circa 33\% lager ligt dan de ML). De actielimiet werd overschreden in iets meer dan $1 \%$ van de monsters dierlijk vet, voormengsels en ingrediënten van plantaardige herkomst (zonder de groep niet-dierlijke oliën). De actiedrempels voor de categorieën vismeel, kleimineralen en plantaardige oliën en bijproducten werden in, respectievelijk, $5,0 \%, 9,8 \%$ en $3,0 \%$ van de gevallen (monsters) overschreden.

In het NP Diervoeder werden voor de periode 2011-2016 incidenteel overschrijdingen gevonden in visproducten, kleimineralen, kokosolie en premix.

a. Primaire plantaardige productie

De opname door planten van dioxines en PCB's in de bodem is minimaal. Met name depositie van opspattende grond of atmosferische depositie zorgt voor dioxines en PCB's op gras. Risicovolle gebieden zijn de uiterwaarden, waar hoge concentraties PCB's aangetroffen zijn, en waar vleesrunderen en schapen kunnen grazen. In de winterperiode zijn de dioxinegehalte in het gras hoger, dit is van belang voor dieren die het gehele jaar buiten staan.

b. Invoer, import en verwerking plantaardige producten niet voedergewassen, $1^{\mathrm{e}}$ fase De aanwezigheid van zware industrie of afvalverwerking leidt tot milieuvervuiling door dioxines en PCB's (Diletti et al., 2008). In producten die uit dergelijke gebieden geïmporteerd worden zijn de gehalten van dioxines en PCB's hoger.

c. Verwerking plantaardige producten, 2e fase

Door verwerking van plantaardige gewassen, bijvoorbeeld door actieve drogingsprocessen zoals de toevoeging van actief kalk of door middel van directe droging via verbranding van bewerkt hout, kunnen dioxines en PCB's in de voedergewassen terecht komen. Dit kan nogal eens voorkomen bij producten uit de Oekraïne (Persoonlijke communicatie Hoogenboom, 2017). 
Verwerking van granen tot broodmeel (drogingsprocessen) kan leiden tot hoge concentraties dioxines en PCB's. Wanneer oud brood verwerkt wordt tot diervoeder wordt het eerst gedroogd. Als hiervoor verkeerde brandstof of technieken gebruikt worden (als de producten in de oven bijvoorbeeld in direct contact komen met rook), dan kan het meel verhoogde concentraties dioxines en PCB's bevatten. In Ierland zijn hier twee incidenten uit voortgekomen. Bij deze incidenten bleek PCB-rijke olie gebruikt te zijn bij het drogingsproces. Bij de verwerking van citruspulp tot diervoeder wordt citruspulp met ongebluste kalk gemengd. Ook dit heeft in het verleden tot vervuiling met dioxines en PCB's geleid. De gebruikte kalk was afkomstig van de industriële productie van PVC en bevatte hoge concentraties dioxines (Malisch and Kotz, 2014).

d. Verwerking plantaardige reststromen (voormalige levensmiddelen)

Retourstromen bevatten naar verwachting weinig tot geen dioxines en PCB's, behalve wanneer tijdens de eerdere drogingsprocessen vervuiling heeft plaatsgevonden. Bij het drogen van retourstromen of andere bijproducten is het altijd van belang op te letten welke brandstof er gebruikt is.

e. Verwerking dierlijke producten, $1^{\mathrm{e}}$ en $2^{\mathrm{e}}$ fase

Voedermiddelen van maritieme oorsprong kunnen dioxines en PCB's bevatten. In visproducten (vismeel en visolie) afkomstig uit de Baltische Zee zijn hogere concentraties dioxines en PCB's aangetroffen dan in visproducten afkomstig uit andere wateren.

f. Verwerking bijproducten tot voedermiddelen

Bij de verwerking van vervuilde visproducten kunnen ook de bijproducten dioxines en PCB's bevatten. Vis is een mogelijke bron van dioxines en ook bij het drogen kan vervuiling optreden. Schapenlevers bevatten vaak verhoogde concentraties dioxines en PCB's (EFSA, 2011).

\section{g. Chemische productie additieven}

Gerecyclede sporenelementen, zoals koper, kunnen besmet zijn met dioxines en PCB's, het risico hierop is afhankelijk van het land van herkomst. In sommige landen worden koperkabels verhit om koper vrij te krijgen. Bij dit verhittingsproces kunnen dioxines en PCB's gevormd worden.

Daarnaast worden bepaalde kleisoorten zoals kaoliniet, sepioliet en bentoliet gebruikt als antiklontermiddelen en als mycotoxinebinders. Sommige van deze kleisoorten bevatten hoge concentraties dioxines en PCB's. Voor gebruik wordt er dan ook eerst getest op dioxines en PCB's. Bij het gebruik van kelp (een zeewier) als bron van mineralen is er ook een hoger risico op vervuiling met dioxines en PCB's (Ferrario et al., 2003).

h. Productie mengvoeder

De productie van mengvoeder leidt naar verwachting niet tot vervuiling van diervoeder met dioxines of PCB's.

\subsubsection{Overdracht naar dierlijke producten}

Dioxines en PCB's hopen zich op in vetrijke producten, zoals dierlijke vetten, vis, melk en eieren. Dioxines en PCB's accumuleren in het vetweefsel van dieren. De lager gechloreerde dioxines blijken beter opneembaar dan de hoog gechloreerde, en bepaalde congeneren worden in bijvoorbeeld varkens en koeien relatief goed afgebroken. Bij kippen leidt een verhoogde blootstelling tot effecten op het uitkomen van de eieren en tot 'chicken edema disease'. Beide effecten leidt tot de ontdekking van het dioxine-incident in 1999 in België. Bij andere landbouwhuisdieren zijn effecten minder duidelijk, het onderzoek naar effecten in andere landbouwhuisdierendieren is echter zeer beperkt. Bekend is dat de hoger gechloreerde congeneren zich ophopen in de levers van de dieren, wat met name bij schapen een probleem blijkt te zijn. Dioxines en PCB's worden door het dier uitgescheiden in melk en eieren. Bij langdurige blootstelling van het dier neemt die relatieve overdracht toe tot er een soort steady state wordt bereikt. In die situatie kan circa $40 \%$ van de ingenomen dosis worden uitgescheiden naar melk of eieren. Voor koeien betekent dit dat voer met een gehalte rond de norm kan leiden tot gehalten in melk rond de productnorm (2,5 pg/g vet, Verordening (EG) $\mathrm{nr}$. 1881/2006). Bij kippen zal in dat geval de productnorm voor eieren fors worden overschreden, en daarom hanteert de diervoedersector voor kippenvoer een veel lagere norm. Wanneer de blootstelling van melkkoeien of leghennen wordt beëindigd, zal het gehalte in melk of eieren in eerste instantie snel dalen tot ongeveer $50 \%$ van het oorspronkelijke hoge gehalte. Daarna treedt een veel langzamere fase in 
waarbij het lichaamsvet van de dieren als bron voor uitscheiding gaat werken. De halfwaardetijd ligt dan al snel rond een maand. Inmiddels zijn er modellen ontwikkeld voor melkkoe, leghen en varkens om dit verloop te voorspellen (Hoogenboom et al., 2007; Van Eijkeren et al., 2006). Bij groeiende dieren zoals varkens, vleeskuikens en jonge schapen moet naast actieve excretie ook rekening worden gehouden met de verdunning van de gehalten door de groei van de dieren. Voor dioxines in citruspulp werd een transferfactor van maximaal 0,58 vastgesteld voor de transfer van TCDD van pulp naar melk (Malisch and Kotz, 2014).Ook in vis kunnen dioxines en PCB's zich ophopen. Wanneer een deel van het visvoer vervangen wordt door plantaardige ingrediënten (zoals soja) gaan de concentraties dioxines en PCB's in vis omlaag (Bell et al., 2012; Berntssen et al., 2011a). Een overdrachtsstudie in zalm laat zien dat DL-PCB's beter worden overgedragen dan dioxines met overdrachtsfactoren (voereetbare delen) van respectievelijk 0,79 en 0,52. Overdracht van voer naar vis is hierbij een factor 6,5 hoger dan voor landbouwhuisdieren (Berntssen et al., 2011a).

\subsubsection{Regulering}

Begin jaren negentig heeft Nederland naar aanleiding van problemen rond vuilverbranders maatregelen getroffen om gehalten in melk te verlagen. Daarvoor werd onder meer een productnorm voor melk gesteld. Na het Belgische incident in 1999 heeft de EU besloten om maatregelen te treffen om de blootstelling aan dioxines verder te verlagen. Dit resulteerde in een pakket van maatregelen zoals GMP+ voor productie van diervoeders en ook tot de invoering van normen voor levensmiddelen en diervoeders (respectievelijk Verordening (EG) nr. 1881/2006 en Richtlijn 2002/32/EG). Die normen werden gesteld op basis van gehalten gerapporteerd door lidstaten volgens het principe "As Low As Reasonably Achievable (ALARA)"; dus streng genoeg om uiteindelijk te resulteren in een verlaging van de gehalten, maar niet zodanig dat teveel producten zouden moeten worden afgekeurd. In eerste instantie (2001) was dat alleen mogelijk voor dioxines, maar eind 2006 werden naast normen voor dioxines ook normen voor de som van dioxines en dioxineachtige PCB's ingevoerd. Het gevolg is een grote variatie in de normen voor de verschillende levensmiddelen en diervoedergrondstoffen. Het gehanteerde principe betekent ook dat er geen afstemming is tussen gehalten in diervoeders en dierlijke producten (JECFA Joint FAO/WHO Expert Committee on Food Additives., 1992; SCF., 2001). Bijvoorbeeld wanneer de diervoedernorm voor diervoeder voor leghennen overschreden wordt, dan kunnen de concentraties in eieren ca. $3 x$ boven de norm zijn. Diervoerderbedrijven houden hier wel rekening mee door een lagere actielimiet te hanteren.

Om het proces van verlaging van gehalten te versnellen werden ook actiedrempels ingevoerd voor zowel dioxines als voor dl-PCB's. Deze limieten zijn lager dan de maximumgehalten en bij overschrijding van de actielimiet moet onderzoek gestart worden naar de bron van de besmetting. De bedoeling was om na zo'n 5 jaar de normen verder te verlagen maar dat bleek niet mogelijk. Wel werden in 2012 de normen aangepast om de WHO-TEF factoren van 2005 in te voeren (Van den Berg et al., 2006). Doordat de TEF-factoren veranderden, werd - ondanks dat de concentraties van de individuele congeneren gelijk bleef - het TEQ-gehalte 15\% lager. Zoals vermeld werden in veel landen al langer indicator-PCB's gemeten en waren hier in sommige landen ook normen voor. Mede om die reden heeft de EU in 2012 geharmoniseerde normen ingevoerd voor levensmiddelen en diervoeders. Naast wetgeving voor toegestane gehalten zijn er regels vastgesteld waaraan de monstername en analyses moeten voldoen. Sinds kort gelden deze regels niet alleen voor officiële controles maar ook voor private partijen. Dit is feitelijk een uitbreiding van de wetgeving die in het leven werd geroepen voor diervoedervetten na het eerder genoemde dioxine-incident in Duitsland in 2010.

\subsubsection{Conclusie}

Er zijn voor dioxines overschrijdingen gevonden in verwerkte producten (zoals vismeel, oliën en vetten, en bijproducten) en additieven (zoals binders en antiklontermiddelen). Overdracht van dioxinen in het dier naar dierlijke producten, zoals melk en eieren, is mogelijk en heeft geleid tot incidenten in het verleden. Mede vanwege de hoge toxiciteit (dioxinen zijn door IARC gekwalificeerd als humaan carcinogeen; klasse I) komen dioxines daarom op de short-list voor diervoeders.

\subsubsection{Gebromeerde vlamvertragers}

\subsubsection{Algemeen}

Broomhoudende vlamvertragers (BFR's) zijn stoffen die zijn toegepast in diverse producten om te voorkomen dat het materiaal ontbrandt of om een brand te vertragen. BFR's zijn toegepast in vele, 
diverse industriële en consumentenproducten. Gedurende de productie en toepassing, bij gebruik van de producten en in de afvalfase kunnen de BFR's vrijkomen en in het milieu terecht komen. Een aantal BFR's heeft eigenschappen die vergelijkbaar zijn met die van andere persistente organische

verontreinigingen zoals dioxines en PCB's. BFR's zijn moeilijk afbreekbaar, accumuleren in organismen en zijn toxisch. Om die reden staan ze onder de aandacht van internationale overheden. EFSA heeft een reeks opinies uitgebracht over BFR's (EFSA, 2010, 2011a, 2011b, 2011c, 2012a, 2012b). Relatief bekende voorbeelden van BFR's zijn polybroom difenylethers (PBDE's) en hexabromocyclododecanen (HBCDD's). Theoretisch zijn er 209 mogelijke congeneren voor de PBDE's. In werkelijkheid is er een klein aantal dat veel voorkomt en teruggevonden wordt in het milieu. Voor HBCDD zijn er 16 mogelijkheden, zogenaamde stereo-isomeren. In de praktijk bestaat een technisch mengsel, voornamelijk uit drie stereo-isomeren, die de aanduiding $a, \beta$ en $\gamma$-HBCDD hebben, waarbij $Y$-HBCDD in de grootste hoeveelheid aanwezig is in het technisch mengsel (EFSA, 2011a).

Er zijn geen Europese maximumlimieten voor BFR's in diervoeder. Binnen GMP+ zijn BFR's evenmin opgenomen in de lijst van specific feed safety limits. Binnen het Nationaal Plan diervoeders wordt niet gemonitord op BFR's. Hierdoor zijn weinig Nederlandse data beschikbaar.

\subsubsection{Aanwezigheid vlamvertragers in sub-ketens}

In RASFF zijn geen meldingen gevonden over vlamvertragers in diervoeder tussen 2005 en 2015.

a. Primaire plantaardige productie

Sommige planten zijn in staat om PBDE's op te nemen uit de (vervuilde) bodem (Vrkoslavová et al., 2010). Echter, de bioconcentratiefactoren zijn laag $(0,01-0,1)$ wat betekent dat de opname relatief laag is ten opzichte van het gehalte in de bodem. Behalve voor sterk gecontamineerde locaties is het niet de verwachting dat hoge gehalten in planten aangetroffen worden door opname uit de bodem.

b. Import en verwerking plantaardige producten niet voedergewassen, $1^{\mathrm{e}}$ fase Informatie over een mogelijk risico op besmetting met BFR's bij import (zowel EU als uit derde landen) en verwerking van plantaardige producten is niet gevonden. Het is mogelijk dat besmetting ontstaat via aanraking met BFR-houdende materialen tijdens opslag of vervoer. Het is niet aannemelijk dat BFR's opgeslagen of vervoerde plantaardige producten contamineren, hoewel het niet uitgesloten kan worden.

c. Verwerking plantaardige producten, $2^{\mathrm{e}}$ fase

$\mathrm{Er}$ is geen informatie gevonden dat bij verwerking van plantaardige producten een risico bestaat voor besmetting met BFR's. Het is niet aannemelijk dat BFR's voederproducten contamineren bij de verwerking, hoewel het niet uitgesloten kan worden.

d. Verwerking plantaardige reststromen (voormalig levensmiddelen)

Er is geen informatie gevonden over mogelijke besmetting met BFR's bij de verwerking van plantaardige reststromen. Het is niet aannemelijk dat BFR's voederproducten contamineren, maar het kan niet worden uitgesloten.

e. Verwerking dierlijke producten, $1^{\mathrm{e}}$ en $2^{\mathrm{e}}$ fase

BFR's zijn vetoplosbaar (lipofiel) en komen met name voor in dierlijke producten afkomstig van aquatische organismen. Volgens Ortiz et al. (2011) kunnen PBDE's en HBCDD's aanwezig zijn in visolie (1-27 ng/g) die gebruikt wordt in diervoeder (Ortiz et al., 2011). In terrestrische dieren en producten daarvan zoals melkproducten, vetten en eiwitten komen ook BFR's voor, maar in lagere gehalten (Fernandes et al., 2016).

f. Verwerking bijproducten tot voedermiddelen BFR's zijn vetoplosbaar en zullen bij verwerking van bijproducten tot voedermiddelen voornamelijk voorkomen in de vette fractie van het voedermiddel.

\section{g. Chemische productie additieven}

Traag et al. (2009) publiceerden over een casus waarbij cholinechloride besmet was met een BFR, te weten FR-1808 (octabromotrimethylphenyllindaan). Ook werden in enkele monsters cholinechloride 
tribroomfenolen aangetroffen (Traag et al., 2009). Er heeft geen vervolgonderzoek plaatsgevonden, waardoor het niet bekend is of zo'n besmetting vaker voorkomt.

h. Productie mengvoeder

$\mathrm{Er}$ is geen reden om aan te nemen dat de productie op zichzelf bijdraagt aan de besmetting met BFR's. Wel kunnen ingrediënten gecontamineerd zijn, wat leidt tot gecontamineerd diervoeder.

\subsubsection{Overdracht naar dierlijke producten}

In de melk en levers van lacterende koeien zijn PBDE's aangetroffen afkomstig vanuit het diervoeder (Kierkegaard et al., 2007; Kierkegaard et al., 2009). De overdracht naar melk bedroeg 15-35\% voor BDE-47 en BDE-99. BDE-47, BDE-99, BDE-100, BDE-153 EN BDE-154 dragen sterker over dan BDE28, BDE-49 EN BDE-66 (Kierkegaard et al., 2007; Kierkegaard et al., 2009). BFR's kunnen in kweekvis accumuleren vanuit het diervoeder (van Leeuwen et al., 2009). Isosaari et al. (2005) onderzochten de accumulatie van PBDE's in zalm, en concludeerden dat ongeveer $95 \%$ van de PBDE's uit het voer teruggevonden werden in de gehele zalm, en $42-59 \%$ in de filet. Blanco et al. (2011) vonden een opname van $30 \%$ in tarbot filets vanuit het voer. In een studie van Berntssen et al. (2011b) vond men een opname van $31 \%$ a-HBCDD vanuit het voer in de filet (steady state nog niet bereikt).

\subsubsection{Regulering}

Er zijn geen maximum limieten opgenomen in EU-wetgeving voor BFR's in diervoeder.

\subsubsection{Conclusie}

Er zijn geen wettelijke limieten voor vlamvertragers in diervoeder en daardoor zijn ze ook niet opgenomen in nationale monitoring. $\mathrm{Er}$ is dus weinig bekend over het voorkomen van vlamvertragers in diervoeder. Overdracht naar dierlijke producten is mogelijk. Om een inschatting te maken over de prioriteit van deze groep stoffen zijn meer gegevens nodig.

\subsubsection{Perfluorverbindingen}

\subsubsection{Algemeen}

Per- en polyfluoralkylverbindingen (PFAS's) betreffen een groep van stoffen van (volledig) gefluoreerde verbindingen. Er zijn honderden verbindingen bekend, met uiteenlopende chemische structuren (ketenlengte, functionele groepen etc.) (Buck et al., 2011). De twee bekendste PFAS's zijn perfluoroktaansulfonzuur (PFOS) en perfluoroktaanzuur (PFOA). Andere redelijk bekende PFAS's hebben een vergelijkbare functionele groep maar een andere ketenlengte. Het betreft perfluorbutaanzuur (PFBA), perfluorpentaanzuur (PFPA), perfluorhexaanzuur (PFHXA), perfluorheptaanzuur (PFHpA), perfluornonaanzuur (PFNA), perfluordecaanzuur (PFDA), perfluorundecaanzuur (PFUnA), perfluordodecaanzuur (PFDoA), perfluortridecane (PFTrA), perfluortetradecane (PFTrA), perfluorbutaansulfonaat (PFBS), perfluorhexaansulfonaat (PFHXS) en perfluordecaansulfonaat (PFDS). PFAS's zijn uitermate stabiel: ze zijn bestand tegen hoge temperaturen en chemisch nagenoeg inert. PFAS's zijn water-, vet-, en vuilafstotend en oppervlaktespanning-verlagend. Hierdoor zijn deze stoffen breed toegepast, ze zijn gebruikt bij oppervlaktebehandelingen van bijvoorbeeld tapijten, textiel en leer, maar ook als surfactant in blusschuim en in de mijnbouw en olie-industrie. PFOS is een Persitent Organic Pollutant (POP), vanwege zijn persistente, bioaccumulatieve en toxische eigenschappen ${ }^{1}$. PFOA is toxisch en persistent, maar is niet aangemerkt als POP, omdat het beperkt bioaccumulatief is. PFAS's komen in ons voedsel voor (Noorlander CW., 2011). PFOS en PFOA hopen niet op in vetten, in tegenstelling tot dioxines en PCB's, maar binden aan eiwitten in het bloed en de lever.

\subsubsection{Aanwezigheid perfluorverbindingen in de sub-ketens}

a. Primaire plantaardige productie

PFAS's kunnen opgenomen worden in plantaardige gewassen. Dit is aangetoond voor o.a. maïs. Het toedienen van PFAS's in het grond leidde tot opname in de plant. PFBA, PFPA, PFHXA, PFHpA, PFOA, PFBS, PFHxS en PFOS werden opgenomen in de plant, waarbij opname van de korte ketens het

\footnotetext{
${ }^{1}$ http://chm.pops.int/TheConvention/ThePOPs/ListingofPOPs
} 
grootst was (Krippner et al., 2015). Naast experimenteel bewijs zijn er enkele casussen van besmetting gepubliceerd. Kowalczyk et al. (2013) beschreef een casus in Noordrijn-Westfalen, waar gras en hooi gecontamineerd was met diverse PFAS's (12-2845 ng/g droog gewicht), afkomstig van met PFAS's gecontamineerde meststof. Zafeiraki et al. (2016b) heeft, als onderdeel van een overdrachtsstudie (zie onder), PFOS gemeten in gras uit de uiterwaarden van de IJssel. De gehalten lagen rond de $0,5 \mathrm{ng} / \mathrm{g}$. PFOS was waarschijnlijk opgenomen door het gras uit gecontamineerd rivierslib en/of rivierwater.

b. Invoer, import en verwerking plantaardige producten niet voedergewassen, $1^{\mathrm{e}}$ fase PFAS's kunnen opgenomen worden in plantaardige producten. Hoewel er weinig informatie bekend is over het voorkomen van PFAS's in plantaardige producten wordt aangenomen dat ze slechts in beperkte mate aanwezig zijn (behalve in hot-spot gevallen).

c. Verwerking plantaardige producten, $2^{\mathrm{e}}$ fase

PFAS's kunnen opgenomen worden in plantaardige producten. Hoewel er weinig informatie bekend is over het voorkomen van PFAS's in plantaardige producten wordt aangenomen dat ze slechts in beperkte mate aanwezig zijn (behalve in hot-spot gevallen).

d. Verwerking plantaardige reststromen (voormalig levensmiddelen)

PFAS's kunnen voorkomen in plantaardige voedingsmiddelen, maar op een laag niveau $(<0,2-18 \mathrm{pg} / \mathrm{g}$ product) (Noorlander CW., 2011). Het is niet uit te sluiten dat plantaardige reststromen bijdragen aan de besmetting in de diervoederketen, maar het is niet bekend in welke mate. Indien retourstromen verpakt waren in met PFAS's behandelde vet- en vochtafstotende verpakkingen, dan is het aannemelijk dat deze bijdragen aan de besmetting van diervoeders. Ook hiervan is niet bekend in welke mate dit gebeurt.

e. Verwerking dierlijke producten, $1^{\mathrm{e}}$ en $2^{\mathrm{e}}$ fase

PFAS's hopen zich op in alle delen van het lichaam, met name de stoffen met langere ketens (PFOS, PFDA t/m PFTA). Gehalten kunnen hoog zijn in levers en nieren zoals hieronder aangegeven (paragraaf overdracht naar dieren), maar ook in andere delen van het lichaam. Er zijn veel studies waarin het voorkomen van PFAS's in (wildvang) vis wordt aangetoond. Er zijn echter maar weinig studies naar PFAS's in vismeel. Suominen et al. (2011) onderzochten een klein aantal vismeelmonsters en vonden daarin met name PFOS, PFDA, PFUnA en PFDoA tot een niveau van $1,5-20 \mathrm{ng} / \mathrm{g}$ (12\% vocht). Vanwege de grote variatie van gehalten benadrukten ze de noodzaak voor verder onderzoek. Er is geen studie gevonden over de efficiency van vismeel processing voor het verwijderen van PFAS's. Dit betekent dat bij- en restproducten die gebruikt worden voor diervoeder ook PFAS's kunnen bevatten.

f. Verwerking bijproducten tot voedermiddelen

Hier is niets over bekend in relatie tot besmetting met PFAS's.

g. Chemische productie additieven

Hier is niets over bekend in relatie tot besmetting met PFAS's.

h. Productie mengvoeder

Ingrediënten zoals vismeel kunnen gecontamineerd zijn, zoals hierboven beschreven, wat leidt tot besmetting van het mengvoeder. Het is niet aannemelijk dat het productieproces zelf bijdraagt aan de besmetting met PFAS's.

\subsubsection{Overdracht naar dierlijke producten}

PFAS's komen voor in kweekvis (Shi et al., 2012; van Leeuwen et al., 2009). Ze worden overgedragen vanuit het diervoeder, zoals aangetoond door Goeritz et al. (2013) in een overdrachtsstudie in forel. De biomagnificatiefactoren (BMF's; concentratie in vis in steady state gedeeld door de concentratie in het voer) bedroeg 0,42 voor PFOS, 0,23 voor PFNA, 0,18 voor PFHxS, 0,04 voor PFOA en 0,02 voor PFBS. Hieruit blijkt dat de langere ketens efficiënter worden opgenomen in de vis dan de kortere ketens. Ophoping gebeurt met name in de organen (o.a. lever) en in mindere mate in de filet. Kortere ketens worden na opname sneller uitgescheiden. Zafeiraki et al. (2016b) hebben de opname van 
PFAS's in schapenlevers vanuit natuurlijk gecontamineerd gras afkomstig van de IJssel uiterwaarden bestudeerd. Na 112 dagen was het gehalte in de lever opgelopen tot 10,9 ng/g, wat overeenkomt met circa $12 \%$ van de hoeveelheid die via voeding was ingenomen. In een survey bleek dat PFOS met name in de levers van paarden en schapen gevonden wordt, mogelijk omdat deze dieren veel buiten grazen.

De overdracht van PFAS's vanuit voeder naar runderen is onderzocht door Kowalczyk et al. (2013). PFOS en PFHxS hoopten voornamelijk op in lever en nieren van de dieren (hoogste concentraties), maar een substantieel deel werd ook opgeslagen in de totale spiermassa van de dieren. Ongeveer $14 \%$ van de opgenomen PFOS werd via de melk uitgescheiden. De kortere ketens hoopten niet op, maar werden via de urine uitgescheiden. Van Asselt et al. (2013) hebben op basis van deze dataset een PBPK-model ontwikkeld, waaruit een halfwaardetijd van 56 dagen werd afgeleid voor afname van PFOS-gehalten in melk. Zafeiraki et al. (2016a) onderzochten PFAS's gehalten in commerciële eieren en in eieren van hobbyboeren. Met name in de laatste categorie zijn PFAS's aangetroffen, naar verwachting als gevolg van fourageergedrag (het oppikken van gecontamineerde grond samen met het voeder).

Samenvattend speelt besmetting van diervoeder met name een rol in gevallen waarin dieren buiten voederen of in geval dieren gevoederd worden met gewas dat van gecontamineerde plaatsen afkomstig is (zoals maïs en gras). Ook vismeel in het mengvoeder kan een bijdrage leveren aan de blootstelling.

\subsubsection{Regulering}

Er zijn geen maximum gehalten vastgesteld voor PFAS's in veevoeder (ingrediënten). Er is op geen andere wijze regulering van PFAS's besmetting in diervoeders. Er zijn dan ook weinig nationale monitoringsgegevens voorhanden.

\subsubsection{Conclusie}

Er zijn geen wettelijke limieten voor perfluorverbindingen in diervoeder en daardoor zijn ze ook niet opgenomen in nationale monitoring. Er is dus weinig bekend over het voorkomen van perfluorverbindingen in diervoeder. Overdracht naar dierlijke producten is mogelijk, m.n. naar lever en nieren maar ook naar vlees, melk en eieren en speelt vooral een rol bij lokale besmettingen van de omgeving. Om een inschatting te maken over de prioriteit van deze groep stoffen zijn meer gegevens nodig.

\subsubsection{Zware metalen}

\subsubsection{Algemeen}

Diervoeder kan verschillende potentieel zware metalen bevatten, zoals lood, cadmium, kwik en arseen. Deze zware metalen kunnen in het diervoeder terechtkomen via gewassen die geteeld zijn op verontreinigde bodems, door mineralen die toegevoegd worden aan het diervoeder (Nicholson et al., 1999; Zhang et al., 2012) en via voedermiddelen van marine oorsprong (o.a. vismeel, zeewier).

Zware metalen komen van nature voor in de bodem, maar kunnen ook in de bodem terechtkomen via gebruik van kunst- en dierlijke mest (CLO, 2013). Vanuit de bodem kunnen zware metalen worden opgenomen in gewassen. Via diervoeder kunnen die metalen vervolgens terechtkomen in dierlijke producten en vervolgens in de mens. Methylkwik is toxischer dan anorganisch kwik en Anorganisch arseen is toxischer dan organisch arseen.

Koper en zink zijn essentiële elementen voor dieren, en worden als additief toegevoegd aan diervoeder. Zij hebben geen relevantie voor humane gezondheid maar wel voor het milieu. Nikkel kan via het milieu terechtkomen in diervoederingrediënten of door toevoeging van gehydrogeneerde plantaardige oliën waar nikkel als katalysator kan worden gebruikt voor het harden van vetten. Dit heeft waarschijnlijk geen effect op de diergezondheid, maar kan wel via consumptie van dierlijke producten (bijv. melk) een effect hebben op de humane gezondheid. Dit geldt vooral voor kleuters, maar in geval van hoge consumptie ook voor oudere kinderen (EFSA, 2015). Naast chronische effecten, kan de consumptie van dierlijke producten die nikkel bevatten voor gevoelige personen ook leiden tot acute effecten, zoals huidreacties (Anke et al., 1995). 


\subsubsection{Aanwezigheid zware metalen in sub-ketens}

De mogelijke aanwezigheid van zware metalen in de diversie sub-ketens is onderzocht voor de gereguleerde zware metalen (cadmium, lood en kwik) en het toxische element arseen.

In de KAP-databank (2007-2013) varieert het percentage monsters (ingrediënten en eindproducten) met een cadmiumconcentratie boven de ML tussen de $0-16 \%$ afhankelijk van het onderzochte product. Het percentage monsters met een loodconcentratie boven de ML lag tussen de 0-10\% en voor kwik lag dit percentage tussen $0-3 \%$. Het percentage monsters in de Nederlandse monitoringsgegevens met een arseenconcentratie boven de ML varieert van 0 tot $>10 \%$ (voor monsters zeewier). De gegevens betroffen in het algemeen de totale hoeveelheid arseen (organisch en anorganisch) (Adamse et al., 2017). Recentere resultaten van het NP Diervoeder laten lage percentages overschrijdingen zien, tussen 0 en $2.3 \%$. Overschrijdingen werden gevonden voor lood in kleimineralen en voor arseen in algen/zeewier. De RASFF-databank bevat 173 meldingen voor zware metalen in de periode 2005- 2015, waarvan 46 voor arseen, 45 voor cadmium, 34 voor kwik, en 30 voor lood. Zware metalen werden voornamelijk aangetroffen in spoorelementen, visproducten en palmpitschilfers.

Adamse et al. (Adamse et al., 2017) heeft op basis van monitoringsresultaten opgeslagen in de KAPdatabank (Nationaal Plan diervoeder, SecureFeed) voor data van 2007-2013 een prioritering gemaakt voor monitoring op elk van cadmium, lood, kwik en arseen. Hierbij zijn diervoeders per element ingedeeld in de klassen laag, middel en hoge prioriteit voor monitoring (Tabel 8). Diervoeders of diervoedergrondstoffen die ingedeeld zijn in de midden en hoge prioriteit klasse voor één of meerdere van deze elementen zijn in Tabel 8 weergegeven; diervoeders met lage prioriteit zijn achterwege gelaten. De indeling in de drie prioriteit klassen is - per diervoeder en element - gebaseerd op het aantal RASFF-meldingen (4e kolom in de tabel) - en op basis van analyse van de monitoringsgegevens - de gemiddelde concentratie ( $5^{e}$ kolom in de tabel), het percentage monsters boven de wettelijke limiet (6e kolom in de tabel) en de uitkomst van de trendanalyse (7e kolom in de tabel). Trendanalyses zijn uitgevoerd op de gemiddelde concentraties van de zware metalen in diervoeders tussen 2007 en 2013. Wanneer er een significant positieve trend werd gevonden, werd dit in de tabel met een + weergegeven, een significant negatieve trend met een -, en indien er geen significante trend waarneembaar was met een 0 . Een trend werd als significant aangegeven als de $\mathrm{R}$-square $\left(\mathrm{R}^{2}\right)$ van de trendlijn hoger was dan 0,30. Diervoeders krijgen een gemiddelde prioriteit (oranje kleur) als 1 van deze variabelen hoog is (meer dan 5 RASFF-meldingen, de gemiddelde concentratie is meer dan $20 \%$ van de $\mathrm{ML}$, het percentage overschrijdingen is meer dan $3 \%$ of er is een significante toename te zien in de afgelopen jaren). Diervoeders krijgen een hoge prioriteit als twee of meer van deze variabelen hoog zijn of als het percentage overschrijdingen meer dan $10 \%$ is.

Er is geen maximale limiet voor de aanwezigheid van nikkel in diervoeders, en er zijn weinig gegevens bekend over de aanwezigheid van nikkel in diervoeder. Een recente oproep van EFSA leverde monitoringsgegevens op in mengvoer, ruwvoer en gerelateerde producten en graan(producten) uit Slowakije. De gemiddelde concentratie nikkel in deze producten lag tussen de $139 \mu \mathrm{g} / \mathrm{kg}$ voor rogge en $3895 \mu \mathrm{g} / \mathrm{kg}$ voor geroosterde sojabonen (EFSA, 2015). 
Tabel 8 Hoge (rood) en middel (oranje) prioriteit in monitoring van zware metalen op basis van monitoringsgegevens van diervoeder en -ingrediënten tussen 2007 en 2013 (Adamse et al., 2017). Groepering producten op basis van EC limieten.

\begin{tabular}{|c|c|c|c|c|c|c|c|}
\hline Producten bedoeld voor diervoeder & $\begin{array}{l}\text { ML } \\
(\mathrm{mg} / \mathrm{kg})\end{array}$ & $\begin{array}{l}N \\
(2007- \\
2013)\end{array}$ & $\begin{array}{l}\text { RASFF } \\
(2007- \\
2013)\end{array}$ & $\begin{array}{l}\text { Gemiddelde } \\
\text { ( } \% \text { of ML) }\end{array}$ & $\begin{array}{l}\%> \\
M L\end{array}$ & $\begin{array}{l}\text { Trend } \\
\text { gemiddelde } \\
\left(R^{2}\right)\end{array}$ & Prioriteit ${ }^{1}$ \\
\hline
\end{tabular}

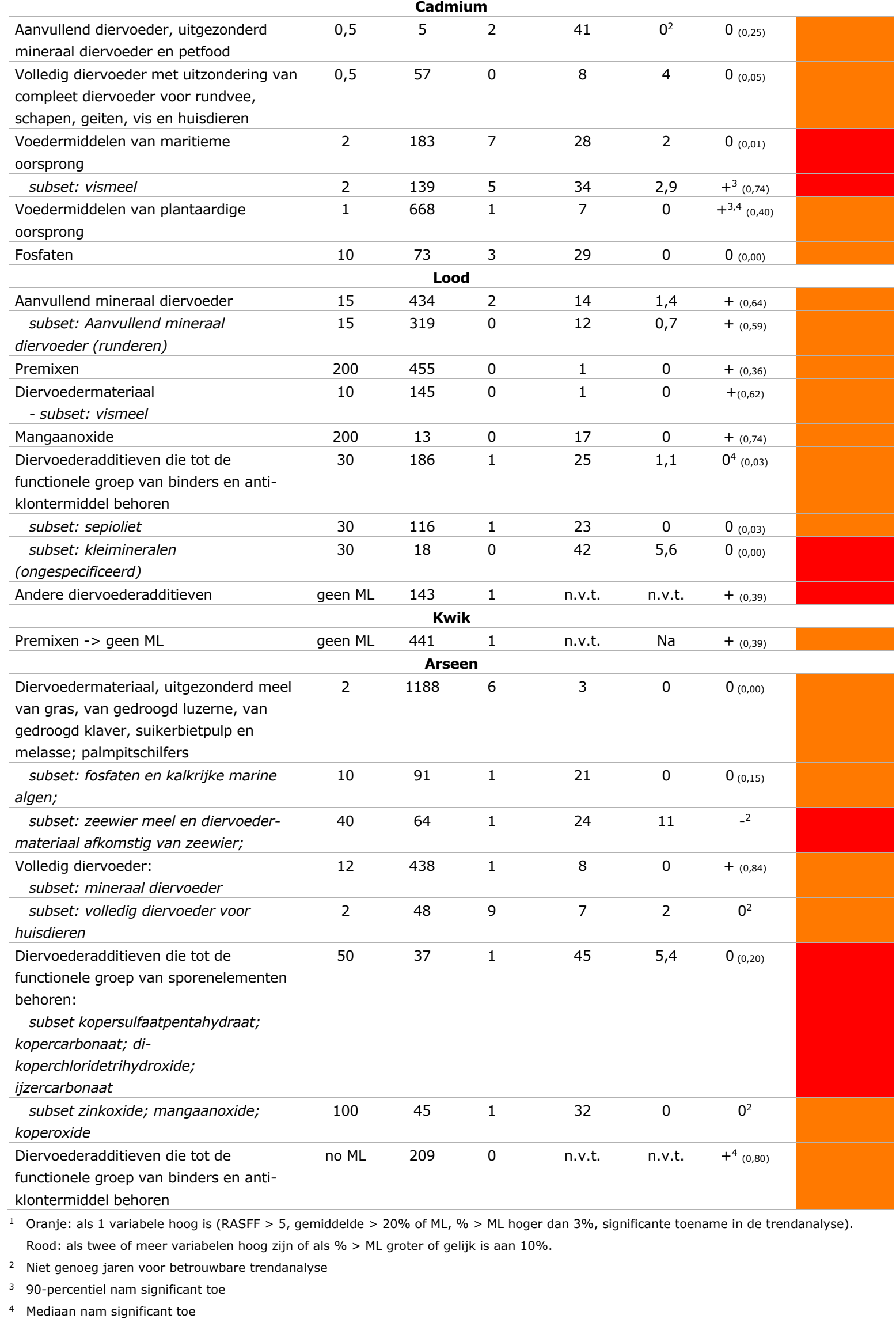


a. Primaire plantaardige productie

Cadmium, lood en arseen kunnen via de bodem en de lucht worden opgenomen in planten. Risicovolle groenten zijn bladgewassen zoals sla en boerenkool, en knol- en wortelgewassen. Voor diervoeder is suikerbiet het meest gevoelige gewas voor ophoping van zware metalen (Römkens et al., 2007). Analyse van de KAP-data laat zien dat voedermiddelen van plantaardige oorsprong een medium prioritering krijgen voor cadmium (Adamse et al., 2017).

b. Invoer, import en verwerking plantaardige producten niet voedergewassen, $1^{\mathrm{e}}$ fase Zoals eerder aangegeven kunnen zware metalen in het milieu (bodem, lucht of water) aanwezig zijn. Vervuiling met zware metalen is vooral een probleem in dichtbevolkte en sterk geïndustrialiseerde gebieden ( Li et al., 2014). Volgens RASFF zijn landen waar het vaakst zware metalen gevonden worden: West-Europese landen (België, Frankrijk, Spanje, Polen) en Aziatische landen (vooral Thailand). Wanneer plantaardige producten uit dergelijke landen geïmporteerd worden is de kans op aanwezigheid van zware metalen in deze producten dan ook groter.

Door verwerking van plantaardige producten en voedergewassen kan het gehalte aan zware metalen verlaagd dan wel verhoogd worden. Zo zijn concentraties in de schil van de aardappel hoger dan in de aardappel zelf (Davies and Crews, 1983). Eindconcentraties in mengvoeders zijn dus afhankelijk van het gedeelte van de plant dat gebruikt wordt voor de bereiding van diervoeder.

c. Verwerking plantaardige producten, $2^{\mathrm{e}}$ fase

De kans op aanwezigheid van zware metalen in producten van deze subcategorie wordt laag ingeschat. Zoals eerder aangegeven worden zware metalen voornamelijk in bladgroenten en knol en wortelgewassen gevonden en in veel lagere concentraties in granen en zaden. Verwerking van deze grondstoffen tot bakkerijproducten of oliën zal dan ook niet tot hoge concentraties zware metalen leiden. Suikerbieten kunnen wel zware metalen bevatten en de bijproducten bij de verwerking van deze grondstoffen (bietenpulp) dus ook.

d. Verwerking plantaardige reststromen (voormalig levensmiddelen) Retourstromen van de brood-en banketindustrie of de alcoholindustrie bevatten naar verwachting weinig tot geen zware metalen.

e. Verwerking dierlijke producten, $1^{\mathrm{e}}$ en $2^{\mathrm{e}}$ fase

Voedermiddelen van maritieme oorsprong kunnen zware metalen bevatten. Analyses van de KAP-data laat zien dat deze categorie als hoog risico wordt geprioriteerd voor de aanwezigheid van cadmium en arseen. Arseen werd vooral gevonden in zeewier en algen (Adamse et al., 2017). Analyse van de RASFF-data in de periode 2005 - 2016 laat zien dat het merendeel van de 34 meldingen voor kwik visproducten betrof. In visproducten, waaronder vismeel, is kwik voornamelijk aanwezig in de vorm van het toxische methylkwik.

f. Verwerking bijproducten tot voedermiddelen

Wanneer visproducten verder verwerkt worden, kunnen bijproducten hiervan zware metalen bevatten. Ook organen, zoals lever en nieren, kunnen verhoogde concentraties zware metalen bevatten, omdat metalen hierin ophopen. Orgaanvlees mag echter niet verwerkt worden in diervoeder voor landdieren, wel in petfood. (Verordening (EG) 999/2001). Zware metalen zijn veelal vet oplosbaar en kunnen daarom aanwezig zijn in dierlijke vetten.

\section{g. Chemische productie additieven}

Sommige additieven van minerale oorsprong bevatten hoge gehalten aan zware metalen en worden gezien als diervoederingrediënten met hoge prioriteit voor monitoring (Tabel 8). Kleimineralen zijn de belangrijkste bron voor lood, en sporenelementen zoals kopersulfaat, kopercarbonaat en ijzercarbonaat als belangrijkste bronnen voor arseen. Sinds 2012 mogen mycotoxinebinders gebruikt worden als diervoederadditief. Deze binders bevatten vaak kleicomponenten. Gebruik van deze binders kan leiden tot verhoogde loodconcentraties in diervoeder en om deze reden zouden mycotoxinebinders opgenomen moeten worden in de monitoring. Tot op heden is er echter geen ML voor deze binders. Soms worden ze (verkeerd) geclassificeerd als aanvullend diervoeder ( $M L=$ $10 \mathrm{mg} / \mathrm{kg}$ ) of als minerale $\operatorname{mix}(\mathrm{ML}=15 \mathrm{mg} / \mathrm{kg}$ ) (Adamse et al., 2017). 


\section{h. Productie mengvoeder}

Naar verwachting ontstaan er geen extra gevaren door het mengen van ingrediënten, verpakken en bewaren van mengvoeder. Aanvullend mengvoeder (uitgezonderd minerale mengsels en petfood) is ingedeeld in de medium prioriteit groep voor cadmium omdat in de periode 2007-2013 de gemiddelde cadmium concentratie meer dan $20 \%$ van de $M L$ was. Het is niet bekend welke ingrediënten voor deze verhoogde concentraties zorgden. Voor lood viel aanvullend diervoeder met mineralen in de medium prioriteit groep en werden diverse ML-overschrijdingen gevonden (Adamse et al., 2017). Dit komt waarschijnlijk omdat lood aanwezig kan zijn in kleimineralen.

\subsubsection{Overdracht naar dierlijke producten}

Wanneer dieren zware metalen binnenkrijgen, hopen deze zich vooral op in de lever en de nieren (Crout et al., 2004; Kan and Meijer, 2007; MacLachlan, 2011). Zware metalen waarvan bekend is dat ze overgedragen kunnen worden naar dierlijke producten en vervolgens naar de mens zijn cadmium, lood, kwik en arseen (Kan and Meijer, 2007). Nikkel kan via diervoeder worden overgedragen naar mens, o.a. via melk.

Een recente studie van het RIVM laat zien dat de gemiddelde cadmiuminname in Nederland varieert van $0,20 \mu \mathrm{g} / \mathrm{kg}$ lichaamsgewicht voor volwassenen tot $0,57 \mu \mathrm{g} / \mathrm{kg}$ lichaamsgewicht voor 2 -jarigen. Hoewel de hoogste concentraties cadmium in orgaanvlees en bepaalde typen vis gevonden werden, dragen deze producten weinig bij aan de totale inname, doordat ze weinig geconsumeerd worden (Sprong and Boon, 2015). EFSA (2012) kwam tot dezelfde conclusie: de hoogste concentraties cadmium werden gevonden in maritieme producten (algen, zeewier, weekdieren, schaaldieren), producten die cacao bevatten, orgaanvlees, paddenstoelen en oliezaden, maar de producten die het meest bijdroegen aan de cadmiuminname waren graan(producten), groenten(producten) en zetmeelhoudende wortels en knollen. Ook voor anorganisch arseen geldt dat - gebaseerd op innameberekeningen - granen (uitgezonderd rijst) de belangrijkste voedselgroep vormen voor inname van de mens, gevolgd door een aantal andere producten (rijst, zuivel en drinkwater) (EFSA 2014a).

\subsubsection{Regulering}

De belangrijkste zware metalen die een effect kunnen hebben op de humane gezondheid zijn: lood, cadmium, kwik en arseen. Richtlijn 2002/32/EG geeft de maximale gehalten aan voor elk van deze vier zware metalen in diervoeders met een vochtgehalte van $12 \%$. Voor anorganisch arseen is er een maximumgehalte opgenomen voor palmpitschilfers, vis(producten) en zeewier. Voor dierlijke producten zijn er alleen wettelijke limieten voor cadmium, lood en kwik (Verordening (EG) 1881/2006). Voor koper en zink in diervoeder zijn er wettelijke limieten en richtlijnen (Verordening (EG) nr. 1334/2003 en Richtlijn 86/300/EG). Voor nikkel is er geen ML in diervoeder, wel zijn er GMP+-limieten vastgesteld. Voor het gebruik van mest en compost op het land zijn maximale waarden vastgesteld voor zware metalen in het Uitvoeringsbesluit meststoffenwet. Dit is bedoeld om verontreiniging van de bodem en vervolgens opname door gewassen te voorkomen.

\subsubsection{Conclusie}

Er zijn overschrijdingen van de ML's gevonden voor de gereguleerde zware metalen (lood, cadmium, kwik en arseen). Overdracht naar dierlijke producten is mogelijk (m.n. naar lever en nier). Deze vier zware metalen worden daarom opgenomen op de short-list voor diervoeder. Koper en zink vormen geen gevaar voor de humane gezondheid, maar hebben vooral een effect op het milieu. Voor nikkel is meer onderzoek nodig.

\subsubsection{Mycotoxines}

\subsubsection{Algemeen}

Mycotoxines vormen een grote, diverse groep van toxische, secundaire metabolieten van schimmels die onder bepaalde omstandigheden -worden geproduceerd tijdens en na de schimmelinfectie van het gewas op het veld of tijdens opslag. Het weer, met name vocht en temperatuur tijdens bepaalde fases van de gewasgroei, heeft een belangrijke invloed op de mate van schimmelinfectie en toxineproductie. Daarnaast hebben agronomische factoren zoals variëteit van het gewas en de zaai- en oogstdatum en/of opslag condities invloed op de schimmelinfectie en/of mycotoxineproductie door de schimmels. In de literatuur zijn meer dan 300 verschillende mycotoxines beschreven (CAST, 2003). Bepaalde schimmelsoorten kunnen meer dan één mycotoxine produceren, en hetzelfde mycotoxine kan door 
verschillende schimmels worden gevormd. In de laatste decennia komt er, mede door de ontwikkelingen in analytische methoden, steeds meer aandacht voor gemodificeerde vormen van mycotoxines. Hierbij wordt door de schimmel of de plant het mycotoxine gekoppeld aan een suiker of sulfaatgroep (Rychlik et al., 2014). In de darm van het dier wordt het mycotoxine weer (terug)gevormd als gevolg van de-conjugatie en draagt het bij aan de blootstelling van het dier. Mycotoxinen die in de bloedbaan van het dier zijn opgenomen kunnen als dusdanig worden uitgescheiden in urine en melk, zoals zearalenon, maar het dier kan ook metabolieten vormen en uitscheiden (EFSA, 2016a). Voorbeeld hiervan is aflatoxine $M_{1}$ in koemelk (Womack et al., 2015). Mycotoxines komen wereldwijd voor in een grote diversiteit aan diervoeder en voedselgewassen. In diervoeder kunnen veel verschillende mycotoxines (tegelijkertijd) voorkomen. Dit heeft te maken met de variëteit aan diervoedergrondstoffen, de veelheid aan herkomstlanden (met verschillende klimatologische omstandigheden), en de aanwezigheid van verschillende soorten schimmels tegelijk in bepaalde regio's. Mycotoxines die het meest van belang zijn in diervoeder dat in Nederland wordt geproduceerd en/of op de markt wordt gebracht, vanwege hun aanwezigheid en toxiciteit, zijn toxinen geproduceerd door Aspergillus, Claviceps, Fusarium en Penicillium schimmels, te weten aflatoxinen, ergot alkaloïden, trichothecenen, zearalenon en fumonisinen (Binder et al., 2007).

Aflatoxines worden geproduceerd door Aspergillus flavus en, in mindere mate, door Aspergillus parasiticus, en omvat de vier aflatoxines $B_{1}, B_{2}, G_{1}$ en $G_{2}$. Van deze aflatoxines is aflatoxine $B_{1}$ het meest toxisch en meest voorkomend. Aflatoxines kunnen met name voorkomen in producten die uit (sub)tropische landen worden geïmporteerd, zoals korrelmaïs, rijst, zonnebloemen en pinda's. De laatste twee decennia worden aflatoxines steeds vaker aangetroffen in granen die geteeld zijn in de zuidelijke landen van Europa, zoals in korrelmais in Italië in 2003 en 2008, en in korrelmais in de Balkan regio in 2013 (Camardo Leggieri et al., 2015; de Rijk et al., 2015; Mauro et al., 2015).

Ergot alkaloïden wordt gevormd door de schimmel Claviceps purpurea (EFSA, 2017a). De grootste concentratie van de mycotoxinen bevinden zich in de sclerotia die de schimmel vormt in de aren tijdens de veld periode van het gewas. Maar er worden nog steeds ergot alkaloïden aangetroffen in geschoond graan. In de EU wordt het vaakst rogge genoemd als besmet met ergot sclerotia en ergot alkaloïden.

Fusarium schimmels komen wereldwijd voor en infecteren voedergewassen tijdens de veldperiode, vooral in gematigde klimaatzones. In Noordwest Europa zijn Fusarium graminearum en Fusarium culmorum de meest voorkomende toxineproducerende Fusarium schimmels. Fusarium mycotoxinen komen voor in granen, met name in maïs, tarwe, gerst en haver. De gevormde toxinen zijn voornamelijk trichothecenen, zearalenon (ZEA) en fumonisinen. Relevante trichothecenen zijn deoxynivalenol (DON) en in mindere mate- nivalenol, diacetoxyscirpenol en T-2/HT-2 toxinen. DON kan in hoge concentraties voorkomen in maïs en tarwe, en - in het algemeen in wat minder hoge concentraties - in gerst en haver. Het voorkomen is echter sterk afhankelijk van klimatologische omstandigheden, en kan daarom sterk variëren tussen regio's en jaren. In maïs en tarwe komen DON en ZEA vaak gezamenlijk voor. De laatste jaren wordt ook steeds meer DON en ZEA aangetroffen in maïs ingevoerd uit bepaalde Europese landen, waaronder Frankrijk. Maïs uit Zuid Europese landen en landen met een (sub)tropisch klimaat kan besmet zijn met fumonisine (de Rijk et al., 2015; Scudamore and Patel, 2008).

$\mathrm{T}-2 / \mathrm{HT}-2$ toxinen worden in bepaalde jaren in hoge concentraties aangetroffen in haver en gerst die geproduceerd zijn in de Scandinavische landen en het VK.

Ochratoxine A (OTA) kan worden geproduceerd door Penicillium verrucosum en andere Aspergillus en Penicillium soorten. Dit toxine komt voor in voedselproducten zoals koffie, wijn en bier. In diervoedergrondstoffen van plantaardige oorsprong, zoals granen, rijst en bonen, zijn OTA concentraties gerapporteerd van 1-100 ng/g (Malir et al., 2016). Het wordt meest geassocieerd met "mouldy products" wat betekent dat het geoogste product onder te vochtige omstandigheden is opgeslagen en is beschimmeld.

Tijdens de teelt worden met name trichothecenen, zearalenon, fumonisinen, aflatoxines en ergotalkaloïden gevormd. Fumonisinen en aflatoxines worden gevormd door schimmels die in warme gebieden voorkomen. Granen geïmporteerd uit dergelijke landen kunnen dus deze mycotoxines bevatten. Bovendien geldt dat deze schimmelsoorten naar het noorden in Europa opschuiven door 
klimaatverandering (Paterson and Lima, 2011). Mycotoxines die na het inkuilen worden gevormd, zijn met afkomstig van Penicillium roqueforti, Penicillium paeum en Aspergillus fumigatus (Driehuis et al., 2008). In Nederland worden gras en snijmaïs vaak geteeld voor het maken van kuilvoer voor melkkoeien. Hierbij wordt maïs en gras gedroogd en ingekuild in plastic balen of in een afgedekte kuil bewaard. Vaak worden middelen toegevoegd voor een snelle verzuring. Mycotoxines in kuilvoer kunnen ontstaan door schimmelinfecties tijdens de teelt en/of tijdens de opslag door slecht kuilmanagement. Indien de kuil of balen niet goed luchtdicht zijn afgesloten of wanneer de voersnelheid te laag is na het openen van de kuil kunnen mycotoxines gevormd worden. Besmetting met mycotoxines tijdens de teelt van diervoeder kan beperkt worden door te werken volgens de principes van Good Agricultural Practices (GAP). Echter, schimmels en mycotoxines kunnen nooit helemaal geëlimineerd worden omdat de groei mede afhankelijk is van de lokale weersomstandigheden (van der Fels-Klerx and Booij, 2010). Infecties in grasgebieden zijn moeilijker te voorkomen en te beheersen. Bij goed drogen en juiste opslag van de oogst kan mycotoxine productie worden verminderd. De verwerking van granen kan de concentratie aan mycotoxines in het bijproduct dat voor diervoeder gebruikt wordt beïnvloeden.

Mycotoxines zijn vaak geconcentreerd in de buitenste laag van de tarwekorrels. Ze worden dan ook met name gevonden in bepaalde bijproducten van het graan, zoals de schillen, schroten en buitenlagen zoals de zemelen (Brera et al., 2013; Tittlemier et al., 2014). De zemelen die worden verwijderd tijdens het malen voor gebruik van tarwe in voedsel en andere bijproducten van verwerking van granen voor voedsel worden vaak verder verwerkt tot diervoeders. In deze bijproducten worden gehalten gevonden van mycotoxines van 150-340\% van het oorspronkelijke product (Cheli et al., 2013). In bijproducten van bio-ethanol, Dried Distillers Grain with Solubles (DDGS), vindt een circa 3-voudige concentratie plaats van de mycotoxinegehalten ten opzichte van het uitgangsmateriaal (Khatibi et al., 2014).

\subsubsection{Aanwezigheid mycotoxines in sub-ketens}

Ongeveer de helft van alle RASFF-meldingen voor diervoeder tussen 2005 en 2015 (740 meldingen) betreft aflatoxines. Dit mycotoxine werd gevonden in grondnoten (563 meldingen), maïs (88 meldingen), en overige producten zoals rijst, zonnebloem, sorghum etc. ( 89 meldingen). In RASFF is niet vermeld of het bij de meldingen van aflatoxinen in maïs ging om snijmaïs of korrelmaïs. In Nederland worden grondnoten (pinda's) en arachideolie niet verwerkt in diervoeder voor landbouwhuisdieren (SecureFeed gegevens). Geïmporteerde grondnoten(schilfers) worden met name gebruikt voor vogelvoer vooral voor tuinvogels (Frank Gort, persoonlijke communicatie). Het NP diervoeders laat echter weinig overschrijdingen zien van de $M L$ of richtwaarden: tussen 0 en $0.47 \%$ van de monsters in de periode 2011-2016. In de meeste gevallen betrof het DON en ZEA. Aflatoxine B1 werd eenmaal aangetroffen in een monster pindaolie in 2011 en eenmaal in een monster maïs in 2013.

a. Primaire plantaardige productie

Mycotoxines komen voor een groot aantal primaire plantaardige producten voor voedergewassen, met name in graansoorten (in tarwe, gerst, haver, maar minder in triticale, en maïs). De aanwezigheid en type mycotoxine varieert tussen graansoort en regio waarin het gewas verbouwd wordt. Zo komen in korrelmaïs geteeld in gebieden met een (sub)tropisch klimaat met name aflatoxines voor. In granen die in gebieden met een gematigd klimaat verbouwd worden zoals Noordoost Europa en Canada, zijn regelmatig besmet met Fusarium mycotoxines. Veldstudies in Nederland tussen 2001 en 2016 laten zien dat de mediaanwaarde voor DON in tarwe varieert van $100 \mu \mathrm{g} / \mathrm{kg}$ tot $1250 \mu \mathrm{g} / \mathrm{kg}$. In grassen en snijmaïs komen mycotoxines in mindere mate voor tijdens de teelt. In voederbieten, erwten, bonen en lupinen is de aanwezigheid verwaarloosbaar. Wel moet opgemerkt worden dat de hoeveelheid data over voorkomen van mycotoxines in deze producten zeer gering is. Bedorven zoete aardappel (bataat) kan Fusarium solani bevatten, een schimmel die furanen, zoals 4-ipomeanol produceert. Wanneer koeien dit binnenkrijgen, kan dit fataal zijn (Constable et al., 2016). De schimmel kan ook suikerbiet infecteren en ziekte van de plant veroorzaken (Majumdar et al., 2008). Er is geen literatuur bekend over de productie van mycotoxines in suikerbieten.

In een studie naar het optreden van mycotoxinen in voer voor melkveekoeien in Nederland (Driehuis et al., 2008), werd met name DON en zearalenone aangetroffen. De incidentie van, respectievelijk, DON en zearalenone in kuilvoer (gras en mais), krachtvoer en grondstoffen lag tussen $38-54 \%$ en 17-38\%. Daarnaast werd in kuilvoer en ingekuilde bijproducten roquefortine $\mathrm{C}$ en mycophenolic acid gevonden, met een incidentie van 7-19\%. De gemiddelde en maximale concentraties in volledige 
voeders voor melkvee lagen op 273 en $969 \mu \mathrm{g} / \mathrm{kg}$ voor DON en op 28 en $203 \mu \mathrm{g} / \mathrm{kg}$ voor zearalenone. Voor elk van de vier mycotoxinen, droeg mais kuilvoer het meeste bij aan de blootstelling van de melkkoeien. Aangezien de overdracht van deze vier mycotoxinen naar melk laag is, concludeerden de auteurs dat het risico voor de mens laag is.

b. Invoer, import en verwerking plantaardige producten niet voedergewassen, $1^{\mathrm{e}}$ fase

Tijdens het verwerken van granen, bijvoorbeeld in maalderijen, ontstaan verschillende fracties van het graan. Mycotoxines hopen zich met name op in de buitenste fracties van de korrel, dus in vezels en schilletjes, en zijn minder aanwezig in het endosperm van het graan. Dit kan dus een risico vormen voor diervoeder, omdat daarin juist deze buitenste fracties worden verwerkt. Bierbostel, een bijproduct van mouterijen, wordt als (onderdeel van) brijvoer gevoerd aan dieren. In de productie van bio-ethanol ontstaat DDGS als bijproduct, dat vaak afgezet wordt in de diervoederindustrie. Door de concentratie van de mycotoxines in DDGS (ca 3 maal t.o.v. de concentratie in de grondstof) kan het hoge gehalten aan mycotoxines, zoals DON, bevatten. In de monitoringsgegevens van het NP diervoeders tussen 2012 en 2016, opgeslagen in KAP, zijn bijna geen overschrijdingen van de limiet voor aflatoxine of DON in DDGS ( 0 van 2 metingen) of in brijvoer voor varkens ( 0 van 21 metingen voor aflatoxine, 1 van 56 metingen voor DON) gevonden.

Patuline is het enige mycotoxine dat gerapporteerd wordt in appels, maar appels worden vrijwel niet gebruikt in diervoeders. Het voorkomen van mycotoxines in overige groente- en fruitproducten lijkt minimaal. Diacetoxyscirpenol kan voorkomen in aardappelen (Shams et al., 2011).

Trendanalyses aan de hand van KAP-gegevens over de periode 2001-2009 laten zien dat er overschrijdingen van de ML zijn gevonden voor aflatoxinen in kokos(producten), aardnoten en zonnebloemzaad (Adamse et al., 2012). In de periode 2010-2016 werden in de KAP-gegevens alleen overschrijdingen voor aflatoxine gerapporteerd in mais (19 van 6848) en maisglutenvoermeel ( 1 van 227). Tevens waren er overschrijdingen voor DON in mais (10 van 2107), maisglutenvoermeel (13 van 253), tarwe (3 van 1782) en triticale (1 van 211). RASFF meldt tussen 2010 en 201649 notificaties gerelateerd aan aflatoxine in mais (46) en maisglutenvoermeel (3).

c. Verwerking plantaardige producten, $2^{\mathrm{e}}$ fase

In de verwerking van plantaardige producten in brood en banketbakkerijen, zoetwaren, alcoholindustrie en raffinage ontstaan zijstromen. Deze zijstromen kunnen mycotoxines bevatten. Als de grondstoffen voldoen aan de wettelijke limieten en tijdens productie van de levensmiddelen geen mycotoxinevorming optreed, dan is het aannemelijk dat de concentraties mycotoxinen in de reststromen ook lager zijn dan de wettelijke limieten. Als schimmelbesmetting optreedt bij de productie van de reststroom en als de opslagomstandigheden gunstig zijn voor mycotoxineproductie kunnen de reststromen besmet raken met mycotoxines. Data over incidentie en concentratie ontbreekt.

d. Verwerking plantaardige reststromen (voormalig levensmiddelen)

Aangenomen mag worden dat mycotoxines niet vaak voorkomen in voormalige levensmiddelen van plantaardige aard, gezien de over het algemeen strenge wettelijke eisen (limieten) die gesteld worden aan de aanwezigheid van mycotoxines in producten voor de humane consumptie.

e. Verwerking dierlijke producten, $1^{\mathrm{e}}$ en $2^{\mathrm{e}}$ fase

Gehalten aan mycotoxines in dierlijke producten, zoals zuivel en diermeel, zijn verwaarloosbaar laag. Voor zuivel zijn er geharmoniseerde limieten voor de aanwezigheid van aflatoxine $M_{1}$. In een recent verschenen EFSA opinie wordt wel melding gemaakt van de mogelijke aanwezigheid van zearalenon en metabolieten in melk (EFSA, 2016). Gegevens over het voorkomen van deze metabolieten in zuivel in Nederland ontbreken echter.

Mycotoxines hopen zich in het algemeen niet op in dierlijke producten, met uitzondering van het vetoplosbare ochratoxine A. Dit geldt ook voor de aanwezigheid van mycotoxines in vlees en vleeswaren waar in het algemeen gesproken wordt over ochratoxine $A$. 
f. Verwerking bijproducten tot voedermiddelen

Als schimmelbesmetting optreedt bij de productie van de reststroom en als de opslagomstandigheden gunstig zijn voor mycotoxineproductie kunnen de reststromen besmet raken met mycotoxines. Data over het optreden van mycotoxinen in reststromen ontbreken echter.

\section{g. Chemische productie additieven}

Van de besmetting van additieven met mycotoxinen is weinig bekend. In Verordening (EG) 1831/2003 is een groep van diervoederadditieven opgenomen beschreven als "stoffen voor het reduceren van de besmetting van diervoeder met mycotoxines; stoffen die de absorptie verminderen of onderdrukken, de uitscheiding door het dier vergroten, of de mode of actie veranderen".

\section{h. Productie mengvoeder}

Tijdens productie van mengvoeder zal het gehalte aan mycotoxines in de individuele grondstoffen niet afnemen. Het is bekend dat thermische processen geen invloed hebben op de concentraties. Wel kan door het mengen van ingrediënten het gehalte in het mengvoeder lager worden.

\subsubsection{Overdracht naar dierlijke producten}

Aflatoxine $B_{1}$ is carcinogeen en cytotoxisch voor mens en dier. Herkauwers zijn in staat aflatoxine $B_{1}$ vanuit diervoeder om te zetten in aflatoxine $M_{1}$, dat ook toxisch is en actief via de melk wordt uitgescheiden (Hussein and Brasel, 2001). De overdracht van aflatoxine $B_{1}$ uit het diervoeder in de vorm van aflatoxine $M_{1}$ in melk van melkgevende runderen ligt tussen 2-6\% (van der Fels-Klerx and Camenzuli, 2016). Overdracht van aflatoxine $B_{1}$ zelf naar overige dierlijke producten, zoals eieren en melk, is laag.

Ochratoxine $\mathrm{A}$ is goed oplosbaar in vet en kan worden opgeslagen in dierlijk vet en in de lever (Battacone et al., 2010). In diervoeder ingrediënten van dierlijke oorsprong, zoals varkenslever, nieren en vlees, en kippenlever, zijn gehalten tussen 0.1-1 ng/g gevonden (Malir et al., 2016). Ochratoxine A kan ook worden aangetroffen in bloed en overdracht naar de melk is mogelijk (FloresFlores et al., 2015), maar aan de lage kant.

Overdracht van Fusarium mycotoxines, zoals DON en ZEA, van voeder, via dier naar dierlijke producten, zoals vlees, lever en melk, lijkt zeer beperkt. ZEA wordt door het dier snel omgezet in metabolieten (e.g. a en $\beta$-zearalenol) en uitgescheiden. Voor ZEA en metabolieten is beperkte data aanwezig over mogelijke overdracht naar dierlijke producten. Van de geteste weefsels, wordt ZEA het meest gevonden in de lever (varkens en kippen) en melk en vlees (koeien), maar de overdrachtsfactor was in het algemeen laag, < 0.03 (EFSA, 2016a). Er lijkt geen overdracht te zijn naar eieren. De beperkte data van gehalten in dierlijke producten lieten zien dat ZEA en metabolieten gehalten erg laag waren. EFSA concludeerde dan ook dat de mogelijke bijdrage van ZEA en residuen via dierlijke producten verwaarloosbaar is ten opzichte van de totale blootstelling via voedsel consumptie. Gezien geringe beschikbaarheid van data vraagt EFSA wel meer aandacht voor a- zearalenol (EFSA, 2016). Doordat het percentage plantaardige ingrediënten in visvoer de laatste jaren toeneemt, wordt kweekvis meer blootgesteld aan chemische gevaren die kunnen voorkomen in plantaardige producten. Visvoer kan daardoor ook mycotoxines bevatten. Een recente studie laat zien dat indien visvoer mycotoxines bevat, deze niet worden overgedragen naar de eetbare delen in zalm en zeebrasem (Nácher-Mestre et al., 2015).

\subsubsection{Regulering}

In Europa is de maximale aanwezigheid van aflatoxine $B_{1}$ en ergot alkaloïden in de vorm van sclerotia in diervoeder en -ingrediënten wettelijk gereguleerd (Richtlijn 2002/32/EG). Dit vanwege de hoge toxiciteit van aflatoxine $B_{1}$ voor mens en dier, en de metabolisatie van aflatoxine $B_{1}$ naar aflatoxine $M_{1}$ in de lever en vervolgens de (gedeeltelijke) uitscheiding van aflatoxine $M_{1}$ in de melk van melkgevende dieren (runderen, schapen en geiten). De maximale limiet varieert van $0,005 \mathrm{mg} / \mathrm{kg}$ (bij $12 \%$ droge stof) voor complete diervoeders voor melkvee tot $0,02 \mathrm{mg} / \mathrm{kg}$ voor een aantal andere diervoeders. Voor een aantal andere mycotoxines zijn er in Europa aanbevelingen vastgelegd voor diervoeders voor verschillende diersoorten (Aanbeveling 2006/576/EG). Dit betreft deoxynivalenol, zearalenon, ochratoxine $A$, en de som van fumonisine $B_{1}$ en $B_{2}$. Deze mycotoxines kunnen een risico vormen voor de diergezondheid en de dierlijke productie van een aantal diersoorten negatief beïnvloeden. Het risico voor de mens is echter laag; de aanwezigheid van deze mycotoxines in producten van dierlijke oorsprong draagt slechts marginaal bij aan de totale humane blootstelling aan 
deze toxinen via consumptie (die met name door graanproducten wordt bepaald). Daarnaast is er een advieslimiet voor de aanwezigheid van T-2/HT-2 toxinen in kattenvoer van 0,005 mg/kg. De Nederlandse diervoederindustrie hanteert in verband met effecten op de dierlijke productie vaak eigen, strengere normen, en controleert zelf op de aanwezigheid van de mycotoxines. Voor aflatoxine $B_{1}$ heeft SecureFeed een afkeurgrens van 0,0025 mg/kg en een actiegrens van 0,002 $\mathrm{mg} / \mathrm{kg}$ voor melkveevoeder, te weten mengvoeders en enkelvoudige aflevering aan veehouders (helft van de wettelijke limiet). Daarnaast hanteert zij een actiegrens van $0,0025 \mathrm{mg} / \mathrm{kg}$ voor aflatoxine $B_{1}$ in overige diervoeders; de afkeurgrens voor overige diervoeders ligt op de ML (SecureFeed, 01-09-2016). Volgens Richtlijn 2002/32/EG is het mengen van diervoeders met dezelfde of andere producten om zo de gehalten van mycotoxines (en andere gereguleerde contaminanten vastgelegd in deze wet) te verlagen niet toegestaan. Voor wat betreft mycotoxines geldt dit dus alleen voor aflatoxine $B_{1}$. Het mengen is dus niet verboden als het gaat om diervoeders waarvan de Europese adviesnormen voor één of meerdere van de andere zes mycotoxines (deoxynivalenol, zearalenon, ochratoxine $A$, en fumonisine $B_{1}$ en $B_{2}, T-2$ toxine en HT-2 toxine) worden overschreden.

Aanbeveling 2006/576/EG bevat adviesgehalten voor deoxynivalenol, zearalenon, T-2/HT-2 toxine, ochratoxine A en fumonisines. Deze adviesgehaltes worden in het algemeen als wettelijke limieten in diervoeders gehanteerd.

Recente ontwikkeling op gebied van regulering van mycotoxines zijn de voorstellen van EFSA voor group health based guidance values (HBGV) voor mycotoxines en hun gemodificeerde vormen (EFSA, 2014). HBGV geven de maximaal aanvaardbare orale inname aan voor de mens voor groepen van stoffen c.q. een stof en zijn metabolieten. De basis hiervoor is de aanname dat de gemodificeerde vormen in het maag-darmkanaal teruggevormd kunnen worden naar het uitgangsmycotoxine waardoor de blootstelling aan het uitgangsmycotoxine verhoogd is. EFSA heeft voor zearalenon, T-2 toxine, HT-2 toxine en voor DON en hun gemodificeerde vormen al een opinie uitgebracht met een voorstel voor een group HBGV (EFSA, 2016, 2017a).

\subsubsection{Conclusie}

Ongeveer de helft van alle RASFF-meldingen zijn voor aflatoxines in plantaardige producten. Gegevens van de Nationale monitoring laten geen hoge percentages overschrijdingen zien, maar er zijn wel overschrijdingen gevonden voor aflatoxinen in mais(producten), kokos(producten), aardnoten en zonnebloemzaad. Omdat de overdracht van aflatoxinen in diervoeder naar melk mogelijk is en gezien de toxiciteit van aflatoxine $M_{1}$ voor de mens, worden aflatoxines, met name aflatoxine $B_{1}$, opgenomen op de short-list van diervoeder. Voor a-zearalenol in melk is meer onderzoek gevraagd door EFSA.

\subsubsection{Planttoxines}

\subsubsection{Algemeen}

Planten produceren een groot aantal metabolieten waarvan sommige niet essentieel zijn voor het overleven van het organisme, de zgn. secundaire metabolieten. Secundaire metabolieten met negatieve effecten op de gezondheid van mens en/of dier worden planttoxines genoemd, of onder de verzamelnaam natuurlijke toxinen aangeduid. De variatie in de moleculaire structuren van deze secundaire metabolieten is groot (Frohne and Pfänder, 2005). Planten uit de familie van de Fabaceae (soja, lupine, peulvruchten) bevatten anti-nutritionele factoren (ANF). ANF zijn stoffen die een negatief effect hebben op de vertering in het maag-darmstelsel. Soja en lupine worden vaak gebruikt in mengvoeders voor landbouwhuisdieren en vissen nadat ze een behandeling ondergaan hebben om ANF-gehalten te verlagen (Gatta et al., 2013; Lim et al., 2010; Werneck de Carvalho et al., 2013). Restmaterialen van de biobrandstofproductie, zoals perskoeken of meel uit bijvoorbeeld koolzaad bevatten meestal ook ANF en moeten voor gebruik worden bewerkt (FAO, 2012; Panda and Sastry, 2007). Terwijl sommige giftige planten wereldwijd voorkomen zijn andere beperkt tot bepaalde geografische gebieden (FitzGerald et al., 2011). Concentraties van plantaardige gifstoffen kunnen variëren tussen species, seizoenen en jaren, waardoor schattingen van concentraties lastig zijn te maken (Cook et al., 2015; Pfister et al., 2011; Schimming et al., 2005). Er zijn honderden planten met toxinen gerapporteerd die relevant voor de diergezondheid zouden kunnen zijn. Planttoxines kunnen bij landbouwhuisdieren leiden tot acute sterfte, maar in het algemeen beïnvloeden ze de productie negatief, door effecten zoals verminderde vruchtbaarheid, geboorteafwijkingen, gereduceerd 
gewicht en immunomodulatie (Chenchen et al., 2014; Devanaboyina et al., 2007; Diaz et al., 2014; Dierengezondheidszorg_Vlaanderen_(DGZ), 2013; Fink-Gremmels, 2012; Gatta et al., 2013; Welch et al., 2014; Wocławek-Potocka et al., 2013). Planttoxines komen voor in planten die door dieren niet gegeten worden, zoals bepaalde onkruiden in grasland en hooilanden, maar kunnen ook voorkomen in kruiden die wel door dieren gegeten worden. In Nederland is de belangrijkste route van de blootstelling van dieren aan ongewenste planten via ruwvoer, vers zowel als kuilvoer (van Raamsdonk et al., 2015). Via deze route worden met name grazers als rundvee, schapen en geiten blootgesteld. Hooi afkomstig van ruig, nat grasland heeft in 2013 in België geleid tot sterfte van 30 ooien door de aanwezigheid van Galaga officinalis in het hooi, een uitheems kruid in België (Dierengezondheidszorg_Vlaanderen_(DGZ), 2013). Ook is bekend dat de pyrrolizidine-alkaloïden (PA's) uit het Jacobskruid en andere kruiskruiden giftig zijn voor diverse landbouwhuisdieren (o.a. paarden). In de weide grazen de dieren om het Jacobskruid heen maar in de gedroogde vorm, hooi, wordt het niet herkend door de dieren.

Planttoxines kunnen ook voorkomen in restmaterialen zoals raapzaadmeel (Quiniou et al., 2012) en in zeer zeldzame gevallen in het drinkwater (Bonadies et al., 2011). Blootstelling kan ook plaatsvinden via mengvoeder waaraan kruiden zijn toegevoegd om de smaak te verbeteren, zogenoemde sensoriële additieven en via kruiden(mengsels) die gebruikt worden om de gezondheid van de dieren te bevorderen (Benchaar et al., 2008; Hashemi and Davoodi, 2011). Een vrijwel theoretische blootstellingsroute is via residuen van gewasbeschermingsmiddelen op basis van plantenstoffen zoals azadirachtine, karvon, pyrethrines en nicotine.

\subsubsection{Aanwezigheid planttoxines in sub-ketens}

RASFF geeft 20 meldingen voor planttoxines tussen 2005 en 2015: 13 voor gossypol, 17 voor Ambrosia-zaden en 4 voor cyanide. De meldingen betroffen gossypol in katoenzaad, Ambrosia-zaden in vogelvoer (meer dan de helft van de meldingen), in granen zoals maïs en sorghum en zaden van zonnebloemen) en cyanide in lijnzaad. Dit komt overeen met de resultaten van het NP Diervoeder ni de periode 2011-2016 waarbij Ambrosia regelmatig gevonden wordt in vogelvoer voor tuinvogels (tussen de 5 en 16\% van de monsters in de periode 2011-2016). Cyanide werd in lijnzaad gevonden tussen de 0 en 14\% van de monsters in de periode 2011-2016.

Er zijn geen normen voor PA's, maar ze worden wel regelmatig gevonden in diervoeder. Volgens het NP Diervoeder bevatte 4 tot 18\% van de monsters diervoeder in de periode 2011-2016 hoge concentraties PA's (> $1 \mathrm{mg} / \mathrm{kg}$ ). In een Nederlandse survey naar de aanwezigheid van PA's in ruwvoeders (kuilvoer, hooi, gedroogd gras en luzerne) werden in $21 \%(n=147)$ van de monsters sporen van PA's gevonden (LOD $10 \mu \mathrm{g} / \mathrm{kg}$ ) (Mulder et al., 2009). Circa 5\% van de 56 monsters kuilvoer bevatte lage concentraties PA'S, één monster hooi afkomstig uit een natuurgebied bevatte $549 \mu \mathrm{g} / \mathrm{kg}$ PA en één monster gedroogd gras $288 \mu \mathrm{g} / \mathrm{kg}$ PA. Van de 31 luzernemonsters bleek $74 \%$ (sporen van) PA'S te bevatten, 10\% van de monsters bevatte hoge concentraties PA'S (3,5, 3,8 en $5,4 \mathrm{mg} / \mathrm{kg}$ ). In de periode tussen januari 2014 en april 2015 werden PA'S aangetroffen in 6\% van de 183 monsters melk en $1 \%$ van de 205 monsters van eieren afkomstig uit de Europese retail (Mulder et al., 2015). In melkproducten, yoghurt, kaas en infant-formula, of vlees afkomstig van rund, varken, pluimvee of lever, werden geen PA'S in gehalten boven de detectielimiet aangetroffen.

Het beheersen van planttoxines in het dieet van landbouwhuisdieren in Nederland komt neer op goed graslandmanagement. Daarbij moet rekening gehouden worden met hooi of gedroogd gras dat afkomstig is uit gebieden of plaatsen die niet in eerste instantie bedoeld zijn voor grazers, zoals bijvoorbeeld wegbermen (DGZ, 2013; Mulder et al., 2009). Van belang is ook dat sommige dieren niet gevoelig zijn voor bepaalde planttoxines maar wel metabolieten kunnen overdragen in voedingsmiddelen van dierlijke oorsprong.

\section{a. Primaire plantaardige productie}

De gereguleerde planttoxines gossypol, waterstofcyanide, theobromine, vinylthiooxazolidon en vluchtige mosterdolie zijn inherent aanwezig in planten die gebruikt kunnen worden als diervoeder. De meeste van deze planten zijn uitheems voor Nederland en zullen niet direct gegeten worden door grazende dieren. De concentraties van de stoffen in de planten is afhankelijk van de omgevingsfactoren zoals temperatuur, beschikbare voedingsstoffen, insecten en competitie, en varieert tussen plantspecies, seizoenen en jaren. 
De zaden van Datura, Crotalaria, Ricinus communis, Croton tiglium, Abrus precatorius, Fagus sylvatica, Jatropha curcas, Ambrosia, Brassica juncea, Brassica nigra en Brassica carinata kunnen als onkruiden direct door grazende dieren geconsumeerd worden. Daarnaast kunnen ze als botanische besmetting mee geoogst worden of als reststroom tot diervoeders verwerkt zijn. Maximumgehalten voor deze zaden zijn opgenomen in Richtlijn 2002/32/EG. Het voorkomen van de (on)kruiden en dus planttoxines is afhankelijk van landbouwmanagement en omgevingsfactoren.

Ook de planttoxines uit niet-gereguleerde planten of de niet-gereguleerde planttoxines, zoals pyrrolizidine alkaloïden, kunnen voorkomen in diervoeder. Meestal als het gevolg van voorkomen van de planten in de graaslanden of mee-oogsten van de onkruiden.

b. Invoer, import en verwerking plantaardige producten niet voedergewassen, $1^{\mathrm{e}}$ fase Planttoxines kunnen in diervoeders aanwezig zijn als gevolg van inherent voorkomen in de plant of door mee-oogsten. Door verwerking van plantaardige producten en voedergewassen kan het gehalte aan planttoxines verlaagd worden door verdunning met andere grondstoffen.

Planttoxines zouden ook aanwezig kunnen zijn als botanische verontreiniging in kruiden zoals oregano en tijm die, meestal na droging, als voedermiddel worden gebruikt.

c. Verwerking plantaardige producten, $2^{\mathrm{e}}$ fase

Ricine dat nog aanwezig is in de perskoek van de Ricinus communis (voor biobrandstof) kan grotendeels geïnactiveerd worden door een hittebehandeling. Hetzelfde geldt voor de anti-nutritionele factoren die aanwezig zijn in peulvruchten. PA'S zijn erg stabiel en zullen bij verwerking, zoals drogen van hooi, niet in concentratie afnemen. Mogelijk wordt een deel afgebroken tijdens inkuilen.

d. Verwerking plantaardige reststromen (voormalig levensmiddelen)

Retourstromen van de brood- en banketindustrie of de alcoholindustrie zullen naar verwachting weinig tot geen planttoxines bevatten.

e. Verwerking dierlijke producten, $1^{\mathrm{e}}$ en $2^{\mathrm{e}}$ fase Het incident in Afghanistan heeft aangetoond dat de PA'S die aanwezig zijn in zuivel, stabiel zijn bij verwerking (Kakar et al., 2010a). Recent onderzoek (de Nijs et al., 2017) lijkt aan te tonen dat melkzuurbacteriën bij het maken van yoghurt en kaas het PA-gehalte van het eindproduct voor een deel kunnen verlagen t.o.v. de beginconcentratie.

f. Verwerking bijproducten tot voedermiddelen

Planttoxines, m.u.v. de vluchtige stoffen zoals alkenylbenzenen en cyanogene glycosiden (waaruit blauwzuur ontstaat) zijn stabiele componenten en zullen tijdens verwerking niet of nauwelijks afbreken. Fermentatie met melkzuurbacteriën lijkt wel enige reductie geven van gehalten. Indien bermgras gebruikt wordt voor grasraffinage, kunnen de bijproducten PA's bevatten.

g. Chemische productie additieven

Bij de chemische productie van additieven worden geen planten of kruiden gebruikt. Planttoxines zullen hierin dus niet voorkomen. In kruidenextracten zouden wel planttoxines kunnen voorkomen.

\section{h. Productie mengvoeder}

Naar verwachting ontstaan er geen additionele gevaren door het mengen van ingrediënten, verpakken en bewaren van mengvoeder. Mogelijk kan er verwisseling van ingrediënten optreden die kunnen leiden tot vergiftigingen. Dit is met name van belang voor zelfmengers. Eventuele lokale besmettingen kunnen 'verdund' worden door het mengen met schone ingrediënten.

\subsubsection{Overdracht naar dierlijke producten}

Overdracht van planttoxines naar voedingsmiddelen van dierlijke oorsprong komt voor, al is er weinig bekend over de orde van grootte waarin dit gebeurt. PA's kunnen bijvoorbeeld voorkomen in melk en eieren (Diaz et al., 2014; Dickinson et al., 1976; Hoogenboom et al., 2011; Mulder et al., 2015). De geschatte overdacht van PA's uit Jacobskruid naar melk in runderen ligt op 0,1\%. Dit kan een onderschatting zijn omdat er aanwijzingen dat de PA's gemetaboliseerd worden en dan ook uitgescheiden worden in de melk. Bij een incident in Afghanistan waarbij mensen overleden zijn aan PA-vergiftiging, met name na eten van besmet brood, bleek dat PA'S ook aangetroffen werden in een 
lokaal geproduceerde kaassoort (Kakar et al., 2010b). PA'S zijn stabiel in zuivel bij thermische processen, maar kunnen afnemen in het eindproduct als zuivel gefermenteerd wordt.

Van gossypol (katoenplant) is bekend dat het in lage hoeveelheden overgedragen kan worden naar plasma en melk (Wang et al., 2012). Overdracht van indospicine (Indigofera plant)(aminozuur, arginine analoog) naar vlees is gemeld in Australië (FitzGerald et al., 2011; Tan et al., 2014). Het is onbekend of deze planttoxine ook in Nederlandse weideplanten voorkomt of dat geïmporteerd vlees deze planttoxine bevat. Gezien de effecten van indospicine op de lever in dieren die blootgesteld zijn, zijn bij overdracht naar dierlijke producten, ook effecten op gezondheid van de consument te verwachten.

\subsubsection{Regulering}

$\mathrm{Er}$ is weinig bekend over het voorkomen van planttoxines in diervoeders. Meldingen in het RASFFsysteem (2005-2015) laten zien dat Ambrosia in diervoeder relatief vaak gemeld wordt. Hierbij is uitgegaan van de gereguleerde planttoxines en botanische verontreinigingen zoals weergegeven in de Richtlijn ongewenste stoffen in diervoeder (Richtlijn 2002/32/EG). Dit zijn vrij gossypol, waterstofcyanide, theobromine, vinylthiooxazolidon (5-vinyloxazolidine-2-thion) en vluchtige mosterdolie. Ook de (zaden van) een aantal planten worden hierin gereguleerd. Een tiental EUlidstaten ( $A, B, D, D K, F I, H U, N L, P, I R L, E S)$ heeft een actief monitoringsprogramma op de schadelijke botanische verontreinigingen uit deze richtlijn (van Raamsdonk, 2007). Gereguleerd zijn ook actieve stoffen voor gewasbescherming verkregen uit planten (Verordening (EG) 1107/2009).

\subsubsection{Conclusie}

PA's worden regelmatig aangetroffen in diervoeder, soms in hoge concentraties. Van de PA's is bekend dat ze kunnen worden overdragen naar melk, eieren en vlees en omdat een aantal PA's genotoxisch en carcinogeen zijn, komen ze op de short list met hoge prioriteit.

Voor bijvoorbeeld de cyanogene glycosiden is bekend dat ze in het dier worden omgezet naar blauwzuur en dat er geen overdracht is naar dierlijke producten.

Voor andere plant toxinen, te weten gossypol, Ambrosiazaden en cyanide, zijn RASFF-meldingen gevonden. Ook is overdracht naar dierlijke producten mogelijk, maar hierover is weinig bekend. Bovendien zijn er in het algemeen weinig gegevens over het voorkomen van planttoxines in diervoeders.

\subsubsection{Diergeneesmiddelen en coccidiostatica}

\subsubsection{Algemeen}

Diergeneesmiddelen omvatten middelen die stoffen bevatten zoals antibiotica en anthelminthica. Diergeneesmiddelen mogen slechts in de vorm van een gemedicineerd halffabricaat of voormengsel in gemedicineerde voeders worden verwerkt. Onder een voormengsel voor diervoeder met medicinale werking wordt verstaan: "elk geneesmiddel voor diergeneeskundig gebruik dat van tevoren is bereid om later te worden verwerkt in diervoeder met medicinale werking (Richtlijn 2001/82/EG". Een halffabricaat met medicinale werking is een voormengsel met medicinale werking met daarbij één of meer veevoedergrondstoffen, dat als zodanig is bestemd voor rechtstreekse verwerking in diervoeder. Premixen worden alleen op medisch attest gemaakt en voorgeschreven door de dierenarts.

In het verleden werden bepaalde antibiotica op grote schaal gebruikt als groeibevorderaar, waarbij sub-therapeutische niveaus aan diervoeder werden toegevoegd. Binnen de EU is het gebruik van deze antibiotica als groeibevorderaar niet meer toegestaan (Verordening (EG) 1831/2003), buiten de EU is dit echter nog altijd een wijdverspreid fenomeen. Het toevoegen van antibiotica aan diervoeders voor therapeutische toepassing is wel toegestaan. Om te mogen worden toegepast, dienen de antibiotica een formele registratie te hebben en ze mogen alleen op voorschrift van een dierenarts worden toegepast. In Tabel 9 is een overzicht gegeven van de diergeneesmiddelen (voornamelijk antibiotica) met een Nederlandse registratie (CBG 2016). 
Tabel 9 Diergeneesmiddelen met een Nederlandse registratie voor premix en/of topdressing (diergeneesmiddelendatabank College ter Beoordeling van Geneesmiddelen, CBG).

\begin{tabular}{lll} 
Diergeneesmiddel & Soort & Naam \\
Antibiotica & Marcroliden (inclusief lincosamiden en & Tiamulin \\
& pleuromutilines) & Tilmicosine \\
& & Tylosine \\
& & Tylvalosine \\
\cline { 2 - 3 } & Tetracyclines & Valnemulin \\
\cline { 2 - 3 } & Sulfonamides & Doxycycline \\
& & Oxytetracycline \\
\cline { 2 - 3 } & Beta-lactam & Sulfadiazine + trimethoprim \\
\cline { 2 - 3 } & Overig & Sulfamethoxazole + trimethoprim \\
\hline Anthelmintica & Amoxicilline \\
\hline & & Florfenicol \\
& & Colistine \\
\hline & & Amprolium \\
\hline
\end{tabular}

Productie van gemedicineerde diervoeders brengt een grote kans op besmetting van de volgende batch niet-gemedicineerd voeder met zich mee. Er is een kans op versleping wanneer gemedicineerde diervoeders op dezelfde productielijnen bereid worden als gewone diervoeders. Na het bereiden van een gemedicineerd voeder kunnen restanten van diergeneesmiddelen in de installatie achterblijven die in volgende partijen "blanco" diervoeders terechtkomen kunnen. Als "spoelvoeders" wordt veelal biggen- en zeugenvoer gebruikt omdat deze dieren geen "einddieren" zijn (ze worden niet direct geslacht voor vleesproductie) en hierdoor de kans op residuen in het vlees gering is. Nadeel is dat de dieren onbedoeld blootgesteld worden aan diergeneesmiddelen, weliswaar in een lage dosering, maar bijvoorbeeld in het geval van antibiotica kan een effect op resistentieontwikkeling niet worden uitgesloten. Een uitgebreide studie naar versleping (Stolker et al., 2013; Zuidema et al., 2010) toonde aan dat veel van deze zgn. 'spoelcharges' antibiotica bevatten in concentraties boven de door NVWA gehanteerde maximale carry-over limiet van 2,5\% van het laagste therapeutische niveau. Een recente inspectie door de NVWA liet zien dat een groot deel van het voer van de bedrijven die ook gemedicineerd voeder produceren meer dan 2,5\% versleping bevatte (NVWA, 2017a). Met het oog op deze problematiek en de mogelijke impact op de verspreiding van antibiotica resistentie, heeft de Nederlandse Vereniging Diervoederindustrie (NEVEDI) (circa 95\% van de totale diervoederproductie in Nederland) per 2012 besloten geen diervoeder met antibiotica meer te produceren (zowel mengvoeder als voormengsels en additieven) voor de Nederlandse markt (NEVEDI, 2011). Diergeneesmiddelen worden door de dierenarts voorgeschreven en door de veehouder met name via drinkwater maar ook via topdressing toegediend. Op attest van de dierenarts wordt nog wel mengvoeder met coccidiostatica of ontwormingsmiddelen geproduceerd. Ook vindt nog productie van gemedicineerde diervoeders voor exportdoeleinden plaats, bijvoorbeeld bestemd voor derde landen die eventueel middelen bevatten die niet in Nederland of in de EU zijn toegelaten, zoals het antibioticum carbadox. De producenten moeten dan kunnen aantonen dat zij voor export fabriceren en de mengvoeders moeten geëtiketteerd zijn met "export". De producent die hiervoor gecertificeerd is moet een strikt fysieke scheiding hanteren tussen de productielijnen waarop geen antibiotica verwerkt wordt en de lijnen waarop wel antibiotica wordt verwerkt (GMP+ International BCN NL 1). Ook voor import van in België en Duitsland geproduceerde gemedicineerde voeders is toestemming van een dierenarts noodzakelijk.

In 2015 werden er, ondanks het NEVEDI besluit, in zeven van 147 bemonsterde mengvoeders voor varkens (varkensbrok, bemonsterd bij varkenshouders) antibiotica aangetroffen in de volgende concentraties: oxytetracycline 14, 21 en $82 \mathrm{mg} / \mathrm{kg}$, doxycycline 0,31 en 0,26 mg/kg, sulfamethoxazole $<0,5 \mathrm{mg} / \mathrm{kg}$ en amoxicilline $0,1 \mathrm{mg} / \mathrm{kg}$ (NVWA, 2015). Gezien deze lage gehalten lijkt aanwezigheid van de gevonden antimicrobiële stoffen een gevolg te zijn van versleping. Therapeutische gehalten/doseringen van deze stoffen in voer zijn namelijk vele malen hoger. Onduidelijk is of dit in Nederland geproduceerde voeders betrof. Ook in monsters van brijvoeders 
(voeders op basis van vochtige bijproducten uit onder andere de voedingsmiddelenindustrie), genomen bij veehouderijbedrijven worden met enige regelmaat antibiotica aangetroffen. In 2015 werd in twee van de 81 geanalyseerde varkensvoeren sulfadiazine $(<0,5 \mathrm{mg} / \mathrm{kg})$ en een combinatie van doxycycline $(0,47 \mathrm{mg} / \mathrm{kg})$ en amoxicilline $(<0,1 \mathrm{mg} / \mathrm{kg})$ aangetroffen (NVWA, 2015). Het eerder genoemde NEVEDI-convenant heeft overigens geen betrekking op brijvoeders, deze kunnen op de boerderij (op veterinair attest) met daarvoor geregistreerde antibiotica worden gemedicineerd door de veehouder.

In opgeloste (aangelengde) kunstmelkpoeders uit de vleeskalversector zijn in 2015 een aantal keer antibiotica (vrijwel uitsluitend tetracyclines) aangetroffen, waarvan mag worden aangenomen dat deze doorgaans afkomstig zijn van toevoeging van een diergeneesmiddel. Er werden echter ook in het uitgangsmateriaal kunstmelkpoeder residuen aangetroffen die mogelijk ten gevolge van versleping in de poeders waren terechtgekomen. Ook door het vervoederen van zogenaamde "waste milk"; melk afkomstig van met diergeneesmiddelen behandeld melkvee, kunnen dieren onbedoeld worden blootgesteld aan diergeneesmiddelen. De melk die geproduceerd wordt binnen de wachttermijn mag niet worden aangeboden voor humane consumptie, en wordt vaak uit economische overwegingen aan jongvee vervoederd. Over de omvang hiervan in Nederland zijn geen gegevens bekend. Een in het Verenigd Koninkrijk uitgevoerde survey op aanwezigheid van beta-lactam antibiotica laat zien dat in "waste milk' hoge gehalten beta-lactam antibiotica kunnen worden aangetroffen (Randall et al., 2014).

Een nog beperkt onderzochte bron van introductie van antibiotica in de diervoederketen is afkomstig van gehydrolyseerde eiwitten, zoals verenmeel. Recent onderzoek in de Verenigde Staten toonde de aanwezigheid van onder andere antibiotica aan in, met name, uit China afkomstige producten (Love et al., 2012). De gevonden gehalten varieerden van een laag $(\mu \mathrm{g} / \mathrm{kg}$ ) niveau tot $1050 \mu \mathrm{g} / \mathrm{kg}$

(enrofloxacin). Er werd een aantal antibiotica aangetroffen die in de EU niet zijn toegelaten: ofloxacin, azitromycine, ormetoprim en virginiamycin, maar ook relatief hoge concentraties van het in de EU wel toegelaten thiabendazole (fungicide). In 2015 zijn binnen het Nationaal Plan Diervoeder tien monsters verenmeel onderzocht, waarvan er zeven antibiotica bleken te bevatten: enrofloxacin $(45 \mu \mathrm{g} / \mathrm{kg})$, tiamulin $(26 \mu \mathrm{g} / \mathrm{kg}$ ), sulfadiazine (gehalten variërend tussen $10-130 \mu \mathrm{g} / \mathrm{kg}$ ) en sulfadimethoxine $(36 \mu \mathrm{g} / \mathrm{kg}$ ). Chlooramfenicol en coccidiostatica zijn in deze monsters niet aangetroffen (NVWA, 2015).

\section{Verboden antibiotica}

Een aantal antimicrobiële stoffen zijn in de EU (en veel andere landen) expliciet verboden voor gebruik in voedselproducerende dieren. Deze stoffen staan vermeld in Tabel 2 van de bijlage van Verordening (EU) 37/2010 en betreffen - onder andere - chlooramfenicol, nitrofuranen en metronidazol (Verordening (EU) 37/2010). Residuresten van verboden antibiotica zijn veelal een gevolg van besmette diervoedergrondstoffen en -additieven. In 2014 betrof een RASFF-melding, nitrofuranen in krachtvoer uit Nederland. In 2013 waren er 12 RASFF-meldingen over de aanwezigheid van het verboden antibioticum chlooramfenicol in enzympreparaten bedoeld voor de productie van diervoeders. Gerapporteerde gehalten varieerden van $0,13 \mu \mathrm{g} / \mathrm{kg}$ tot $47000 \mu \mathrm{g} / \mathrm{kg}$. Met name deze hoge gehalten leken te wijzen op opzettelijke toevoeging, vermoedelijk ter onderdrukking van ongewenste bacteriegroei in op gisten gebaseerde fermentatieprocessen. Soortgelijke problematiek was overigens in 2008 ook al aan de orde, toen er meerdere RASFF-meldingen over monensin (een polyether ionofoor, zie ook coccidiostatica) in gist opdoken. De bioethanolproductie waaruit deze reststroom afkomstig was maakte eveneens gebruik van antibiotica om besmetting met bacteriën te onderdrukken en de gistgroei te optimaliseren. Hoewel bovengenoemde incidenten steeds betrekking hadden op één specifieke antibacteriële stof, kunnen mogelijk ook andere antibiotica toegevoegd worden aan fermentatie processen met schimmels/gisten. In 2014 heeft zich in Nederland een incident met furazolidon besmet diervoeder voorgedaan. De besmetting bleek terug te traceren naar een handelaar in diervoedergrondstoffen, maar de exacte oorzaak van de aanwezigheid van furazolidon in het voeder is echter nooit opgehelderd.

Chlooramfenicol wordt geproduceerd door bodembacteriën (onder andere door Streptomyces venezuela) en komt daardoor mogelijk ook via een natuurlijke route in de diervoederketen. Een studie met maïs en tarwe heeft aangetoond dat chlooramfenicol door planten wordt opgenomen (Berendsen et al., 2013a), wat verklaart dat chlooramfenicol veelvuldig in producten als stro wordt aangetroffen (Nordkvist et al., 2016). Gevonden gehalten liggen over het algemeen op een laag (zelfs sub $\mu \mathrm{g} / \mathrm{kg}$ ) niveau, met uitschieters tot $32 \mu \mathrm{g} / \mathrm{kg}$ (Nordkvist et al., 2016). Het is tot dusver onduidelijk in welke 
mate er vanuit deze voedermatrix overdracht naar dieren plaatsvindt. Lage concentraties (tot $50 \mu \mathrm{g} / \mathrm{kg}$ chlooramfenicol) in kippenvoer leiden niet tot residuen in het vlees (Rejtharova et al., 2017). Echter, een dagelijkse orale dosis $40 \mu \mathrm{g}$ chlooramfenicol per varken gedurende 14 dagen, leidt tot residuen boven de MRPL in weefsels (uitgezonderd de spieren) van varkens (Aspenström-Fagerlund et al., 2016). Natuurlijke concentraties in stro kunnen dus leiden tot een overschrijding van de MRPL in dierlijke producten. Gezien het voorkomen in stro, zou chlooramfenicol ook van nature kunnen voorkomen in gras. Hier zijn echter geen gegevens over.

\section{Coccidiostatica}

Coccidiostatica zijn middelen die worden toegepast ter voorkoming en genezing van infecties met eencellige darmparasieten (coccidia). In tegenstelling tot antibiotica mogen deze middelen zonder tussenkomst van een dierenarts worden gebruikt, omdat ze worden gezien als diervoederadditieven. Deze middelen dienen wel geregistreerd te staan in het register voor additieven voor diervoeder (Verordening (EG) 1831/2003). Een overzicht van de hierin opgenomen coccidiostatica staat vermeld in Tabel 10.

Tabel 10 Diervoederadditieven (Verordening (EG) 1831/2003).

\begin{tabular}{lll} 
Diervoederadditief & Soort & Naam \\
Coccidiostatica & Inoforen & Lasalocid A sodium \\
& & Maduramicin \\
& & Monensin sodium \\
& & Narasin \\
& Salinomycin \\
\cline { 2 - 3 } & Overig & Semduramicin \\
& & Decoquinate \\
& Diclazuril \\
& Halofuginone \\
& Nicarbazin \\
& Robenidine \\
\hline
\end{tabular}

Coccidiostatica-bevattende voeren worden op grote schaal geproduceerd voor toepassing bij pluimvee (vleeskuikens en legkippen voor de leg) en konijnen. Maximale gehalten van toegestane coccidiostatica in niet-doeldiervoeders als gevolg van niet te voorkomen versleping staan vermeld in Afdeling VII van Bijlage I van Richtlijn 2002/32/EG. Deze normstelling heeft in de eerste plaats als doel het voorkomen van residuen in dierlijke producten, en ten tweede het voorkomen van toxische effecten in bepaalde niet-doeldieren, dit omdat met name ionoforen toxisch zijn voor bepaalde nietdoeldieren zoals paarden.

Data uit Nationaal Plan Diervoeders laten zien dat versleping van coccidiostatica (in doeldiervoeders) veelvuldig optreedt ( $50 \%$ van de monsters in 2014, 49\% in 2015), maar dat het aantal niet-conforme bevindingen beperkt is (2\% in 2014, 3\% in 2015) (NVWA, 2014, 2015).

\section{Anthelmintica}

In Nederland mogen alleen de anthelmintica (ontwormingsmiddelen) flubendazole en ivermectine via het voer worden toegediend. Voor beide geldt dat dit slechts op voorschrift van een dierenarts is toegestaan. Alleen flubendazole is opgenomen in het Nationaal Plan Diervoeders en voor deze stof hanteert de NVWA een verslepingsnorm van 2,5\% (doeldieren) of $1 \%$ (niet-doeldieren).

Monitoringresultaten tonen aan dat besmetting met deze residuen minimaal is: in 2014 werd in geen enkel van de 114 onderzochte diervoedermonsters flubendazole aangetroffen, en in 2015 werd in één van de 137 monsters 0,3 mg/kg flubendazole gevonden (NVWA, 2014, 2015).

\subsubsection{Aanwezigheid diergeneesmiddelen in sub-ketens}

De RASFF-databank geeft 62 meldingen voor (residuen van) diergeneesmiddelen in producten bestemd om te vervoederen tussen 2005 en 2015. De categorie diergeneesmiddelen beslaat minder dan $2,5 \%$ van alle RASFF-meldingen met betrekking tot diervoeder (diervoeder, additieven, 
diervoedermaterialen, voormengsels). De meeste van deze meldingen betrof chlooramfenicol (23 meldingen). Een relatief groot deel van de RASFF-meldingen (18 meldingen) betrof coccidiostatica (salinomycine, narasin, lasalocide en amprolium). Het laatst genoemde coccidiostaticum valt onder de diergeneesmiddelenwetgeving. Daarnaast waren er nog meldingen voor tetracyclines ( 5 meldingen voor oxytetracycline en 5 voor tetracycline). Chlooramfenicol werd vooral gevonden in vitamines en enzympreparaten (xylanase). Salinomycine werd vooral in aanvullend diervoeder gevonden en tetracyclines vooral in visvoer.

a. Primaire plantaardige productie

Een therapeutische behandeling met diergeneesmiddelen resulteert doorgaans in het uitscheiden van hoge concentraties residuen via urine en feces. Het gebruik van dierlijke meststoffen in de akkerbouw kan daarmee een bron van bodem, oppervlakte- en grondwaterbesmetting vormen (Hamscher et al., 2005). Residuconcentraties in de bodem zijn, naast de initiële concentratie in de mest, sterk afhankelijk van de stabiliteit en fysisch-chemische karakteristieken van de stof (Pikkemaat et al., 2016). Theoretisch kunnen via deze route residuen van diergeneesmiddelen in plantaardige producten terecht komen. Een studie met maïs en tarwe heeft aangetoond dat in de bodem aanwezige chlooramfenicol door planten wordt opgenomen (Berendsen et al., 2013a). Ook van tetracycline en amoxicilline is bekend dat deze door planten kunnen worden opgenomen (Azanu et al., 2016). Voor het overgrote deel van de diergeneesmiddelen zijn echter geen gegevens bekend. Voor een beperkt aantal antibiotica kan daarnaast de mogelijkheid dat deze via natuurlijke productie door bodembacteriën in planten terecht komen, niet worden uitgesloten (Berendsen et al., 2013a). Het is onwaarschijnlijk dat dit in hoge $(\mathrm{mg} / \mathrm{kg}$ ) residuconcentraties in plantaardig materiaal resulteert.

b. Invoer, import en verwerking plantaardige producten niet voedergewassen, $1^{\mathrm{e}}$ fase Niet relevant.

c. Verwerking plantaardige producten, $2^{\mathrm{e}}$ fase

Het is niet aannemelijk dat in dit stadium van het productieproces additionele besmetting met diergeneesmiddelen optreedt. Wel is het mogelijk dat residuen uit de primaire productie worden afgebroken onder invloed van bijvoorbeeld verhitting. De stabiliteit van diergeneesmiddel residuen verschilt echter sterk per stof.

d. Verwerking plantaardige reststromen (voormalig levensmiddelen) -

e. Verwerking dierlijke producten, $1^{\mathrm{e}}$ en $2^{\mathrm{e}}$ fase De aanwezigheid van residuen van diergeneesmiddelen in veren, en mogelijk ook producten als beendermeel en eierschalen, vormen een potentiële bron van herintroductie in de diervoederketen. Met name wanneer deze grondstoffen afkomstig zijn uit gebieden waar het gebruik van groeibevorderaars is toegestaan, of een bovenmatig gebruik van therapeutische antibiotica gangbaar is, bijvoorbeeld zoals in Zuidoost Azië, is het zelfs onwaarschijnlijk dat dit volledig "schone" producten betreft.

f. Verwerking bijproducten tot voedermiddelen

Een potentieel gevaar vormt het gebruik van reststromen uit de bioethanolproductie (Dried Distiller Grain Solubles). Het is niet ongebruikelijk dit fermentatieproces te optimaliseren door bacteriegroei remmende stoffen (i.e. antibiotica) toe te voegen. De kans op aanwezigheid van residuen in deze reststroom is onder andere afhankelijk van de stabiliteit van het gebruikte antibioticum en eventuele verdere verwerking van het product.

g. Chemische productie additieven

Net als de eerder genoemde bioethanolproductie, is ook de productie van enzymen en sommige vitamines gebaseerd op een fermentatieproces waarbij mogelijk bacteriegroeiremmende stoffen worden gebruikt. De enzymen worden aan diervoeder voor pluimvee en varkens toegevoegd om de voederconversie te optimaliseren, maar worden ook voor non-food/feed doeleinden geproduceerd. 


\section{h. Productie mengvoeder}

Gevaren bij de productie van mengvoeder zouden kunnen voorkomen als gevolg van carry-over uit eerder geproduceerde gemedicineerde batches. Echter, de productie van met antimicrobiële stoffen gemedicineerde voeders op reguliere productielijnen is in Nederland niet langer gangbaar. In plaats van bij de veevoer producent worden tegenwoordig ook door de veehouder zelf antibiotica gedoseerd via drinkwater, brijvoeder of topdressing. Homogeniteit en juiste dosering kunnen dan reden tot zorg zijn. Het is niet bekend op welke schaal topdressing wordt toegepast.

\subsubsection{Overdracht naar dierlijke producten}

Voor geregistreerde diergeneesmiddelen zijn farmacokinetische studies beschikbaar waaruit gegevens over de overdracht naar dierlijke producten worden afgeleid. Indien een diergeneesmiddel via het voeder dient te worden toegediend moet de fabrikant van het middel een residustudie uitvoeren waarin het middel in de hoogst voorgestelde dosering in het voer en de langst voorgestelde toedieningsduur wordt toegediend aan doeldieren. Bij blootstelling aan residuen van diergeneesmiddelen in voeders door versleping is sprake van een veel lagere dan de therapeutische dosering; dit kan gevolgen hebben voor de farmacokinetiek van een stof. Om te voorkomen dat residuen van diergeneesmiddelen teruggevonden worden in dierlijke producten zijn wachttermijnen ingesteld waarbinnen dieren niet geslacht mogen worden en dierlijke producten niet verkocht mogen worden.

\subsubsection{Regulering}

Richtlijn 90/176/EEG bevat voorwaarden voor de bereiding, het in de handel brengen en het gebruik van diervoeders met medicinale werking. Deze richtlijn is in Nederland geïmplementeerd in de Wet dieren en daarbij horende besluiten en regelingen. Daarnaast zijn er binnen Europese wetgeving en ook binnen GMP+ verslepingsnormen vastgesteld.

Gemedicineerde voeders mogen uitsluitend worden gemaakt door producenten die hiervoor een vergunning hebben. Daarbij mag alleen gebruik gemaakt worden van voormengsels waarvoor een handelsvergunning is afgegeven. Voordat een handelsvergunning kan worden afgegeven voor voormengsels bedoeld voor het maken van gemedicineerde voeders voor voedselproducerende dieren dient de werkzame stof in het voormengsel op EU niveau te zijn goedgekeurd en opgenomen te zijn in Tabel 1 van de bijlage van Verordening (EU) 37/2010. Bij de goedkeuring worden, indien nodig, MRL's vastgesteld voor gehalten aan residuen van de werkzame stof in dierlijke producten. Bij het op nationaal niveau verlenen van de handelsvergunningen worden voorschriften gegeven voor gebruik van de gemedicineerde voeders (onder andere gehalte werkzame stof in voeders, maximale toedieningsduur en aan te houden wachttermijn). Gemedicineerde voeders mogen uitsluitend op recept van een dierenarts aan een houder van dieren worden geleverd, de dierhouder dient de aanwijzingen van de dierenarts op te volgen bij gebruik van het voeder.

\subsubsection{Conclusie}

Er zijn overschrijdingen van diergeneesmiddelen gevonden, met name voor chlooramfenicol in vitamineen enzympreparaten en coccidiostatica. Residuen van diergeneesmiddelen kunnen verder in diervoeder terechtkomen via verwerking van plantaardige en dierlijke producten. Over het algemeen zijn gevonden gehalten laag en vormen ze geen gevaar voor de volksgezondheid. Het is niet bekend in welke mate topdressing wordt toegepast en of dit zou kunnen leiden tot residuen in dierlijke producten.

\subsubsection{Pesticiden}

\subsubsection{Algemeen}

Onder pesticiden worden in dit rapport de werkzame, chemische stoffen in gewasbeschermingsmiddelen en biociden bedoeld. Ook virussen of bacteriën kunnen gebruikt worden als pesticide maar deze worden in dit rapport buiten beschouwing gelaten. Pesticiden worden gebruikt in de akker- en tuinbouw ter bestrijding van bijvoorbeeld onkruid (herbiciden), schimmels (fungiciden) en ongedierte in gewassen (insecticiden, acariciden, rodenticiden). Landbouwhuisdieren worden blootgesteld aan (residuen van) pesticiden via diervoeder(ingrediënten). Een aantal pesticiden wordt ook toegepast als biocide (bijvoorbeeld ongediertebestrijding in en rond de dierverblijven) en als diergeneesmiddel. Voorbeelden van de laatste zijn pyrethroïden, organofosforpesticiden en carbamaten. Pyrethroïden, waaronder deltamethrin en cypermethrin, en de organofosforverbinding phoxim hebben in Nederland een toelating als diergeneesmiddel voor gebruik in landbouwhuisdieren, maar carbamaten zijn niet meer toegelaten. 
De gevaaranalyse in dit rapport beperkt zich tot blootstelling via diervoeder, waarbij pesticiden als residuen in de grondstoffen in de keten terecht komen. Er zijn meer dan 1500 stoffen bekend die gebruikt zijn of kunnen worden als pesticide. In de EU zijn voor gebruik in gewasbeschermingsmiddelen 481 actieve stoffen toegelaten. In Nederland bevatten de op de markt zijnde pesticiden in totaal 266 verschillende actieve stoffen (CTGB, juli 2016). Het aantal pesticiden dat in diervoeder kan worden aangetroffen beperkt zich niet alleen tot de in de EU toegelaten stoffen, omdat bepaalde diervoederingrediënten uit derde landen komen. In Zuid-Amerikaanse soja is bijvoorbeeld paraquat aangetroffen. Paraquat is in Zuid-Amerika toegelaten voor deze teelt en in Europa niet. Ook kunnen inmiddels verboden, persistente pesticiden nog in het milieu aanwezig zijn, en dus alsnog in de diervoederketen terecht komen. Het gaat hierbij vooral om organochloorpesticiden. Deze zijn lipofiel en kunnen met name via vetten en oliën in de diervoederketen terecht komen. Dit speelt ook bij diervoeder op basis van dierlijke producten (bijv. visolie).

\subsubsection{Aanwezigheid pesticiden in subketens}

Ten opzichte van agrarische producten voor humane consumptie wordt slechts een beperkt aantal producten voor diervoeder gemonitord op de aanwezigheid van residuen van pesticiden. In het kader van doorlopende programma Nationaal Plan diervoeder zijn in de periode 2011-juni 2016 circa 1600 monsters diervoeder of -ingrediënten geanalyseerd op pesticiden, voornamelijk met multiresidumethoden op basis van LC-MS/MS en GC-MS/MS. In 2017 worden 455 diervoeders breed gescreend op pesticiden (NVWA, 2017b). Naast deze monitoring door de overheid worden ook door de diervoedersector zelf monsters genomen en geanalyseerd, waarvan de resultaten deels gedeeld worden met de NVWA. Via SecureFeed zijn analysegegevens beschikbaar van ongeveer 675 monsters uit de periode 2010-2014. In deze monitoringsprogramma's van de overheid en de diervoedersector zijn 103 verschillende pesticiden aangetroffen, waarvan 73 stoffen minder dan tien keer. De meest frequent gevonden pesticiden (boven de rapportagegrens) staan vermeld in Tabel 11. Indien er een nultolerantie is voor de aanwezigheid in dierlijke producten (aangegeven met een $*$ ), dan is er of geen overdracht naar dierlijke producten of de stof mag niet gebruikt worden op gewassen die (ook) door landbouwhuisdieren worden gegeten. Onderzoek naar het voorkomen van pesticiden in diervoeder lijkt het meest relevant voor die pesticiden waarvoor gebruik en overdracht naar dierlijke producten dusdanig is dat het nodig werd geacht om MRL's in dierlijke producten vast te stellen (Tabel 11). Het aantal MRL-overschrijdingen in het NP diervoeder varieert tussen 0.4 en $3.9 \%$ in de periode 2011 2016. Hierbij moet opgemerkt worden dat diervoeder(grondstoffen) die uitsluitend gebruikt worden als diervoeder nog niet in detail zijn opgenomen in de productentabel behorende bij de MRL Verordening (EG) 396/2005. Voor al deze grondstoffen geldt dat er nog geen MRL's voor zijn vastgesteld voor alle residuen van actieve stoffen van gewasbeschermingsmiddelen genoemd in Verordening (EG) 396/2005 met uitzondering van de stoffen genoemd in Richtlijn 2002/32/EG.

In de monitoringsprogramma's van NP diervoeder en SecureFeed zijn niet altijd dezelfde pesticiden opgenomen, en worden pesticiden niet altijd in dezelfde mate gevonden. Dit kan komen door verschillen in de uitvoering tussen de private en de publieke monitoring. Chlormequat is onderdeel van de monitoring van SecureFeed terwijl de NVWA/RIKILT deze stof niet heeft opgenomen in haar monitoring; het omgekeerde geldt voor glyfosaat. De aanwezigheid van dichloorvos en didecyldimethylammonium chloride (DDAC) heeft geleid tot meldingen in RASFF. Dichloorvos is ook een enkele maal door RIKILT aangetroffen in diervoederproducten. DDAC is niet onderzocht in het kader van de Nederlandse programma's. De private en NVWA monitoringsprogramma's zijn niet alle jaren gelijk van inhoud, qua onderzochte diervoeders en voedermiddelen: aantallen monsters en herkomst van monsters variëren van jaar tot jaar, onder andere afhankelijk van budgettaire mogelijkheden en bevindingen in voorgaande jaren. Dit geldt ook voor de analysemethoden die worden gebruikt door de laboratoria die het onderzoek uitvoeren. Het aantal pesticiden dat is opgenomen in multi-residumethoden en de detectiegrenzen verschillen tussen laboratoria en tussen de jaren. De diversiteit in plantaardige voedermiddelen is enorm, de gebruikte grondstoffen en de herkomst veranderen in de tijd. Ook het gebruik van pesticiden in de productie van de verschillende plantaardige voedermiddelen verschilt per land en jaar. Dit bemoeilijkt trendanalyses en het voorspellen van issues. 
Tabel 11 Meest frequente meldingen van pesticiden in diervoeder/ingrediënten op basis van NVWA/RIKILT ( $n=$ ca. 1600) en SecureFeed monitoringsdata $(n=$ ca. 675) in de periode 2011-2016.

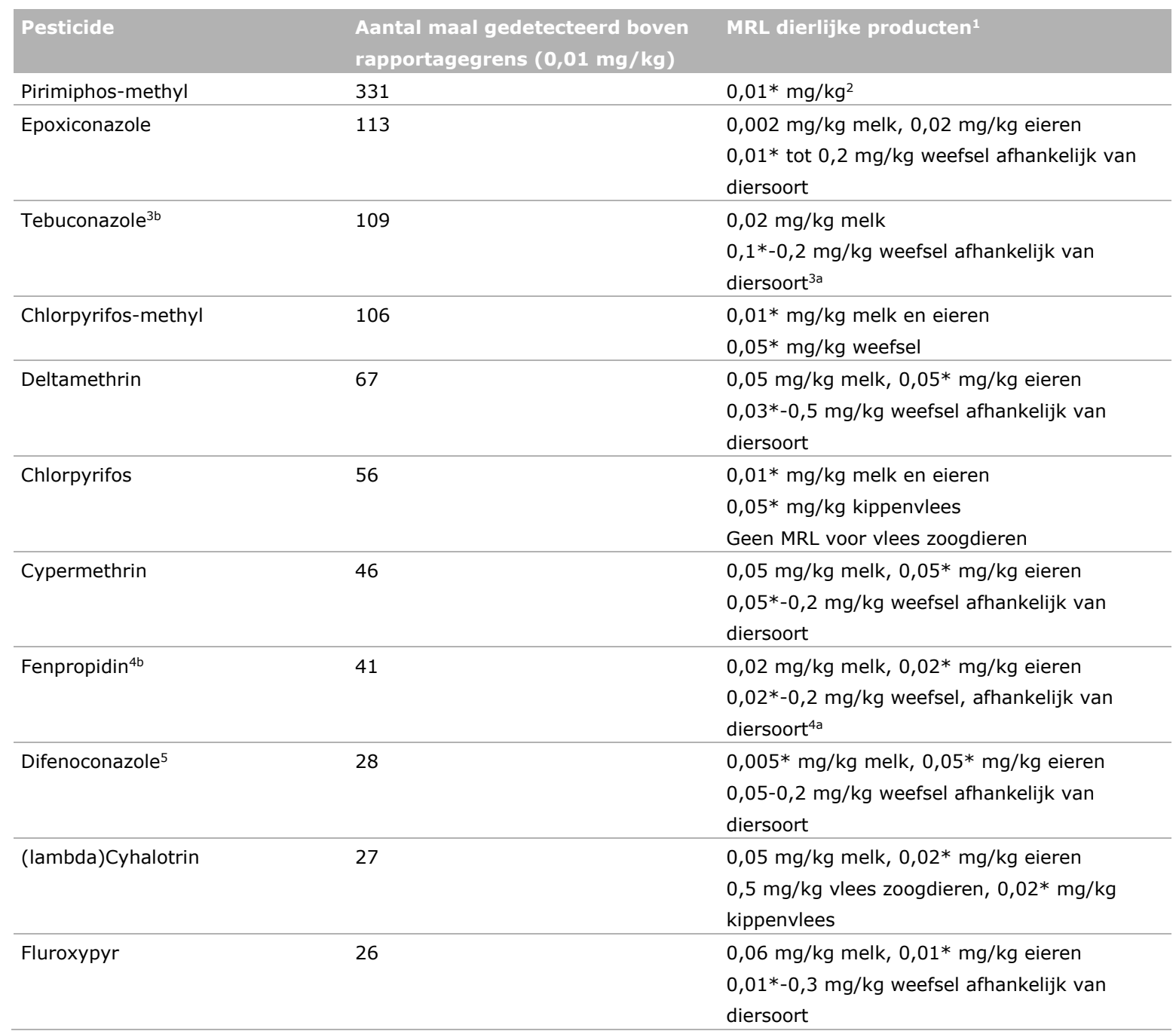

(1) Indien er een* achter de MRL staat betekent dit dat de MRL is vastgesteld op het laagste niveau dat nog betrouwbaar kan worden gemeten Indien er geen * is aangegeven, dan is uit studies gebleken dat dit pesticide teruggevonden kan worden in dierlijke producten (EU-MRL databank: http://ec.europa.eu/food/plant/pesticides/eu-pesticides-database/public/?event=activesubstance.selection\&language=EN).

(2) Hydroxypyrimidine metabolieten zijn (nog) niet opgenomen in de residudefinitie. Meer informatie betreffende de toxicologische relevantie is nodig. Dit wordt meegenomen bij de her-evaluatie van de MRL (voorzien voor januari 2018).

(3a) Som van tebuconazole, hydroxy-tebuconazole, en hun conjugaten, uitgedrukt als tebuconazole.

(3b) In dierlijke producten wordt alleen naar tebuconazole gekeken (meten van totale residue definitie vergt een afzonderlijke methode).

(4a) Som van fenpropidin, 2-methyl-2-[4-(2-methyl-3- piperidin-1-yl-propyl)-phenyl]propionic acid, en hun zouten, uitgedrukt als fenpropidin. Opmerking: de referentiestandaard van 2-methyl-2-[4-(2-methyl-3-piperidin-1-yl-propyl)-phenyl]propionic acid is niet commercieel verkrijgbaar.

(4b) In dierlijke producten wordt alleen naar fenpropidin gekeken. Door ontbreken van referentiestandaard kan het metaboliet niet bepaald worden.

(5) Difenoconazole zit niet in de scope van de methode voor dierlijke producten.

NB: uit dieroverdrachtstudies blijkt dat difenoconazole niet tot residuen $>0.01 \mathrm{mg} / \mathrm{kg}$ leidt [presentatie Lutz Alder, EURL meeting Freiburg 2010]. Het is onduidelijk waarom er dan toch MRL-toleranties vastgesteld zijn.

Voor de pesticiden genoemd in Tabel 11 zijn de MRL's voor dierlijke producten aangegeven. Met uitzondering van pririmiphos-methyl, chloorpyrifos-methyl en chloorpyrifos zijn er MRL's voor één of meer producten van dierlijke oorsprong vastgesteld, wat impliceert dat de stof gebruikt zou kunnen worden op gewassen die (ook) door dieren worden gegeten en overdracht van voer naar dierlijke producten kan optreden. Producten van dierlijke oorsprong worden, in vergelijking met groente, fruit en granen, maar zeer beperkt onderzocht op de aanwezigheid van residuen van pesticiden. Monitoring wordt vooral gedaan binnen monitoringsprogramma's van de overheid in het kader van Richtlijn 96/23/EG, en op veel beperktere schaal in het kader van Verordening (EG) 882/2004 (Verordening 
(EG) 396/2005). Bij monitoring in het kader van Richtlijn 96/23/EG ligt de nadruk op organochloorpesticiden, pyrethroïden en organofosforpesticiden/carbamaten. RIKILT onderzoekt jaarlijks circa 500 monsters vet (melkvet en vetweefsel) op de aanwezigheid van residuen van 20 organochloorpesticiden, circa 100 monsters vet (melkvet en vetweefsel) op 9 pyrethroïden en circa 260 monsters spier (vlees) en lever op organofosforpesticiden en carbamaten. Deze stoffen zijn sinds 2011 aangevuld met ongeveer 100 andere pesticiden (geprioriteerd in 2011). Alle frequent aangetroffen pesticiden in diervoeder (Tabel 11) worden ook in de dierlijke producten onderzocht, met uitzondering van difenoconazole. Hierbij moet opgemerkt worden dat voor tebuconazole en fenpropidin alleen de moederstof wordt geanalyseerd en niet de metabolieten, die waarschijnlijk relevanter zijn. Voor pirimiphos-methyl zijn geen metabolieten in de residu-definitie opgenomen, dat verandert mogelijk in de toekomst.

De afgelopen vijf jaar zijn er vrijwel geen pesticiden in dierlijke producten aangetoond, met uitzondering van de incidentele detectie van organochloorpesticiden en pyrethroïden. Er zijn geen MRL-overschrijdingen gevonden. Een aantal relevante metabolieten valt echter buiten de scope van de multi-residumethoden. Hetzelfde geldt voor pesticiden die niet met de multi-methoden kunnen worden gemeten, zogenaamde SRM-pesticiden, zoals chloormequat, paraquat, diquat. Deze zijn niet opgenomen in de reguliere monitoringsprogramma's. De RASFF-databank vermeldt slechts enkele meldingen van pesticiden in dierlijke producten in de periode 2011-2016; het betrof cyromazine en abamectine. Ook hierbij geldt dat binnen de EU de scope van de methoden voor pesticiden in dierlijke producten hoofzakelijk gericht is op stoffen vermeld in Richtlijn 96/23/EG. De beschikbare residudata voor diervoeder en dierlijke producten geven aan dat de kans op MRL-overschrijdingen klein is. Voor organochloorpesticiden en in mindere mate voor pyrethroïden zijn veel gegevens beschikbaar en kan een goed beeld worden verkregen van de situatie. Voor de overige pesticiden, inclusief die stoffen waar overdracht kan optreden, is dit beeld incompleet omdat niet alle stoffen in dierlijke producten geanalyseerd worden of kunnen worden (ontbreken referentiestandaarden voor relevante metabolieten).

Voor SRM-pesticiden die aparte analytische methoden vereisen, geldt dat zowel voor diervoeder als voor dierlijke producten nauwelijks residudata beschikbaar zijn. De aanwezigheid van deze stoffen in de keten is echter in 2015-2016 bevestigd; glyfosaat en paraquat zijn onder andere aangetroffen in sojaproducten. Op basis van deze bevindingen heeft de NVWA besloten de controle op paraquat in soja per 1 april 2017 verder te verscherpen. De aanbeveling van EFSA is om monitoring van pesticiden residuen uit te voeren in diervoeder in plaats van in dierlijke producten, om hiermee informatie te genereren voor de dierlijke blootstelling, mogelijke overdracht naar dierlijke producten, en de relevantie voor de humane blootstelling (EFSA, 2016a).

Voor veel diervoeder(grondstoffen)/stof combinaties zijn geen MRL's vastgesteld. Daarnaast is er sprake van hiaten in de huidige monitoringsprogramma's. Voor diervoeder- en ingrediënten betreft dit met name stoffen die buiten de scope van de multiresidumethoden vallen. De detectie in 2016 van het in de EU verboden pesticide paraquat in sojaproducten in gehalten boven de MRL is hiervan een voorbeeld. Mogelijk speelde dit al voor 2016. Voor dierlijke producten geldt in bredere zin dat er hiaten zitten in de huidige monitoringsprogramma's waarbij met name meer aandacht nodig is voor relevante metabolieten uit de residudefinitie. Momenteel wordt vanuit de EC de druk op de agrochemische industrie opgevoerd om analytische referentiestandaarden van metabolieten beschikbaar te krijgen om controle mogelijk te maken. Dit kan leiden tot detectie van residuen die tot dusver buiten de scope van de methoden vielen. Opgemerkt dient te worden dat de MRL's van een aantal pesticiden in dierlijke producten de afgelopen jaren verlaagd zijn naar niveaus lager dan de default LOQ van $0,01 \mathrm{mg} / \mathrm{kg}$. Verlaging van MRL's, hetzij op basis van toxiciteit, hetzij vanwege intrekking in de $\mathrm{EU}$, zou kunnen leiden tot meer frequente MRL-overschrijdingen in de toekomst. Voor pesticiden met een lage MRL in dierlijke producten is het relevant deze op te nemen in de monitoring van diervoeder.

\section{a. Primaire plantaardige productie}

Pesticiden worden in vrijwel alle akker- en tuinbouwteelten toegepast, met uitzondering van de biologische teelt (alhoewel onder bepaalde voorwaarden gewasbeschermingsmiddelen ook in de biologische teelt mogen worden toegepast volgens de Europese Eco-standaard). Residuen kunnen in alle diervoeders en -grondstoffen voorkomen. Welke pesticiden het betreft en welke residugehalten 
nog in plantaardige grondstoffen kunnen worden aangetroffen, verschilt sterk per grondstof, land van herkomst en in de tijd. In de teelt van herbicide-resistente GGO gewassen worden herbiciden als glyfosaat en glufosinaat regelmatig gebruik om onkruiden te doden. Deze gewassen zullen anders dan niet-GGO gewassen dan ook vaker residuen bevatten van deze herbiciden.

b. Invoer, import en verwerking plantaardige producten niet voedergewassen, $1^{\mathrm{e}}$ fase Pesticiden die geen toelating hebben binnen de EU kunnen via import van grondstoffen uit derde landen in diervoeder terecht komen. Soja is hiervan het bekendste voorbeeld.

c. Verwerking plantaardige producten, $2^{\mathrm{e}}$ fase

Bij de verwerking van plantaardige producten tot levensmiddelen (bijv. olie uit oliehoudende zaden) ontstaan bijproducten die vaak als diervoedergrondstof worden gebruikt. Stro is een voorbeeld van een bijproduct van de graanteelt dat als bodembedekking en voer wordt gebruikt (Mol et al., 2014). Afhankelijk van de eigenschappen van het pesticide kunnen de concentraties in de bijproducten hoger zijn dan in het totale gewas of graan. Dit verschilt sterk per pesticide en type bijproduct. Een voorbeeld hiervan is de aanwezigheid van paraquat in sojabonen dat buiten de EU gebruikt mag worden. Paraquat lost niet op in de sojaolie en blijft na scheiding aanwezig in de bijproducten (sojaschroot). Afhankelijk van de oplosbaarheid van een pesticide in olie of water, hopen pesticiden na scheiding op in een van beide fracties.

d. Verwerking plantaardige reststromen (voormalig levensmiddelen)

Levensmiddelen kunnen residuen bevatten van pesticiden. Voor de grondstoffen van levensmiddelen is doorgaans een goede MRL-controle, de verwachting is dat dit niet tot problemen in diervoeders leidt, tenzij reststromen zodanig bewerkt worden of in geconcentreerde vorm als diervoeder worden gebruikt dat er sprake is van een verhoging van de gehalten.

e. Verwerking dierlijke producten, $1^{\mathrm{e}}$ en $2^{\mathrm{e}}$ fase

Dierlijke producten kunnen pesticiden bevatten, het gaat hierbij met name om organochloorverbindingen. Voor organochloorverbindingen zijn MRL's in diervoeders vastgesteld (Richtlijn 2002/32/EG). Zolang hieraan voldaan wordt zijn er geen gevaren te verwachten; dit is echter niet altijd het geval (Adamse et al., 2014).

f. Verwerking bijproducten tot voedermiddelen

Bij de verwerking van visproducten tot diervoeder kan het bijproducten hiervan organochloorpesticiden bevatten (zie verder onder e.).

g. Chemische productie additieven

Het is onbekend of pesticiden worden gebruikt bij de productie van additieven, maar dit lijkt onwaarschijnlijk.

\section{h. Productie mengvoeder}

Naar verwachting ontstaan er geen extra gevaren door het mengen van ingrediënten, verpakken en bewaren van mengvoeders. Eventuele sterk met pesticiden vervuilde ingrediënten kunnen verdund worden door het mengen met niet besmette ingrediënten.

\subsubsection{Overdracht naar dierlijke producten}

Met het diervoeder kunnen landbouwhuisdieren pesticiden binnen krijgen. Deze worden, al dan niet gemetaboliseerd, verdeeld over de diverse organen en weefsels en uitgescheiden via urine, feces, melk en eieren. Het is sterk stofafhankelijk of en in welke mate residuen in voer leiden tot residuen in dierlijke producten zoals melk, eieren, vet en (orgaan)vlees. Er is met name informatie beschikbaar over persistente lipofiele pesticiden (de organochloorpesticiden, zoals DDT, dieldrin, $\mathrm{HCH}$ etc.) die accumuleren in melk, eieren en vet, en in mindere mate over pesticiden zoals organofosforpesticiden en pyrethroïden (Kan and Meijer, 2007; Pulina et al., 2014). Voor bepaalde pesticiden worden dieroverdrachtstudies gedaan. Dit is het geval indien: i) residuen $>0,1 \mathrm{mg} / \mathrm{kg} \mathrm{dw}$ aanwezig kunnen zijn op gewassen die als diervoeder gebruikt worden, ii) uit metabolisme studies blijkt dat significante residuen $(>0,01 \mathrm{mg} / \mathrm{kg}$ ) kunnen voorkomen in eetbare dierlijke producten, iii) uit metabolisme studies blijkt dat bioaccumulatie kan optreden (EC MRL guidelines livestock feeding studies appendix G). 
Wanneer dieroverdrachtstudies uitgevoerd zijn, zijn de resultaten opgenomen in het registratiedossier (niet voor het publiek toegankelijk) en deels ook in Draft Assessment Reports (DARs) van EFSA (wel openbaar). Deze studies zijn ook de basis voor het vaststellen van MRL's voor producten van dierlijke oorsprong.

\subsubsection{Regulering}

Specifiek voor diervoeder(ingrediënten) zijn alleen een aantal organochloorpesticiden gereguleerd als ongewenste stof (Richtlijn 2002/32/EG). Voor de overige pesticiden zijn MRL's vastgesteld voor de primaire agrarische producten, waarbij geen onderscheid gemaakt wordt tussen producten voor humane voeding of diervoeder (Verordening (EG) 396/2005. Voor producten die alleen als diervoeder worden gebruikt (zoals gras, luzerne, snijmaïs, voederbieten), evenals afgeleide producten (zoals hooi en stro) zijn tot nu toe geen MRL's vastgesteld en is geen handhaving aan de hand van MRL's mogelijk.

Naast regulering van pesticiden residuen in een deel van de diervoedergrondstoffen is er ook regulering in de keten via MRL's van pesticiden in de eetbare dierlijke producten. MRL's voor dierlijke producten zijn afgeleid uit dieroverdrachtstudies die (indien noodzakelijk, zie eerder) tijdens het registratietraject van de pesticide zijn uitgevoerd. Indien overdracht optreedt, wordt een MRL vastgesteld.

Er zijn 137 pesticiden in de EU met een MRL in producten van één of meerdere landbouwhuisdieren (koemelk, kippeneieren, en vlees, lever en nier van runderen, varkens, schapen en kippen). Dit aantal is inclusief een aantal inmiddels niet meer toegelaten, persistente pesticiden die als milieucontaminant in de diervoederketen terecht kunnen komen. Indien er geen gebruik is op voedergewassen of er geen residuen $(<0,1 \mathrm{mg} / \mathrm{kg}$ ) op gewassen zijn geconstateerd die gebruikt worden als diervoeder, of er geen overdracht plaats vindt, is de MRL gelijk gesteld van de bepalingsgrens (Limit Of Quantification (LOQ)) zoals vastgesteld tijdens de beoordeling van het registratiedossier. Deze ligt meestal op 0,01 of $0,05 \mathrm{mg} / \mathrm{kg}$ en is in de EU-MRL databank te herkennen aan de asterisk (EU-Pesticides database). Voor enkele actieve stoffen van bestrijdingsmiddelen geldt dat deze ook als actieve stof in diergeneesmiddelen worden gebruikt. De MRL's voor residuen van deze stoffen staan vermeld in de bijlage van Verordening (EU) 37/2010.

MRL's voor residuen van actieve stoffen van gewasbeschermingsmiddelen op gewassen zijn gebaseerd op GAP (goede agrarische praktijk) en zijn in de meeste gevallen geen toxicologische grenswaarden. MRL-overschrijdingen in diervoeder(-grondstoffen) of in producten van dierlijke oorsprong betekenen dus niet automatisch een gezondheidsrisico voor het dier of consument. MRL-overschrijdingen duiden echter wel op strijdigheid met GAP en een onnodig hogere blootstelling van dier of consument aan pesticiden.

\subsubsection{Conclusie}

Er worden wel norm overschrijdingen gevonden voor pesticiden in diervoeders, maar pesticiden worden weinig aangetroffen in dierlijke producten en vormen geen gevaar voor de volksgezondheid via de diervoeder route. Pesticiden worden daarom ook niet opgenomen op de short-list voor diervoeder.

\subsubsection{Minerale Oliën}

\subsubsection{Algemeen}

Minerale olie is een algemene naam voor minerale olie koolwaterstoffen ( $\mathrm{MOH})$. $\mathrm{MOH}$ zijn voornamelijk afkomstig uit ruwe olie, maar kunnen ook uit bijvoorbeeld gas en kolen verkregen worden. De exacte samenstelling hangt af van de oorsprong en de manier van verwerking van de ruwe olie. $\mathrm{MOH}$ mengsels bevatten alifatische koolwaterstoffen, zowel lineaire als vertakte ketens ("paraffine"). Ketenlengten variëren in het algemeen van C10 tot C50 (EFSA, 2012). Verzadigde koolwaterstoffen staan bekend als "Mineral Oil Saturated Hydrocarbons" (MOSH). Minerale olie kan ook een grote verscheidenheid aan cyclische koolwaterstoffen bevatten zoals naftenen en aromaten. Deze laatste groep staat ook bekend als "Mineral Oil Aromatic Hydrocarbons" (MOAH) (Bruhl 2016). Binnen deze klassen zijn er enorme aantallen van de afzonderlijke componenten (EFSA, 2012). Minerale olie kan op verschillende wijzen in de voedselketen terecht komen. Minerale olie is toegestaan als hulpmiddel bij de gewasbescherming van pootgoed aardappelen, bloembollen, appels, peren en pruimen (CTGB 2017). MOH worden toegepast in drukinkten en kunnen na toepassing door 
de verpakking migreren in het eindproduct. Zoals vermeld bij de ketenbeschrijving (3.1.2), wordt er een actiegrens gehanteerd van $0.15 \% \mathrm{w} / \mathrm{w}$ voor de aanwezigheid van verpakkingsmaterialen (NVWA, 2015). Dit kan betekenen dat diervoeder gecontamineerd wordt met minerale oliën via het verpakkingsmateriaal. Het is voor diervoeder niet bekend óf en in welke mate migratie van $\mathrm{MOH}$ uit verpakking in het voer ook daadwerkelijk voorkomt. Ook is de relatieve bijdrage van verschillende routes voor aanwezigheid van $\mathrm{MOH}$ in diervoeder onbekend.

\subsubsection{Aanwezigheid minerale olie in sub-ketens}

$\mathrm{Er}$ is beperkte informatie over het voorkomen van $\mathrm{MOH}$ in diervoeders. Mediane MOSH-gehalten gebaseerd op 141 monsters van voedervet, diervoeder voor pluimvee en niet-gespecificeerde voeders waren, respectievelijk, 20, 80 en 25 mg/kg (P95 concentraties van, respectievelijk, 1800, 400 en $80 \mathrm{mg} / \mathrm{kg}$ ) (EFSA, 2012). In het NP Diervoeder wordt sinds $2013 \mathrm{MOH}$ gemonitord in een reeks van dierlijke vetten, plantaardige oliën en destillaten. In 2013, 2014, 2015 zijn - respectievelijk - 36, 14 en 14 monsters gecontroleerd met mediane waarden van - respectievelijk - 176, 93 en $115 \mathrm{mg} / \mathrm{kg}$ (maximale concentraties van - respectievelijk - 5570, 360 en $280 \mathrm{mg} / \mathrm{kg}$ ) (niet gepubliceerde resultaten). In 2013, heeft dit geleid tot een RASFF-melding ( $5570 \mathrm{mg} / \mathrm{kg}$ minerale olie in kippenvet voor petfood). In de overige jaren werd geen overschrijding van de GMp-norm gevonden.

\section{a. Primaire plantaardige productie}

Besmetting van primaire plantaardige producten kan voorkomen. Fediol (Europese federatie van plantaardige oliën en eiwitten industrie) heeft een code of practice opgesteld (Fediol., 2016) met betrekking tot minerale olie. Besmetting kan optreden door het gebruik van minerale olieproducten (o.a. smeermiddelen) in machines en onderdelen die met de producten in aanraking komen. Ook lekkage van diesel kan tot besmetting leiden. Ook opslag kan leiden tot besmetting, onder andere door migratie van drukinkten uit verpakkingen in verpakte bonen en zaden. Ook kan minerale olie gebruikt worden als anti-stofmiddel bij overslag van producten (Fediol., 2016). De mate waarin besmetting optreedt in elk van deze stappen is niet bekend. Minerale olie is ook toegestaan als hulpmiddel in de gewasbescherming bij een aantal gewassen (zie 3.2.8.1)

b. Invoer, import en verwerking plantaardige producten niet voedergewassen, $1^{\mathrm{e}}$ fase In 2008 werd in Oekraïne een partij zonnebloemolie ontdekt die, via fraude, verontreinigd was met minerale olie (RASFF, diverse meldingen in food). Daarna zijn diverse partijen plantaardige olie met voeding als bestemming gemeld via RASFF. Het betrof hier weliswaar meldingen voor humane voeding, maar het is aannemelijk dat ook plantaardige olie voor diervoeder besmet kan zijn met minerale olie. Minerale olie kan gebruikt worden als anti-stofmiddel en kan zich concentreren in deodestillaten (Fediol., 2016). Tevens kan besmetting optreden vanuit smeermiddelen.

c. Verwerking plantaardige producten, $2^{\mathrm{e}}$ fase

Bij de verwerking van plantaardige producten kan besmetting optreden tijdens processing, zoals besmetting van condensaten van fysische raffinage van plantaardige oliën of andere reststromen (Brühl, 2016; EFSA, 2012).

d. Verwerking plantaardige reststromen (voormalig levensmiddelen)

Plantaardige retourstromen kunnen gecontamineerd zijn. De besmetting kan afkomstig zijn vanuit drukinkten die vanuit verpakkingen in de voedingsmiddelen migreren. Wanneer deze

voedingsmiddelen via retourstromen in de diervoederketen terechtkomen, kan dat bijdragen aan de besmetting van diervoeder met minerale olie.

e. Verwerking dierlijke producten, $1^{\mathrm{e}}$ en $2^{\mathrm{e}}$ fase

Het is niet bekend in welke mate besmetting plaatsvindt bij de verwerking van dierlijke producten.

f. Verwerking bijproducten tot voedermiddelen

Bij de verwaarding van gebruikte oliën en vetten kan via frauduleus handelen minerale olie in de reststromen terecht komen. De mate waarin dat gebeurt is niet bekend.

g. Chemische productie additieven

Er zijn geen gevallen bekend van de besmetting van additieven. 
h. Productie mengvoeder

Bij de productie van mengvoeder kan besmetting optreden vanuit de ingrediënten, of door besmetting met minerale olie houdende smeermiddelen.

\subsubsection{Overdracht naar dierlijke producten}

Minerale olie kan overgedragen worden naar dierlijke producten. Indicatieve resultaten in kippen die gecontamineerd diervoeder kregen, lieten een overdracht van 1,5 tot 3\% naar de eieren zien (Grob et al., 2001). Ook van koeien en geiten is bekend dat minerale oliën worden opgenomen en dus aanwezig kunnen zijn in melk en vlees van deze dieren. De mate van overdracht is echter niet bekend (Bulder et al., 2008).

\subsubsection{Regulering}

Voor het maximale gehalte aan minerale olie in diervoeders of -grondstoffen is geen EU of Nederlandse norm vastgesteld. GMP+ hanteert een norm van $400 \mathrm{mg} / \mathrm{kg}$ voor oliën en vetten (NVWA, 2015). Er is een enkele RASFF-melding ingediend in 2013, betreffende een gehalte van $5570 \mathrm{mg} / \mathrm{kg}$ $\mathrm{MOH}$ in vet van gevogelte uit Frankrijk dat bestemd was voor petfood.

\subsubsection{Conclusie}

Minerale oliën kunnen in diervoeder terechtkomen via het gebruik van smeermiddelen in bv. plantaardige productie en mogelijk ook via (restanten van) verpakkingsmaterialen. Er zijn geen wettelijke limieten voor minerale oliën, maar er is wel een GMP+-norm. Er zijn enkele overschrijdingen gevonden voor minerale oliën in diervoeder. Er is echter weinig bekend over de overdracht naar dierlijke producten. Ook is er nog onvoldoende bekend over de gehalten aan m.n. MOAH in diervoeders. Er is daarom meer informatie nodig om minerale oliën te kunnen prioriteren.

\subsubsection{Procescontaminanten}

\subsubsection{Algemeen}

Procescontaminanten zijn contaminanten die tijdens het productieproces ontstaan en zo in diervoeder terecht kunnen komen. Procescontaminanten kunnen ontstaan wanneer producten worden behandeld om de verwerkbaarheid, smaak en/of houdbaarheid te verbeteren. Procescontaminanten kunnen ontstaan door verschillende vormen van behandeling, maar in dit onderdeel worden uitsluitend die contaminanten genoemd die onder invloed van een hittebehandeling gevormd worden, omdat deze relevant zijn voor de productie van diervoeder.

$\mathrm{Er}$ is de laatste jaren is steeds meer aandacht gekomen voor hitte geïnduceerde procescontaminanten (heat induced process contaminants (HIPC)). HIPC's ontstaan bij het verwarmen van voedsel, waarbij hitte toegepast wordt om de kwaliteit en smaak te verbeteren (bijvoorbeeld het roosteren van koffie), het product beter verwerkbaar te maken (bijvoorbeeld deodorisatie door destillatie), en/of het conserveren van het product (bijvoorbeeld pasteuriseren en steriliseren van zuivelproducten). Voorbeelden van HIPC's zijn acrylamide, (esters van) 2- en 3-monochloorpropaandiol (2-MCPD en 3-MCPD) glycidyl vetzuuresters (GE), 5-hydroxymethylfurfural (HMF), furan, fructoselysine en carboxymethyllysine.

2- en 3-MPCD esters worden gegenereerd uit monoglyceriden en diglyceriden in de aanwezigheid van chloor. Vorming van deze stoffen gebeurt tijdens de raffinage van plantaardige olie met name in de deodorisatiestap. In deze processingstap wordt de olie gedurende tientallen minuten (tot soms 1-2 uur) bij hoge temperaturen $\left(>200^{\circ} \mathrm{C}\right)$ verhit. Ook glycidolesters (GE) worden gegenereerd tijdens de deodorisatie van plantaardige olie. Van met name palmolie is bekend dat deze contaminanten gevormd worden tijdens de verhitting, maar ook bij andere plantaardige oliën komt de vorming voor (EFSA, 2016). De volgende factoren zijn belangrijk voor de vorming van 2-, 3- MCPD esters en GE:

- De aanwezigheid van chloor in de grondstof of tijdens het verwerken;

- De mate waarin diglyceriden en monoglyceriden voorkomen in de grondstof of product als gevolg van (enzymatische) afsplitsing van vrije vetzuren van triglyceriden;

- Temperatuur: een hogere temperatuur geeft hogere gehalten;

- Tijdsduur: een langere tijdsduur bij verhoogde temperatuur zorgt voor hogere gehalten;

- Zuur: de aanwezigheid van zuur tijdens processing kan leiden tot hogere gehalten. 
Acrylamide en HMF worden gegenereerd in een Maillardreactie van reducerende suikers en aminozuren, in het bijzonder asparagine, onder hoge temperaturen $\left(>120^{\circ}\right.$ ), met name in zetmeelrijke producten en ingrediënten en onder lage vochtigheid condities. Andere factoren die daarbij een rol spelen zijn tijdsduur en temperatuur van de hittebehandeling en de concentraties van het aminozuur asparagine. Asparagine is aanwezig in veel diervoeder ingrediënten (Li et al., 2011).

$\mathrm{Er}$ is weinig bekend over het voorkomen van deze HIPC's in diervoeder. Recente EFSA opinies geven alleen informatie over HIPC's in voedsel, maar niet in diervoeder (EFSA, 2016b). In de wetenschappelijke literatuur is geen informatie over het voorkomen in diervoeder gevonden. 2-, 3-MCPD-esters en GE kunnen in vetzuurdestillaten voorkomen, afhankelijk van de gebruikte deodorisatie condities (persoonlijke mededeling Florence Lacoste, Iterg). HIPC's maken geen onderdeel uit van het Nationaal Plan Diervoeders, en er zijn, voor zover bekend, geen surveys gedaan in Nederland naar het voorkomen van HIPC's in diervoeder. Er zijn geen limieten gesteld voor de aanwezigheid van deze contaminanten in diervoeder. Het voorkomen van deze contaminanten in diervoeder is echter niet uit te sluiten (van Rooijen et al., 2014). Bijvoorbeeld bij het gebruik van retourstromen vanuit de supermarkt in varkensvoeding.

In bijen wordt "high fructose corn syrup" (HFCS) gebruikt als een suikerbron voor bijen tijdens de overwintering. HFCS kan HMF bevatten en gehalten boven $150 \mathrm{mg} / \mathrm{kg}$ zijn giftig voor bijen (van der Steen, 2014).

\subsubsection{Aanwezigheid procescontaminanten in sub-ketens}

RASFF bevat acht meldingen voor HMF in diervoeder in de periode van 2005 tot 2015. Het betrof hier meldingen met betrekking tot aanvullend diervoeder voor honingbijen. Er zijn geen meldingen voor de overige procescontaminanten.

a. Primaire plantaardige productie

Er is geen reden om aan te nemen dan 2-, 3-MCPD en GE ontstaan in de primaire plantaardige productie. Hetzelfde geldt voor acrylamide.

b. Invoer, import en verwerking plantaardige producten niet voedergewassen, $1^{\mathrm{e}}$ fase Het is mogelijk dat procescontaminanten in deze groep producten voorkomen, mits deze producten een hittebehandeling hebben ondergaan tijdens processing. Hier is geen informatie over gevonden in relatie tot de productie van diervoeder.

c. Verwerking plantaardige producten, $2^{\mathrm{e}}$ fase

2-, 3-MCPD esters en GE kunnen voorkomen in lage gehalten in ruwe plantaardige olie, als gevolg van condities tijdens de primaire productie. Tijdens processing waarbij de ruwe olie geraffineerd wordt kunnen gehalten aanzienlijk toenemen, afhankelijk van de procescondities. De mate waarin deze contaminanten daadwerkelijk in diervoeder ingrediënten voorkomen is onbekend. Hetzelfde geldt voor acrylamide.

d. Verwerking plantaardige reststromen (voormalig levensmiddelen)

Omdat 2,-3-MCPD esters en GE kunnen voorkomen in voedingsmiddelen is het aannemelijk dat reststromen bijdragen aan de besmetting in de diervoederketen. De mate waarin is niet bekend.

e. Verwerking dierlijke producten, $1^{\mathrm{e}}$ en $2^{\mathrm{e}}$ fase

Het is onbekend in welke mate proces contaminanten voorkomen in dierlijke (bij)producten die gebruikt kunnen worden als diervoeder.

f. Verwerking bijproducten tot voedermiddelen Vetzuurdestillaten zijn een bijproductenproduct van de raffinage van plantaardige oliën. Tijdens dit raffinageproces kunnen 2,-3-MCPD esters en GE ontstaan. Deze contaminanten kunnen, afhankelijk van de procescondities, in de destillaten voorkomen of achter blijven in de geraffineerde olie. Het is echter niet bekend of deze contaminanten ook voorkomen in de destillaten die in de diervoederketen terecht komen. 
g. Chemische productie additieven

Hier is niets over bekend in relatie tot procescontaminanten.

h. Productie mengvoeder

Hittebehandeling tijdens de productie van mengvoeder kan leiden tot het ontstaan van procescontaminanten. Er is geen informatie over het voorkomen van 2,-3-MCPD esters en GE in diervoeder, evenmin over het voorkomen in de vrije vorm. In een studie van Pabst et al. (2005) zijn drie monsters commercieel mengvoederpellets geanalyseerd op acrylamide en die bevatten 180, 145 en $140 \mu \mathrm{g} / \mathrm{kg}$. De acrylamide was mogelijk afkomstig van de bestanddelen van de voederpellets (Pabst et al., 2005).

\subsubsection{Overdracht naar dierlijke producten}

Gebaseerd op een beperkt aantal toxicokinetische studies is vastgesteld dat het vrije 3-MCPD en glycidol snel worden uitgescheiden na toediening. De aan-ester-gebonden vormen worden langzamer uitgescheiden. Dit komt omdat het ester moet worden afgesplitst door middel van hydrolyse in het maag-darm kanaal voordat de vrije vorm beschikbaar is voor opname en excretie (EFSA, 2016b). Snelle uitscheiding kan erop wijzen dat ophoping van 3-MCPD esters en GE in dierlijk weefsel beperkt is, hoewel hierover geen informatie beschikbaar is. Het is onbekend of 2- en 3-MCPD en GE kunnen worden overgedragen naar andere dierlijke producten zoals melk en eieren.

In een overdrachtsexperiment met acrylamide werd melkvee gevoerd met 1,5 g acrylamide per koe per dag, wat resulteerde in een overdracht naar melk van circa 0,24\% (170 $\mu \mathrm{g} / \mathrm{l})$ (Pabst et al., 2005). Uitgaande van de gemeten commerciële voeders in deze studie zou een gehalte van $0,2 \mu \mathrm{g} / \mathrm{l}$ melk verwacht kunnen worden. In een overdrachtsexperiment met leghennen die gedurende vier weken gevoerd werden met acrylamide besmet voer (op basis van commerciële ingrediënten, met een gehalte van $671 \mu \mathrm{g}$ acrylamide/kg voer) bedroeg de overdracht naar eieren $1 \%$. In de groep kippen gevoerd met voer met een lagere concentratie acrylamide (125 $\mu \mathrm{g}$ acrylamide/kg voer) werd een overdracht van $2 \%$ geconstateerd. De acrylamidegehalten in de eieren van de hoogst gedoseerde groep namen in vier weken toe van $7,9 \mu \mathrm{g} / \mathrm{kg}$ ei tot een concentratie van $17 \mu \mathrm{g} / \mathrm{kg}$. Behalve in de eieren werd acrylamide ook gevonden in de organen van de kippen: in de lever $(9,9 \mu \mathrm{g} / \mathrm{kg})$, borstspierweefsel $(16,6 \mu \mathrm{g} / \mathrm{kg})$ en in de nieren $(27,7 \mu \mathrm{g} / \mathrm{kg}$ ) (Halle et al., 2006).

\subsubsection{Regulering}

Er zijn geen maximumlimieten vastgesteld voor procescontaminanten in diervoeder.

\subsubsection{Conclusie}

Er zijn enkele RASFF-meldingen voor procescontaminanten (m.n. HMF in diervoeder voor bijen). Er zijn echter geen wettelijke limieten en er zijn dan ook weinig data over het voorkomen van procescontaminanten in diervoeder. Er zijn wel gegevens over overdracht van acrylamide naar dierlijke producten, maar weinig tot geen gegevens voor de overige procescontaminanten. Er zijn dus meer gegevens nodig om procescontaminanten te kunnen prioriteren.

\subsubsection{Overige gevaren}

In deze sectie worden een aantal overige chemische gevaren benoemd, waarvoor minder informatie beschikbaar is dan de tot nu toe benoemde gevaren. Informatie over het optreden in de subketens is zo summier, dat de sub-ketens niet apart worden benoemd.

\subsubsection{Polycyclysche aromatische koolwaterstoffen}

Polycyclische aromatische koolwaterstoffen (PAK's) zijn een groep chemicaliën die kunnen ontstaan door onvolledige verbranding of pyrolyse van organisch materiaal. Benzo[a]pyreen wordt vaak gezien als marker voor de groep PAK's, evenals de som van benzo[a]pyreen, chryseen, benz[a]anthraceen en benzo[b]fluorantheen (PAK4). PAK's kunnen via vetten en vetzuren in diervoeder terechtkomen, maar kunnen ook ontstaan tijdens de productie van diervoeder, bijvoorbeeld wanneer gras kunstmatig gedroogd wordt tot graspellets (Bulder et al., 2006; Kan et al., 2003). In 2004 was er een RASFFmelding betreffende PAK's in graspellets. Overige RASFF-meldingen betroffen levensmiddelen, waarbij PAK's met name werden aangetroffen in oliën van gerookte vis en plantaardige oliën. Er zijn geen wettelijke limieten voor PAK's in diervoeder en daarom zijn er ook weinig gegevens van PAK's in 
diervoeder. Door het RIKILT worden PAK's soms in grasmonsters geanalyseerd na een milieubrand. Dierexperimenten laten zien dat PAK's gemetaboliseerd worden in koeien, waardoor de uiteindelijke concentraties PAK's in melk laag zijn (Kan et al., 2003). Wel worden de metabolieten teruggevonden in melk. De toxicologische eigenschappen van deze metabolieten zijn echter grotendeels onbekend (Bulder et al., 2006).

\subsubsection{Hormonen}

In het NP diervoeder worden hormonen niet geanalyseerd, maar ze worden wel geanalyseerd in monsters van dier(lijke) producten (bijvoorbeeld niervet of urine) in het kader van het Nationaal Plan Residuen. In 2002 is er een incident geweest met medroxy progesteron acetaat (MPA) in varkens. Dit kwam aan het licht doordat de Diergeneeskunde Faculteit van de Universiteit Utrecht onderzoek deed aan zeugen die niet drachtig werden. Nader onderzoek wees uit dat een reststroom (melassestroop) van farmaceutische bedrijven gebruikt was als ingrediënt in de diervoedersector. Deze melassestroop werd als coatingsmateriaal voor anticonceptiepillen gebruikt en bevatte daardoor MPA. Sinds dit incident is MPA niet meer aangetroffen in melassestroop. Een aan MPA verwante stof, MLA, mag in de Verenigde Staten gebruikt worden als diervoederadditief. In theorie zouden hormonen die buiten de EU zijn toegestaan en via diervoeder worden toegediend door import ook in de EU terecht kunnen komen. Het gebruik van melk of delen van melk in diervoeding kan ook leiden tot verhoogde blootstelling van dieren aan hormonen.

Visvoer kan verhoogde concentraties oestradiol bevatten, indien hierin kuit is verwerkt. Aangezien het hier gaat om een van nature aanwezig hormoon is er een actiegrens opgesteld voor de aanwezigheid van oestradiol in visvoer van $100 \mu \mathrm{g} / \mathrm{kg}$.

Voor een andere groep van verboden stoffen, de $\beta$-agonisten zoals clenbuterol, is toediening via het voer een gebruikelijke route. De problematiek met deze groep van stoffen kwam aan het licht doordat bleek dat bepaalde oraal toe te dienen diergeneesmiddelen ter bestrijding van luchtwegaandoeningen bewust in hogere dosering werden toegediend, in verband met hun groeibevorderende werking. Vervolgens bleek dat ook een aantal nauw verwante verbindingen aan diervoeders werden toegediend via, bijvoorbeeld, vitamine- of mineralenmengsels. Op dit moment vindt breed onderzoek op residuen van $\beta$-agonisten plaats in een veelheid aan materialen, waaronder ogen (retina) en haren.

\subsubsection{Genetisch Gemodificeerde Organismen (GGO)}

Bijna alle diervoeder bevat in meer of mindere mate grondstoffen afkomstig van GGO. De NVWA richt zich daarom met name op de controle van juiste etikettering van GGO-bevattende diervoeders, en op de detectie van niet-toegelaten GGO's (NVWA, 2017b). Bij een correcte etikettering bevat een voedermiddel dat niet geëtiketteerd is als GGO bevattend maximaal 0,9\% van een in de EU toegelaten GGO. Een complicerende factor is dat verontreinigingen met andere voedermiddelen niet vermeld hoeven te worden op het etiket wanneer het percentage verontreiniging lager is dan 5\% (Verordening (EG) 767/2009. Een batch maïs zou volgens deze wetgeving dan meer dan 0,9\%, maar minder dan 5\% GGO-soja kunnen bevatten zonder dat dit geëtiketteerd hoeft te worden (Laurensse et al., 2010). Niet in de EU toegelaten GGO mogen niet als diervoeder worden gebruikt. Hiervoor geldt een nultolerantie. Veel additieven, zoals vitaminen en enzymen, worden geproduceerd met behulp van gemodificeerde organismen. Restanten van deze GGO organismen kunnen achterblijven in de additieven (FEFAC annual report 2014-2015). Bij de productie van diervoeders treedt daarnaast versleping op tussen de verschillende partijen diervoerder; dit is de oorzaak dat in bijna alle diervoeders GGO worden teruggevonden.

In Nederland worden jaarlijks ca. 200 diervoedermonsters geanalyseerd op de aanwezigheid van GGO's. Recentelijk is een overzicht gemaakt van de resultaten van deze analyses in de periode 20102014 (Adamse et al., 2016). In totaal zijn in deze vijf jaren meer dan 1000 monsters van verschillende diervoeders en ingrediënten geanalyseerd; de meerderheid van deze monsters was genomen van oliezaden (met name soja) en oliezaad producten, mengvoer en granen (met name maïs). In bijna alle monsters zijn GGO elementen aangetroffen. In deze periode zijn twee niettoegelaten GGO gevonden, één in maïs en één in rijst. Dit aantal is laag ten opzichte van het aantal meldingen in deze periode in RASFF. RASFF bevat 32 meldingen m.b.t. GGO in diervoeders in de periode 2010-2014, waarvan de meeste gevonden in choline chloride (uit China in 2014), katoenzaad en lijnzaad (Adamse et al., 2016). 


\subsubsection{Conclusie}

Voor PAK's zijn er geen wettelijke limieten in diervoeder en daarom ook weinig gegevens. Overdracht naar dierlijke producten is beperkt, dus PAK's lijken minder belangrijk voor humane gezondheid.

Hormonen kunnen een probleem opleveren in diervoeder indien er restromen van de farmaceutische industrie zijn gebruikt of via illegaal gebruik. GGO's kunnen via versleping in diervoeder terechtkomen of via restanten van GGO organismen in additieven. Incidenteel worden ook niet-toegelaten GGO's aangetroffen. 


\subsection{Dierlijke eiwitten}

\subsubsection{Bovine Spongiform Encephalopathy (BSE)}

BSE is de belangrijkste vorm binnen de groep van Transmissible Spongiform Encephalopathies (TSE's). Deze aandoeningen worden veroorzaakt door prionen. Prionen zijn stabiele versies van diereigen eiwitten die niet door enzymen kunnen worden afgebroken en accumuleren met name in de hersenen en het cerebrale systeem van herkauwers en enkele andere diersoorten. De epidemiologie en achtergrond zijn principieel anders dan andere dierziekten of ongewenste bestanddelen: prionziekten verlopen altijd progressief en zijn niet behandelbaar (Collins et al., 2004; Prince et al., 2003; Prusiner, 1998). Uitgebreide analyses toonden aan dat de meest waarschijnlijke route voor infectie verloopt via gecontamineerd voer, d.w.z. voer waar besmette dierlijke bijproducten in zijn verwerkt (Morley et al., 2003; Prince et al., 2003).

Verschillende procedures zijn ontwikkeld voor inactivatie van prionen in de diervoeder en voedsel productieketen, zoals composteren (Xu et al., 2014), chloridebehandeling en schoonmaak procedures (Hawkins et al., 2015), en hittebehandeling en zuur- of basebehandeling (Mekonnen et al., 2013). Geen enkele behandeling blijkt volledig effectief. Het EU-systeem van sterilisatie ( $133^{\circ} \mathrm{C}$ gedurende 20 min bij een druk van 3 bar) inactiveert 99,5\% van de prionen (RIVM richtlijn Creutzfeld Jacob). Alleen extreme behandelingen $\left(180^{\circ} \mathrm{C}\right.$ gedurende 3 uur) resulteert in volledige inactivatie (Yoshioka et al., 2013).

Chronic Wasting Disease (CWD) is een BSE gerelateerde prionziekte die voorkomt bij een aantal in het wild levende herkauwers, zoals elanden, rendieren en herten. CWD komt in toenemende mate voor bij herkauwers in het mid-westen van de Verenigde Staten en Canada (Evans et al., 2014; Haley and Hoover, 2015). In 2016 zijn er verschillende gevallen waargenomen in Noorwegen (twee in rendier en twee in eland; http://www.vetinst.no/sykdom-og-agens/chronic-wasting-disease/the-first-detectionof-chronic-wasting-disease-cwd-in-europe). Er is vastgesteld dat besmetting met CWD kan plaatsvinden via planten die prionen opgenomen hebben middels urine of kadavereiwitten van besmette dieren (Pritzkow et al., 2015). Omdat planten in staat zijn grote eiwitmoleculen via de wortels op te nemen, is opname van prionen in planten vanuit kadavers in theorie mogelijk (Rasmussen et al., 2014). Om verdere verspreiding te voorkomen wordt door EFSA aanbevolen om geen dode hertachtigen als aas te gebruiken en verplaatsing van ingekuild voer en diervoeders vanuit plaatsen waar CWD endemisch is te beperken (EFSA, 2017b). Het verband tussen CWD en BSE is nog niet aangetoond en de nu bekende transmissieroute kan gevolgen hebben voor de voedselproductieketen. In Nederland zijn sinds 198788 runderen afkomstig uit Nederland gevonden met een BSE-besmetting. Sinds 2013 zijn er geen nieuwe gevallen geconstateerd (World Organisation for Animal Health., 2017).

\subsubsection{Regulering}

$\mathrm{Na}$ de BSE-crisis is er een beperking gekomen op het voeren van dieren met de resten van andere dieren met als doel om TSE's te controleren en uit te roeien en nieuwe uitbraken met TSE's te voorkomen. Er worden drie klassen van dierlijke bijproducten onderscheiden op basis van de mogelijke schadelijke effecten. Categorie 1 materiaal heeft het hoogste risico en bevat materiaal zoals hele kadavers van dieren die vermoedelijke met een TSE zijn besmet (Verordening (EG) 1069/2009, artikel 8). Categorie 2 materiaal omvat dierlijke bijproducten zoals mest en dierlijke bijproducten die residuen van toegelaten stoffen of contaminanten bevatten die toegelaten niveaus overschrijden (artikel 9). Categorie 3 materiaal omvat dierlijke bijproducten zoals karkassen en delen van dieren die geschikt zijn voor menselijke consumptie, maar die om commerciële redenen niet voor menselijke consumptie bestemd zijn en dieren die geen symptomen vertonen van op mens of dier overdraagbare ziekten (artikel 10). Het gebruik van categorie 1 en 2 materiaal is niet toegestaan in diervoeder, categorie 3 materiaal is alleen toegestaan om te gebruiken als diervoederingrediënt in alle visvoeders, maar nog niet voor pluimvee en varkensvoeders (en herkauwers). Dierlijke eiwitten zijn in visvoer grotendeels vervangen door sojameel. Door de Verordening is ook het beginsel ingevoerd dat hoogrisicomateriaal niet aan landbouwhuisdieren mag worden vervoederd en dat materiaal afkomstig van dieren van een bepaalde soort niet aan dieren van dezelfde soort mag worden vervoederd (antikannibalisme). 
RASFF bevat 18 meldingen tussen 2005 en 2015 voor dierlijk eiwit in diervoeder. Het betrof hier voornamelijk de aanwezigheid van dierlijk eiwit (landdieren) in visvoer, dierlijk eiwit in melkvervangers voor kalveren en in varkensvoer. Daarnaast waren er 69 meldingen tussen 2005 en 2015 met betrekking tot botfragmenten. Deze botfragmenten werden voornamelijk aangetroffen in visvoer en vismeel (24 meldingen), in suikerbietpulp ( 8 meldingen in 2005) en bloed(meel) (10 meldingen). De aanwezigheid van botfragmenten in suikerbietpulp kan veroorzaakt worden door aanhangende grond, waarin beendermeel als kunstmest is gebruikt of door botfragmenten van overleden kleine dieren (EC, 2004).

Data uit het NP Diervoeder laten zien dat dierlijke eiwitten soms in herkauwersvoer gevonden worden (tussen 0 en 0,55\% van de monsters in de periode 2011-2016). Onderzoek aan verenmelen toont aan dat deze bijna altijd bot- en spierfragmenten bevatten. Bij het ontveren van pluimvee lijkt het onvermijdelijk dat stukjes bot, huid, en spier meekomen met de veren.

Risicomanagement is gericht op een verstrekkend verbod van dierlijke producten in met name herkauwervoeders in de EU, Verenigde Staten en China (Liu et al., 2011). Behalve maatregelen voor de interne markt van de EU zijn er met een reeks landen handelsafspraken, gebaseerd op een risicoanalyse van de status van controle in het betreffende derde land. De controle van BSE in Nederland verloopt volledig langs de Europese richtlijnen. Controle op de aanwezigheid van dierlijke bijproducten in diervoeders is jaarlijks onderdeel van het NVWA Nationaal Plan Diervoeders. De ontwikkeling van de risico's wordt periodiek door EFSA geanalyseerd.

\subsubsection{Conclusie}

Dierlijke eiwitten en botfragmenten in diervoeding zijn gevonden in nationale monitoring en gemeld in het RASFF systeem. Gezien de mogelijke drastische consequenties dient vinger aan de pols te worden gehouden en wordt medium prioriteit toebedeeld. Daarnaast dient het optreden van CWD in de gaten te worden gehouden. 


\subsection{Fysische gevaren}

Materialen die tot fysische gevaren in de diervoederketen kunnen leiden variëren van zand, glas en beton (stadsafval) tot bijproducten van de voedselbereiding die non-food materialen kunnen bevatten (Papargyropoulou et al., 2014). Via milieuverontreiniging kunnen micro- en nanodeeltjes (waaronder plastics) in de voedselketen terecht komen (Bouwmeester et al., 2015). Om aan de kwaliteitseisen te voldoen tijdens transport en opslag wordt voedsel bijna altijd verpakt. Ondanks dat voor verpakkingsmaterialen een nultolerantie geldt (Verordening (EG) 767/2009), is het haast niet te vermijden dat er resten van verpakkingen in diervoeder terecht komen. In de praktijk wordt door de NVWA een actiegrens van $0,15 \% \mathrm{w} / \mathrm{w}$ gehanteerd.

In de RASFF databank (2005 - 2015) zijn 20 meldingen aangetroffen voor fysische gevaren. Het betrof hier vreemde objecten zoals dode dieren, haren van dieren, plastic, glas en metaalfragmenten.

Eventuele aanwezigheid van fysische gevaren brengt een gevaar mee voor diergezondheid, maar niet direct voor humane gezondheid. De aanwezigheid van fysische verontreinigingen kan echter ook chemische gevaren met zich meebrengen. Het gebruik van verpakkingsmaterialen bijvoorbeeld heeft verschillende gevolgen, die in het volgende schema worden weergegeven (Figuur 6).

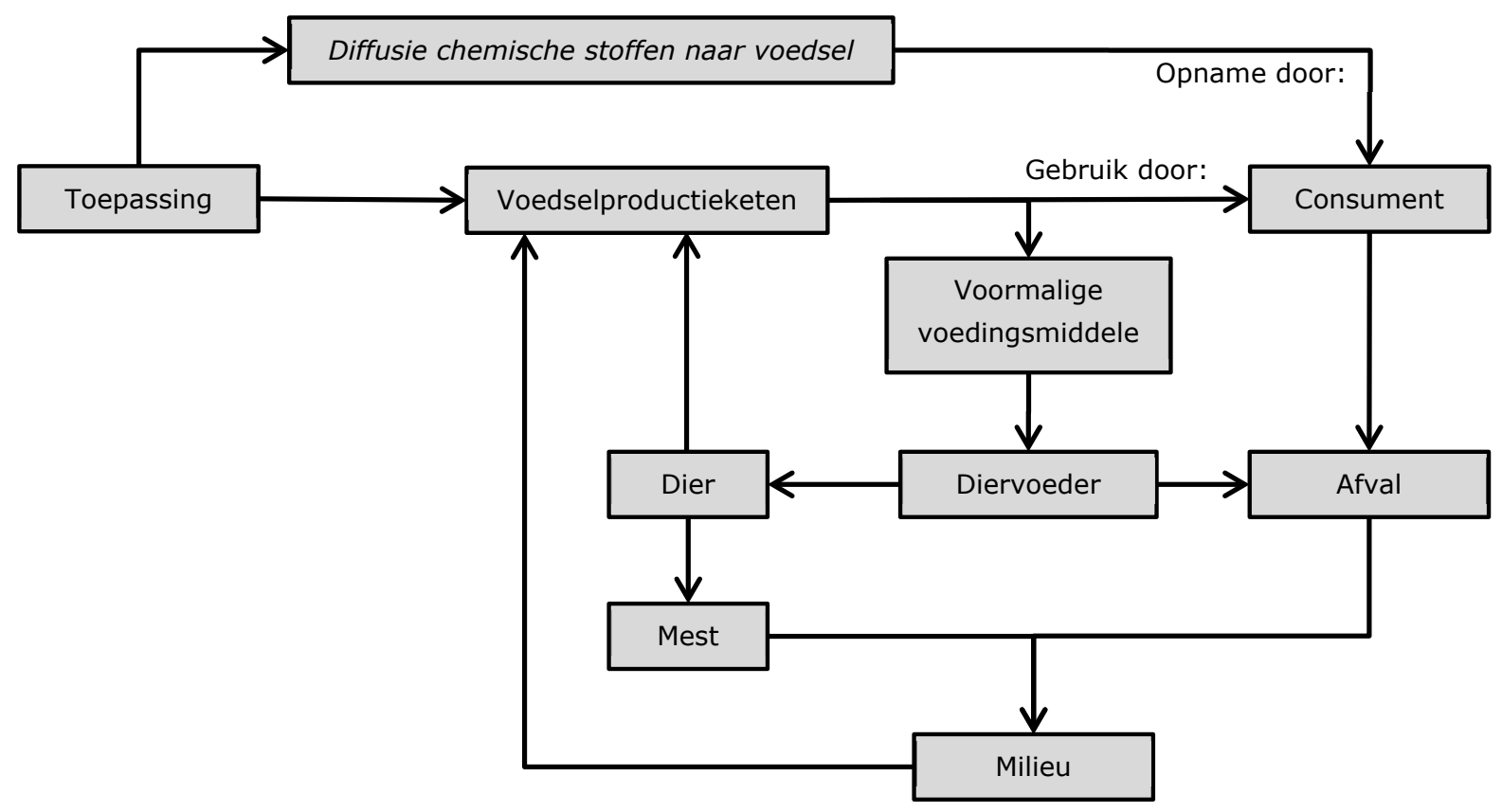

Figur 6 Keten van verpakkingsmateriaal.

\subsubsection{Restanten van verpakkingsmateriaal}

Restanten van verpakkingsmaterialen komen via het gebruik van voormalige voedingsmiddelen als diervoederingrediënt in de diervoederketen terecht. Deze restanten kunnen stoffen bevatten zoals weekmakers, bisphenol A of drukinkten. Wanneer landbouwhuisdieren dit binnenkrijgen, kan dit niet alleen een gezondheidsrisico voor het dier zelf vormen, maar via opname door het dier in de dierlijke producten en aldus in de voedselproductieketen terechtkomen. Ook kan verpakkingsmateriaal microen nanodeeltjes bevatten. Er zijn momenteel echter weinig gegevens over het optreden van deze stoffen in diervoeder, en de mogelijke humane blootstelling via diervoeder.

\subsubsection{Conclusie}

De belangrijkste fysische gevaren in diervoeder die mogelijk een risico kunnen vormen voor humane gezondheid is de mogelijke aanwezigheid van residuen van verpakkingsmateriaal die in het diervoeder terecht kunnen komen, en waarin stoffen als drukinkten, micro- en nanodeeltjes kunnen zitten. Er is echter weinig bekend over de introductie van deze stoffen via verpakkingsmaterialen in diervoeder, en over de overdracht van deze stoffen naar dierlijke producten. 


\section{$4 \quad$ Huidige monitoring}

De huidige monitoring van diervoeder in Nederland gaat via het Nationaal Plan (NP) Diervoeders van de NVWA en private monitoring uitgevoerd door deelnemers van SecureFeed. De huidige monitoring wordt in het algemeen risico-gebaseerd uitgevoerd. De private monitoring op aflatoxine B1 in maïs is sterk geïntensiveerd na het aflatoxine incident in maïs in 2013 (de Jong et al., 2016).

\section{Nationaal Plan Diervoeders}

NP Diervoeders is de uitwerking van de controleverordening, Verordening(EG) 882/2004 en omvat onderzoek op ongewenste stoffen, additieven en verboden materialen, GGO's, verboden dierlijke eiwitten, pesticiden en samenstelling in diervoeders. Het plan wordt elk jaar opgesteld voor het komende kalenderjaar en beschrijft het aantal monsters per diervoeder (grondstof), de aard en frequentie van controles. In 2017 zijn de volgende stoffen onderzocht (NVWA, 2017b):

- Verboden dierlijke eiwitten

- Mycotoxines; Aflatoxine B1 in plantaardige voedermiddelen (maïs) en DON/ZEA bij varkensvoeders. Maïs- en graskuilen en voeders voor volwassen zeugen zijn op 34 verschillende mycotoxines onderzocht

- Botanische onzuiverheden, (Ergot)alkaloïden en moederkoren met focus op rogge bevattende mengvoeders en granen

- Pyrrolizidine alkaloïden in luzerne

- Dioxines en dl-pcb's met focus op risico-producten zoals vetten en oliën, gedroogde plantaardige voedermiddelen, vismeel, minerale mengsels en additieven

- Minerale olie in oliën en vetten

- Bestrijdingsmiddelen met focus op enkelvoudige grondstoffen (granen, zaden, peulvruchten) en afgeleide producten (zoals plantaardige oliën), ook bij import

- Zware metalen met name risico-gericht op spoorelementen, fosfaten, kleimineralen, vismeel en minerale mengsels

- Coccidiostatica gericht op bedrijven die coccidiostatica voeders of ontwormingsmiddelen produceren

- Blauwzuur in lijnzaad

- Verpakkingsmateriaal

- Vetzuurpatroon

- Antibiotica met focus op de primaire sector (boerderij-fase), drinkwater en brijvoeders

- Ambrosia met focus op zaadmengsels voor buitenvogels

- GGO nadruk op vinden van aanwezigheid niet-toegelaten GGO's.

De onderzochte monsters en aantal overschrijdingen worden elk jaar gerapporteerd; het meeste recente jaarplan is uit 2017 (NVWA, 2017b). Elk jaar wijzigt het plan op basis van voortschrijdend inzicht en wordt naar specifieke productgroep-herkomstland combinaties gekeken.

\section{SecureFeed}

SecureFeed is een stichting waarvan de deelnemende Nederlandse diervoederbedrijven collectief de veiligheid van de diervoeders die zij leveren aan veehouders in Nederland waarborgen. Een collectief monitoringsplan over m.n. de ingekochte voedermiddelen (het SecureFeed Monitoringsplan

Diervoeders (SMD)) maakt deel uit van het SecureFeed Borgingssysteem. Het SMD is risicogebaseerd, en is dynamisch doordat handelsstromen per jaar variëren als gevolg van verandering in vraag en aanbod, en door weeromstandigheden. Het programma wordt minimaal jaarlijks geactualiseerd op basis van de daadwerkelijk hoeveelheid aangekochte voedermiddelen en risicobeoordelingen van voedermiddelen waarbij per grondstof/land van oorsprong combinatie informatie beschikbaar is over potentieel aanwezige contaminanten (de Jong et al., 2016). Voorbeelden hiervan zijn informatie over weersomstandigheden gedurende de teelt van gewassen, maar ook agronomische factoren, opslag en verwerking (drogen) en lokale wetgeving m.b.t. pesticiden en GGO's. Voor de meeste stoffen gelden wettelijke en GMP+ normen, maar SecureFeed kan bovenwettelijke normen hanteren in afstemming met de dierlijke productieketen. 
De frequentie van analyses hangt onder andere af van de kans en ernst van de geïdentificeerde risico's voor het product en van de totaal door SecureFeed deelnemers ingekochte hoeveelheid voedermiddelen. Alle SecureFeed analyses worden in een databank beheerd en zijn toegankelijk voor de deelnemers.

SecureFeed voert product/contaminant scores en risicoclassificaties uit en maakt deze jaarlijks up-todate. De oorsprong van grondstoffen word niet genoemd in de lijst, tenzij een bepaalde oorsprong een afwijkend risicoprofiel heeft, Deze risicoclassificatie gaat uit van HACCP-scores, waarbij de ernst van de contaminant en de waarschijnlijkheid dat een contaminant in het diervoeder terecht komt leidt tot een kleurcodering en cijfer volgens de onderstaande matrix:

\begin{tabular}{|l|l|l|l|l|}
\hline Ernst v/d contaminant $\downarrow$ & \multicolumn{5}{l|}{} \\
\cline { 1 - 4 } Groot (3) & 0 & 3 & 4 & 4 \\
\hline Matig (2) & 0 & 2 & 3 & 4 \\
\hline Klein (1) & 0 & 1 & 2 & 3 \\
\hline $\begin{array}{l}\text { Waarschijnlijk contaminant in } \\
\text { diervoeder } \rightarrow\end{array}$ & Afwezig (0) & Laag (1) & Midden (2) & Hoog (3) \\
\hline
\end{tabular}

De risicoklasse voor individuele contaminanten bepaalt de risicoklasse van het voedermiddel:

1. Minimaal éénmaal score 4 : uitgangsclassificatie Hoog

2. Minimaal tweemaal score 3 : uitgangsclassificatie Midden

3. Overige scores : uitgangsclassificatie Laag

Hoge prioriteit m.b.t. voedselveiligheid hebben met name dioxines, DL-PCB's en non-DL-PCB's in oliën en vetten van dierlijke en plantaardige oorsprong. In granen en (bij)producten van granen hebben mycotoxines (aflatoxine, DON en zearalenon) een hoge prioritering. Aan het begin van de oogst is er extra aandacht voor analyses van mycotoxines. Als fysiek gevaar worden botfragmenten en vuil gezien als hoge prioriteit in dierlijk vet (Securefeed, 2016a).

Naast voedselveiligheid speelt productintegriteit (komen de productkenmerken overeen met de gestelde specificaties) een rol bij het vast stellen van de finale risicoclassificatie van een diervoeder. De beoordeling op productintegriteit is een beoordeling op misleiding in benaming, samenstelling, etikettering en gevoeligheid voor fraude van een product en wordt als volgt gescoord:

- Fraudegevoeligheid (matrix Financieel Voordeel x Pakkans)

\begin{tabular}{|l|l|l|}
\hline \multicolumn{2}{|l|}{ Financieel voordeel $\downarrow$} & \\
\hline Hoog & H / K & H / G \\
\hline Laag & L/K & L/ G \\
\hline Pakkans $\rightarrow$ & Klein & Groot \\
\hline
\end{tabular}

- GGO kwesties: Zijn er GGO issues? : Ja / Nee

Om van de uitgangsclassificatie op basis van voedselveiligheid tot de feitelijke risicoclassificatie te komen, wordt de score op productintegriteit als volgt meegenomen:

- Score "H / K" bij fraudegevoeligheid >> Risicoclassificatie is een niveau boven uitgangsclassificatie

- Score "L / K" en "H / G" en GGO = "JA" >> Risicoclassificatie is een niveau boven uitgangsclassificatie

Leveranciers van voedermiddelen aan SecureFeed-deelnemers worden beoordeeld op veiligheid van hun producten en worden opgenomen in een databank. De intensiteit van de beoordeling (schriftelijk, audit leverancier, audit achterliggende schakels) is afhankelijk van de risicoklasse van de geleverde voedermiddelen. De risicoklasse van een leverancier is gelijk aan de hoogste risicoklasse van de 
voedermiddelen die hij levert ( $v b$. een leverancier met een hoog-risico product en tien laag-risico product, is een hoog-risicoleverancier). Nieuwe producten/leveranciers worden intensief gemonitord. Voor maïs geldt dat het land van herkomst vermeld moet worden bij het product. Maïs wordt onderverdeeld in laag (EU-5 (Nederland, Duitsland, België, Frankrijk, Luxemburg) of hoog risico (afkomstig uit rest van de wereld (overig Europa, Zuid-Amerika). Een van de moeilijkheden hierbij is dat een deel van de import weer wordt geëxporteerd. Dit gebeurt ook in andere landen, bijvoorbeeld maïs uit Servië (oorsprong) komt via Frankrijk (herkomst en veilig geacht) naar Nederland.

Bemonstering in de Nederlandse haven is voor aflatoxine B1 een verplichting vanuit GMP+. Voor mycotoxines geldt dat de eerste partijen van een oogst uit alle landen/regio's intensiever worden geanalyseerd. Hiervoor bestaat een speciaal monitoringsprogramma; collectieve monitoring mycotoxines granen nieuwe oogst.

Sommige bedrijven hanteren een eigen kleurencoderingssysteem voor het nemen van monsters en analyses uitvoeren op aflatoxine in maïs: groen geen probleem, blauw is risico voor overschrijding indien bestemd voor melkvee, rood is maïs die niet aan melkvee mag worden vervoederd maar wel aan andere diersoorten (de Jong et al., 2016).

\section{GMP+}

Het GMP+ monitoringsprogramma werd jaarlijks opgesteld op basis van onder andere analyseresultaten van het voorgaande jaar, het bijstellen van GMP+ normen en EWS (early-warning) signalen. Sinds 2013 is er echter geen GMP+ monitoringsprogramma meer uitgevoerd. GMP+ gecertificeerde bedrijven dienen echter wel hun eigen monitoring uit te voeren (de Jong et al., 2016). In 2013 lanceerde GMP+ een monitoringsdatabank, waarin GMP+ deelnemers hun monitoringsprogramma en data kunnen opslaan. De GMP+ databank bevat historie van analyseresultaten van >20 jaar en bevat gegevens over verplichte analyses waaronder aflatoxine B1 in maïs en maïsbijproducten, in voedermiddelen voor melkvee, dioxine en DL-pcb's in vetten en oliën, poortwachtersprotocollen zoals voor de aankoop van granen, zaden en peulvruchten. De monitoring richt zich op (de Jong et al., 2016):

- Ongewenste stoffen (Richtlijn 2002/32/EG): dioxinen en dl-pcb's, non-dl pcb's, mycotoxines (aflatoxine, DON, ochratoxine., zearalenon, fumonisinen), zware metalen (lood, cadmium, kwik, arseen), organochloorpesticiden, onvoorziene ongewenste stoffen

- Diermeel (verboden dierlijke eiwitten)

- GGO's (etikettering en niet toegelaten)

- Residuen pesticiden (Verordening (EG) 396/2005) 


\section{$5 \quad$ Preventie en controle}

De Verordening (EG) 178/2002 geeft voorschriften voor bedrijven die diervoeders produceren, vervaardigen, verwerken, opslaan, vervoeren of distribueren. Diervoeders zijn onveilig voor gebruik als ze nadelige effecten hebben op de dierlijke of menselijke gezondheid. Verwerkte diervoeders dienen gescheiden te worden gehouden van onverwerkte diervoeders en toevoegingsmiddelen om kruisbesmetting te vermijden. Materialen die gebruikt worden voor opslag en vervoer van mengvetten en oliën van plantaardige oorsprong of producten hiervan mogen niet gebruikt worden voor opslag of vervoer van andere producten of moeten tussentijds gereinigd worden om kruisbesmetting te voorkomen (Verordening (EG) 183/2005). In sommige gevallen hanteert de NVWA verslepingsnormen, bijvoorbeeld voor antibiotica in mengvoeders. Ook mogen toegelaten GGO's voor maximaal 0,9\% aanwezig zijn in diervoeder, zonder dat dit op het etiket vermeld hoeft te worden. Er zijn ook voorschriften voor traceerbaarheid van diervoeders. Zo moet de herkomst van de grondstof met naam en toenaam vermeld worden (Verordening (EG) 767/2009). Om dit alles te borgen maakt de diervoederindustrie gebruik van een aantal kwaliteitssystemen.

\section{Kwaliteitssystemen:}

GMP+ (Good Manufacturing Practices, de + staat voor integratie van HACCP) is een productie gerelateerde kwaliteitszorgbenadering van toepassing voor producenten en handelaren van mengvoeders, enkelvoudige diervoeders, vochtrijke voedermiddelen, voormengsels en diervoedergrondstoffen. Het GMP+ FSA certificaat is in Nederland ontwikkeld in samenwerking met de diervoederindustrie na incidenten met besmetting van voedermiddelen. Het is een internationaal schema beheerd door GMP+ International en bestaat uit een complete module voor borging van diervoederveiligheid in alle schakels van de diervoederketen (GMP+International, 2016). GMP+ werkt volgens een ketenbenadering; gecertificeerde bedrijven doen alleen zaken met bedrijven in de keten die ook GMP+ FSA gecertificeerd zijn. GMP+ International heeft in meer dan 85 landen ruim 15.700 GMP+ FSA-gecertificeerde bedrijven.

SecureFeed borgt de veiligheid van alle diervoeders en grondstoffen. Deelnemers zijn leveranciers van voedermiddelen, mengvoeders en additieven rechtstreeks aan veehouders. SecureFeed-deelnemers vertegenwoordigen $100 \%$ van de Nederlandse productie van mengvoeders, bijna $100 \%$ van de Nederlandse productie van vochtrijke diervoeders en ruim $80 \%$ van de fouragehandel (SecureFeed, 2016b). Deelnemers zijn verplicht maximale openheid te betrachten over mogelijke risico's voor de voeder- en/of voedselveiligheid, en calamiteiten worden geregistreerd. SecureFeed is een collectieve aanvulling en verdieping op bijvoorbeeld GMP+ FSA. Het monitoringsysteem is afgestemd op het risicoprofiel van diervoeders (SecureFeed, 2016b). SecureFeed kent actie-, en afkeurgrenzen bij overschrijdingen van limieten:

- Actiegrens: bij overschrijding actiegrens moet onderzoek gedaan worden naar oorzaak van de verontreiniging en moeten maatregelen genomen worden om de oorzaak van de verontreiniging weg te nemen of te beperken.

- Afkeurgrens: bij overschrijding van de afkeurgrens is het product niet geschikt om te worden gebruikt als voedermiddel of diervoeder.

Naast SecureFeed en GMP+ hebben grote bedrijven vaak hun eigen kwaliteitszorgsystemen. Voor biologische bedrijven geldt de regelgeving inzake biologische productie (met als controlerende instantie Skal); producten van agrarische oorsprong moeten biologisch zijn, er mogen geen antibiotica gebruikt worden, of andere medicinale stoffen en groeibevorderaars. Verder mogen alleen bepaalde niet-biologische ingrediënten, additieven en hulpstoffen worden gebruikt (Bijlage $V$ en VI van Verordening (EG) 889/2008) (SKAL, 2017).

\section{Traceerbaarheid}

Uit recent onderzoek naar de terugtracering blijkt dat traceerbaarheid van grondstoffen in de diervoedersector in het algemeen zeer goed geregeld is (de Jong et al., 2016). De bedrijven die aan 
het onderzoek meewerkten gaven aan dat waar je ook een meetpunt in de keten fixeert, het resultaat altijd hetzelfde is en je altijd bij de juiste leverancier of ontvanger uit komt (de Jong et al., 2016). Mogelijk draagt het eigen monitoringsprogramma (SecureFeed) hier aan bij, want een goede traceerbaarheid m.b.t de Nederlandse diervoederketen blijkt voor de NVWA niet uitvoerbaar te zijn (NVWA, persoonlijke communicatie). Voor oliën en vetten kan traceerbaarheid wel een probleem zijn omdat tanks gedeeltelijk worden geleegd en weer bijgevuld met nieuwe partijen. Partijen grondstoffen volgen uiteenlopende transportlijnen waaronder zeeschip, lichter, vrachtwagen, tanks of containers. Meestal vindt bemonstering en analyse plaats bij aankomst van de grondstof in een haven. De resultaten worden door de importeur aan de ontvangers doorgezonden. Diervoederfabrikanten nemen daarnaast ook zelf monsters, maar in het algemeen worden partijen niet meerdere keren geanalyseerd. Uitzonderingen hierop zijn in het rapport van de Jong benoemd en betreffen aflatoxine in maïs uit Brazilië en in maïsglutenpellets uit Hongarije, en dioxinen in palmolievetzuren (de Jong et al., 2016). 


\section{Toekomstige ontwikkelingen in de diervoederketen}

Er zijn verschillende trends waarneembaar in de diervoederketen die in de komende jaren kunnen leiden tot (nieuwe) chemische gevaren en tot verschuivingen in de bestaande gevaren. Deze trends zijn verkregen via literatuurstudie en via expertkennis. Een aantal trends (niet uitputtend) wordt hieronder kort benoemd.

\section{Alternatieve ingrediënten voor diervoeder}

Nederland is na China de grootse importeur van soja. Aangezien de duurzaamheid van soja ter discussie staat, is er een groeiende belangstelling voor productie van alternatieve eiwitbronnen in Europa.

Volledige vervanging van soja-eiwit is gezien de grote volumina, de hoge eiwitkwaliteit en de kosten op dit moment echter nog niet haalbaar. Alternatieven voor geïmporteerde soja zijn Europese schroten en eiwitrijke bijproducten. Wanneer soja vervangen wordt door andere plantaardige producten, zoals erwten en katoenzaad kan dit andere voedselveiligheidsgevaren met zich meebrengen.

Daarnaast wordt er steeds meer geïnvesteerd in andere alternatieve eiwitbronnen (zoals insecten, algen, zeewier) (Hilkens, 2015). Insecteneiwit kan in prijs en kwaliteit concurreren met visvoer en soja-eiwit (Hilkens et al., 2016). Momenteel mag insecteneiwit nog niet gebruikt worden in alle diervoeders omdat het hier gaat om dierlijk eiwit. In 2017 is door de Europese Commissie besloten dat insecteneiwit wel toegepast mag worden in voeders gebruikt in aquacultuur (Verordening (EU) 2017/893 (wijziging van Verordening (EG) 999/2001)). De verwachting is dat insecteneiwit in 2020 ook toegepast mag worden in diervoeders voor varkens en kippen. Momenteel mogen insectenolie en levende insecten al wel gebruikt worden in diervoeder voor kippen en varkens (Hilkens et al., 2016). Een verruiming van de BSE-wetgeving kan effect hebben op de chemische gevaren die kunnen voorkomen in diervoeder. Zo kunnen insecten zware metalen (Van der Fels-Klerx et al., 2016) en dioxines bevatten (NP Diervoeders, 2017) en verenmeel gemaakt van landdiermateriaal residuen van antibiotica (Berendsen et al., 2013b; Jansen et al., 2016).

$\mathrm{Er}$ is toename te zien in het gebruik van enzymen als diervoederadditief. Deze enzymen worden gebruikt om bijvoorbeeld de fosfaatemissie te reduceren of de verteerbaarheid van non-starch polysacchariden te verbeteren (Bundgaard et al., 2014). De hoeveelheid diervoederadditief in het uiteindelijke diervoeder is echter relatief gering.

\section{Verandering in voersamenstelling}

Het aandeel biologisch diervoeder neemt toe. Agruniek Rijnvallei, een van de grootste fabrikanten, voorziet voor de eigen afzet een stijging van 6.000 ton in 2015 naar 10.000 ton in 2016. Gebruik van biologisch voer zou mogelijk kunnen leiden tot toename van de gehalten van bepaalde mycotoxines. Mengvoeder wordt vaker vervangen door droge en natte bijproducten.

Daarnaast zijn er verschuivingen in de ingrediënten die gebruikt worden voor het maken van mengvoeders. Zo wordt het aandeel plantaardige ingrediënten in visvoer steeds hoger. De verwachting is dat in 2020 de inclusion rate van visolie in visvoer nog slechts $8 \%$ is. In 2006 was dit percentage nog 20-30\%. Dit betekent een lagere blootstelling van vissen en visetende consumenten aan contaminanten zoals dioxines, dl-PCB's en vlamvertragers (Berntssen et al., 2011a). Economische ontwikkelingen zorgen ervoor dat bijvoorbeeld GGO-gewassen (soja) in diervoeders vervangen worden door andere, minder dure, gewassen. Andere ingrediënten kunnen andere gevaren opleveren. Hier zal rekening mee gehouden moeten worden, opdat bepaalde gevaren niet over het hoofd gezien worden.

\section{Hergebruiken van grondstoffen}

Een van de manieren om grondstoffen te verduurzamen is in te zetten op circulaire economie, waarbij grondstoffen en producten maximaal hergebruikt worden. Het volledig sluiten van de kringloop voor diervoeders is lastig omdat Europa nog grotendeels afhankelijk is van import uit derde landen. Een van de pijlers waar momenteel op ingezet wordt, is de reductie van voedselverlies en -verspilling. Er zal in de toekomst dus meer gebruikgemaakt worden van VVM. In Canada en de VS worden VVM al gebruikt om insecten te voeren, die vervolgens gebruikt worden als diervoeder (Kiser et al., 2016). 
Ook worden bijproducten uit de levensmiddelen- en bio-ethanolindustrie verwaard tot diervoeder (NEVEDI, 2016a). Dit kan voedselveiligheidsgevaren met zich meebrengen. Zo bevatten bijproducten uit de graanverwerkende industrie (zoals gries en schroot) hogere concentraties mycotoxines in de eindproducten in vergelijking met de oorspronkelijke granen.

\section{Klimaatverandering}

Verwacht wordt dat door klimaatveranderingen ook de weide-onkruiden zullen veranderen. Een aantal onkruidsoorten bevat planttoxines. Deze komen nu niet voor in Nederland, maar kunnen door klimaatverandering invasief worden (Chown et al., 2014). Verder kunnen de concentraties van de planttoxines sterk gaan wisselen door langere periodes van droogte, regen of insectenplagen. Verder is klimaatverandering (opwarming, droogte, hoosbuien en overstromingen) in verschillende delen van de wereld gunstig voor de ontwikkeling van schimmels die mycotoxines produceren (Marroquín-Cardona 2014). Hierdoor zullen mycotoxines mogelijk vaker in diervoeder aangetroffen worden. In het kader van voedselzekerheid is detoxificatie (ontgiften) van met mycotoxines besmette grondstoffen een opkomende trend. Dit leidt mogelijk tot het optreden van bepaalde voedselveiligheidsgevaren. Wanneer mycotoxinebinders gebruikt worden als diervoederadditief kunnen zware metalen in het diervoeder geïntroduceerd worden (zie 3.2.3.2).

\section{Toenemende vraag naar dierlijke producten}

Naast de klimaatverandering zijn andere ontwikkelingen gaande waardoor de kwaliteit van diervoeder onder druk komt te staan. Voorbeelden hiervan zijn de hogere vraag naar dierlijke producten zoals vlees en melk en daarmee diervoeder, wereldwijde handel, lange-afstandstransporten, grotere verpakkingen en een langere opslag van grote batches (Makkar and Ankers 2014). De diervoedersector moet innoveren om tegemoet te komen aan de toenemende vraag naar dierlijk eiwit en de eisen tot vermindering van stikstof-, fosfor- en koolstofdioxide-emissies (Anonymous, 2015).

\section{Toename in aantal zelfmengers}

Vanwege de "stoppersregeling" is te verwachten dat veel (kleinere) varkens- en pluimveebedrijven stoppen richting 2020. Dit zijn bedrijven die volledig mengvoeder gebruiken waardoor de productie en handel van mengvoeder zal verminderen. Grote bedrijven gaan in toenemende mate zelf mengen (Stevens, 2016). Het aantal bedrijven dat eigen mengvoeders maakt, de zelfmengers, zal de komende jaren toenemen (Arkervaart-BramecoZon, 2017; Stevens, 2016). Momenteel wordt ca. 140.000 ton mengvoeder geproduceerd door zelfmengers. In 2011 was dit nog maar 40.000 ton. Ook kunnen varkenshouders via websites als mijnvoer.nl hun recepturen doorgeven en de site geeft dan aan waar het voer het goedkoopst gemaakt kan worden (Stevens, 2016). Dit voer wordt ingekocht bij producenten die een NVWA-registratie en een GMP+ erkenning bezitten.

\section{Toename in technologische ontwikkelingen}

$\mathrm{Er}$ is een groeiende interesse in het gebruik van peptiden in diervoeder. Deze peptiden worden verkregen door hydrolisering van dierlijke eiwitten. Peptiden verbeteren de voederconversie en groei van landbouwhuisdieren (Hou et al., 2017). Door de hydrolyse is het lastiger om de herkomst van de eiwitten vast te stellen wat traceerbaarheid naar diersoort bemoeilijkt en fraude in de hand kan werken.

\section{Overige ontwikkelingen}

- Door de trage toelatingsprocedure van GGO-gewassen in de EU (asynchrone toelating EU t.o.v. rest van de wereld)), maar ook door het aantal testen met nieuwe GGO-gewassen, waarvan er maar een deel uiteindelijk naar de markt zal gaan en de nieuwe ontwikkelingen in plantenveredeling (gene drives, CRISPR-CAS) waarvoor de GGO-regelgeving in de EU nog niet is aangepast, zal de kans dat geïmporteerde voederproducten niet-toegelaten GGO's bevatten toenemen (FAO, 2014).

- Het wordt steeds makkelijker om in de EU verboden diergeneesmiddelen en hormonen die buiten de EU wel zijn toegelaten te bestellen via internet en zelf te mengen door het voer (of drinkwater).

- Door het verbod op gebruik van antibiotica in voeders wordt door boeren mogelijk vaker gebruik van alternatieve geneeswijzen, waaronder het gebruik van kruiden. Ook wordt topdressing waarschijnlijk vaker toegepast met mogelijke gevolgen voor homogene verdeling van antibiotica en residuen in dierlijke producten. 
- Er is een trend richting meer lokale grondstoffen (NEVEDI, 2016a). Eventuele lokale besmettingen kunnen dan leiden tot hogere concentraties in het uiteindelijke diervoeder door minder verdunning met schone ingrediënten. 


\section{$7 \quad$ Conclusies en aanbevelingen}

Op basis van mogelijke aanwezigheid van gevaren in diervoedergrondstoffen en diervoeders, mogelijke overdracht van deze gevaren naar dierlijke producten én toxiciteit van de gevaren kan een indicatie gegeven worden van stoffen die in het monitoringsprogramma voor diervoeder opgenomen zouden moeten worden vanwege mogelijke effecten op volksgezondheid (de short-list). Voor sommige stoffen kunnen overschrijdingen gevonden worden die geen of weinig effect hebben op de volksgezondheid. Dit geldt bijvoorbeeld voor pesticiden. Deze stoffen komen niet op de short-list, maar kunnen wel vanwege andere (bijvoorbeeld economische, milieu of politieke) redenen worden opgenomen in de nationale monitoring.

Naar aanleiding van de evaluatie van mogelijke chemische en fysische gevaren (H3) - op basis van optreden, overdracht naar dierlijke producten en toxiciteit voor de mens - staan de volgende stoffen op de short-list: dioxines, aflatoxines (hoge prioriteit), PA's (hoge prioriteit) en de zware metalen cadmium, lood, kwik en arseen (medium prioriteit). Zware metalen hopen vooral op in lever en nieren, i.e. producten die in mindere mate door de mens worden geconsumeerd en zijn dus in die zin minder belangrijk dan dioxines en aflatoxines, die ophopen in dierlijke producten die veel geconsumeerd worden. PA's hebben hoge prioriteit omdat zij regelmatig worden aangetroffen in diervoeder, soms in hoge concentraties, worden overdragen naar melk, eieren en vlees en omdat een aantal PA's toxisch zijn voor de mens.

Sub-ketens van belang voor dioxines zijn: verwerking van plantaardige producten $2^{\mathrm{e}}$ fase (c), verwerking van dierlijke producten, met name van maritieme oorsprong (e), verwerking bijproducten tot voedermiddelen ( $f$ ) en chemische additieven, zoals kleimineralen $(g)$. Voor aflatoxines zijn vooral de plantaardige producten van belang: primaire plantaardige producten (a) en invoer, import en verwerking plantaardige producten (b). Voor zware metalen zijn verwerkte dierlijke producten van belang, met name van maritieme oorsprong (e), verwerking bijproducten tot voedermiddelen ( $f$ ) en chemische additieven, zoals kleimineralen $(\mathrm{g})$. PA's worden geïntroduceerd in de primaire plantaardige keten (a), en zijn van belang in alle overige sub-ketens de met deze sub-keten samenhangen. Verder staan dierlijke eiwitten ook op de short-list (medium prioriteit). Diermeel verontreinigingen worden weinig gevonden maar vanwege de mogelijke ernst/impact kan het van belang zijn ook dierlijke eiwitten te monitoren in verwerking van dierlijke producten (e) en verwerking bijproducten tot voedermiddelen (f). Vanwege politieke redenen kan het van belang zijn de niet in de EU toegelaten GGO's in importstromen te monitoren. Daarnaast zijn een aantal andere stoffen van belang vanwege dierwelzijn- en gezondheid en milieu overwegingen of resistentie problematiek; deze vallen echter buiten de scope van onderhavige studie.

Voor een aantal stoffen zijn geen wettelijke limieten vastgesteld in diervoeder. Als gevolg hiervan zijn er weinig gegevens over het voorkomen van deze stoffen in diervoeder. Om te beoordelen of deze stoffen op de short-list moeten worden opgenomen zijn dan ook meer gegevens nodig. Het betreft hier: vlamvertragers, perfluorverbindingen, de meeste planttoxines (behalve PA's), minerale oliën en procescontaminanten. Andere kennisleemtes die in dit onderzoek naar voren kwamen waren:

- Nanodeeltjes in verwerkte plantaardige producten (b)

- Het voorkomen van SRM-pesticiden, zoals chloormequat, paraquat, diquat in diervoeder. M.b.v. analyses zou onderzocht moeten worden in hoeverre deze pesticiden gebruikt worden in diervoedergewassen en of deze tot residuen leiden in het diervoeder.

- De natuurlijke aanwezigheid van chlooramfenicol in gras is onbekend.

- Het is onbekend hoeveel ruwvoer buiten de officiële handel wordt verhandeld.

- De mate waarin grondstoffen via een ander Europees land de EU binnenkomen, en her-labelled worden, en de consequenties voor monitoring.

- Optreden van CWD.

Momenteel voert de NVWA de monitoring op diervoeders uit zoals is vastgelegd in het Nationaal Plan Diervoeders, waarin het aantal monsters is vastgelegd, en de aard en de frequentie van de controles. Dit plan wordt jaarlijks bijgesteld. De diervoedersector voert hun eigen monitoring uit en borgt de 
voederveiligheid via kwaliteitssystemen als GMP+ en/of door deelname aan Securefeed. Securefeed voert een risicogebaseerde monitoring uit waarbij stoffen in een risicoklasse geplaatst worden o.b.v. ernst en voorkomen van de stoffen. Volgens deze classificatie hebben met name dioxines, DL-PCB's en NDL-PCB's in oliën en vetten van dierlijke en plantaardige oorsprong een hoge prioriteit voor monitoring. In granen en (bij)producten van granen hebben mycotoxines (aflatoxine, DON en zearalenon) een hoge prioritering. Dit komt overeen met de bevindingen in dit rapport. Als fysiek gevaar worden botfragmenten en vuil gezien als hoge prioriteit in dierlijk vet (Securefeed, 2016a).

Er zijn verschillende trends waargenomen die een effect kunnen hebben op de voedselveiligheid van diervoeder. Er is meer aandacht voor duurzaamheid, waardoor er gezocht wordt naar alternatieve eiwitbronnen voor diervoeder, zoals insecten, algen en zeewier en steeds meer bij- en wellicht restproducten vanuit de circulaire economie worden hergebruikt. Deze ontwikkelingen kunnen leiden tot nieuwe voedselveiligheidsgevaren of het ophopen van gevaren. Andere belangrijke ontwikkelingen zijn de klimaatverandering wat een effect kan hebben op de gehalten aan mycotoxines en planttoxines en de toenemende vraag naar diervoeder, wat een effect kan hebben op de kwaliteit van het voer. Verder is er een toename in het aantal zelfmengers gesignaleerd, waardoor er minder grip is op de eindkwaliteit van het voer. Ook wordt er waarschijnlijk vaker gebruik gemaakt van topdressing van antibiotica waardoor er minder grip is op juiste toepassing. Al deze trends dienen dan ook nauwlettend gevolgd te worden om mogelijke problemen in de toekomst te voorkomen. 


\section{Dankwoord}

De studie beschreven in onderhavig rapport is gefinancierd door de Nederlandse Voedsel en Waren Autoriteit (NVWA). De auteurs danken Maryvon Noordam voor opmerkingen en suggesties bij de tekst, en SecureFeed voor gebruik van private monitoringsgegevens. 


\section{Literatuur}

Abraham, K., Appel, K., Berg, K., Heinemeyer, G., Lahrssen-Wiederholt, M., Lange, N., Lindtner, O., Schafft, H., Spolders, M., Vieth, B., Weissenborn, A., Wittkowski, R., 2011. Review: Die Vorkommnisse um Dioxin in Futtermitteln in Deutschland 2011- Gab es ein Risiko für Verbraucher? Journal of Food Safety and Food Quality 62, 105-144.

Adamse, P., De Jong, J., Jongbloed, A.W., Van Raamsdonk, L.W.D., Van Egmond, H., 2007. Trendanalyse van gehalten aan aflatoxine B1 en dioxinen/dioxine-achtige PCB's in diervoeders. RIKILT, Wageningen, the Netherlands, p. 49 p.

Adamse, P., Driessen, J.J.M., De Jong, J., Van Polanen, A., Van Egmond, H.J., Jongbloed, A.W., 2009a. Trendanalyse zware metalen in diervoeder(grondstoffen). RIKILT, Wageningen, the Netherlands, p. 108 p.

Adamse, P., Peters, R.J.B., Van Egmond, H.J., De Jong, J., 2014. Occurence and trend analysis of organochlorine in animal feed. RIKILT, Wageningen, the Netherlands, p. 41 p.

Adamse, P., Van der Fels-Klerx, H.J., de Jong, J., 2017. Cadmium, lead, mercury and arsenic in animal feed and feed materials - trend analysis of monitoring results. Food Additives \& Contaminants: Part A, null-null.

Adamse, P., Van der Fels-Klerx, H.J., Schoss, S., de Jong, J., Hoogenboom, R.L., 2015. Concentrations of dioxins and dioxin-like PCBs in feed materials in the Netherlands, 2001-11. Food additives \& contaminants. Part A, Chemistry, analysis, control, exposure \& risk assessment 32, 1301-1311.

Adamse, P., Van Egmond, H.P., Van Polanen, A., Bikker, P., de Jong, J., 2011. Trend analysis of copper and zinc in animal feed. RIKILT Wageningen UR, Wageningen, the Netherlands, p. 34 p.

Adamse, P., Van Raamsdonk, L.W.D., Van Egmond, H., De Jong, J., 2009b. Trendanalyse dierlijke eiwitten in diervoeder(grondstoffen). RIKILT, Wageningen, the Netherlands, p. 32 p.

Anonymous, 2015. Nutreco: flinke efficiëntieslag in productie dierlijke eiwitten, Food Valley Update.

Arkervaart-BramecoZon, C., 2017. Jaarverslag 2016, p. 52 p.

Aspenström-Fagerlund, B., Nordkvist, E., Törnkvist, A., Wallgren, P., Hoogenboom, R., Berendsen, B., Granelli, K., 2016. Distribution of chloramphenicol to tissues, plasma and urine in pigs after oral intake of low doses. Food Additives \& Contaminants: Part A 33, 1411-1420.

Battacone, G., Nudda, A., Pulina, G., 2010. Effects of Ochratoxin A on Livestock Production. Toxins 2, 1796-1824.

Bell, J.G., Dick, J.R., Strachan, F., Guy, D.R., Berntssen, M.H.G., Sprague, M., 2012. Complete replacement of fish oil with a blend of vegetable oils affects dioxin, dioxin-like polychlorinated biphenyls (PCBs) and polybrominated diphenyl ethers (PBDEs) in 3 Atlantic salmon (Salmo salar) families differing in flesh adiposity. Aquaculture 324, 118-126.

Benchaar, C., Calsamiglia, S., Chaves, A.V., Fraser, G.R., Colombatto, D., McAllister, T.A., Beauchemin, K.A., 2008. A review of plant-derived essential oils in ruminant nutrition and production. Anim Feed Sci Tech 145, 209-228.

Berendsen, B., Pikkemaat, M., Römkens, P., Wegh, R., van Sisseren, M., Stolker, L., Nielen, M., 2013a. Occurrence of chloramphenicol in crops through natural production by bacteria in soil. J Agric Food Chem. 61, 4004-4010.

Berendsen, B.J.A., Bor, G., Gerritsen, H.W., Jansen, L.J.M., Zuidema, T., 2013b. The disposition of oxytetracycline to feathers after poultry treatment. Food Additives \& Contaminants: Part A 30, 2102-2107.

Bernard, A., Hermans, C., Broeckaert, F., De Poorter, G., De Cock, A., Houins, G., 1999. Food contamination by PCBs and dioxins. 401, 231-232.

Berntssen, M.H.G., Maage, A., Julshamn, K., Oeye, B.E., Lundebye, A.K., 2011a. Carry-over of dietary organochlorine pesticides, PCDD/Fs, PCBs, and brominated flame retardants to Atlantic salmon (Salmo salar L.) fillets. Chemosphere 83, 95-103.

Berntssen, M.H.G., Valdersnes, S., Rosenlund, G., Torstensen, B.E., Zeilmaker, M.J., van Eijkeren, J.C.H., 2011b. Toxicokinetics and carry-over model of a-hexabromocyclododecane (HBCD) from feed to consumption-sized Atlantic salmon (Salmo salar). Food Additives \& Contaminants: Part A 28, 1274-1286. 
Binder, E.M., Tan, L.M., Chin, L.J., Handl, J., Richard, J., 2007. Worldwide occurrence of mycotoxins in commodities, feeds and feed ingredients. Anim Feed Sci Tech 137, 265-282.

Blanco, S.L., Martínez, A., Porro, C., Vieites, J.M., 2011. Dietary uptake of polybrominated diphenyl ethers (PBDEs), occurrence and profiles, in aquacultured turbots (Psetta maxima) from Galicia, Spain. Chemosphere 85, 441-447.

Bonadies, F., Berardi, G., Nicoletti, R., Romolo, F.S., De Giovanni, F., Marabelli, R., Santoro, A., Raso, C., Tagarelli, A., Roperto, F., Russo, V., Roperto, S., 2011. A new, very sensitive method of assessment of ptaquiloside, the major bracken carcinogen in the milk of farm animals. Food Chemistry 124, 660-665.

Bouwmeester, H., Hollman, P.C., Peters, R.J., 2015. Potential Health Impact of Environmentally Released Micro- and Nanoplastics in the Human Food Production Chain: Experiences from Nanotoxicology. Environmental science \& technology 49, 8932-8947.

Brera, C., Peduto, A., Debegnach, F., Pannunzi, E., Prantera, E., Gregori, E., De Giacomo, M., De Santis, B., 2013. Study of the influence of the milling process on the distribution of deoxynivalenol content from the caryopsis to cooked pasta. Food Control 32, 309-312.

Brühl, L., 2016. Occurrence, determination, and assessment of mineral oils in oilseeds and vegetable oils. Eur. J. Lipid Sci. Technol. 118, 361-372.

Buck, R.C., Franklin, J., Berger, U., Conder, J.M., Cousins, I.T., de Voogt, P., Jensen, A.A., Kannan, K., Mabury, S.A., van Leeuwen, S.P.J., 2011. Perfluoroalkyl and polyfluoroalkyl substances in the environment: Terminology, classification, and origins. Integr Environ Assess Manag 7, 513-541.

Bulder, A.S., Hoogenboom, L.A.P., Kan, C.A., Van Raamsdonk, L.W.D., Traag, W.A., Bouwmeester, H., 2006. Initial Risk Assessment of Polycyclic Aromatic Hydrocarbons (PAHs) in Feed (materials). RIKILT, Wageningen, the Netherlands, p. 43 p.

Bundgaard, A.M., Dalgaard, R., Gilbert, C., Thrane, M., 2014. Assessment of the potential of digestibility-improving enzymes to reduce greenhouse gas emissions from broiler production. Journal of Cleaner Production 73, 218-226.

Camardo Leggieri, M.C., Bertuzzi, T., Pietri, A., Battilani, P., 2015. Mycotoxin occurrence in maize produced in Northern Italy over the years 2009-2011: focus on the role of crop related factors. Phytopathol Mediterr 54, 212-221.

CAST, 2003. Mycotoxins: Risks in plant, animal, and human systems. Task Force Report 139, p. 199.

Chenchen, W., Wenlong, W., Xiaoxue, L., Feng, M., Dandan, C., Xiaowen, Y., Shanshan, W., Pengshuai, G., Hao, L., Baoyu, Z., 2014. Pathogenesis and preventive treatment for animal disease due to locoweed poisoning. Environmental toxicology and pharmacology 37, 336-347.

CLO, 2013. Jaarlijkse ophoping van zware metalen in de bodem, in: Leefomgeving, C.v.d. (Ed.).

Collins, S.J., Lawson, V.A., Masters, C.L., 2004. Transmissible spongiform encephalopathies. The Lancet 363, 51-61.

Constable, P.D., Hinchcliff, K.W., Done, S.H., Grünberg, W., 2016. Diseases of the respiratory System, in: Constable, P.D., Hinchcliff, K.W., Done, S.H., Grünberg, W. (Eds.), Veterinary Medicine E-BOOK: A Textbook of the Diseases of Cattle, Horses, Sheep, Pigs and Goats Elsevier, St Louis, Missouri, USA, pp. 845-1095.

Cook, D., Oliveira, C.A., Gardner, D.R., Pfister, J.A., Riet-Correa, G., Riet-Correa, F., 2015. Changes in swainsonine, calystegine, and nitrogen concentrations on an annual basis in Ipomoea carnea. Toxicon 95, 62-66.

Crout, N.M.J., Beresford, N.A., Dawson, J.M., Soar, J., Mayes, R.W., 2004. The transfer of 73As, $109 \mathrm{Cd}$ and $203 \mathrm{Hg}$ to the milk and tissues of dairy cattle. The Journal of Agricultural Science 142 203-212.

Davies, B.E., Crews, H.M., 1983. The contribution of heavy metals in potato peel to dietary intake. Science of The Total Environment 30, 261-264.

de Jong, J., van der Roest, J., Meurs, I., 2016. Landkaart monitoring diervoeders NL. RIKILT Wageningen UR.

de Nijs, M., Mulder, P.P.J., Klijnstra, M.D., Driehuis, F., Hoogenboom, R., 2017. Fate of pyrrolizidine alkaloids during processing of milk of cows treated with ragwort. Food additives \& contaminants. Part A, Chemistry, analysis, control, exposure \& risk assessment, 1-8.

de Rijk, T.C., van Egmond, H.P., van der Fels-Klerx, H.J., Herbes, R., de Nijs, M., Samson, R.A., Slate, A.B., van der Spiegel, M., 2015. A study of the 2013 Western European issue of aflatoxin contamination of maize from the Balkan area. World Mycotoxin Journal 8, 641-651. 
Devanaboyina, N., Rao, S.V.R., Panda, A.K., Sastry, V.R.B., 2007. Cottonseed meal in poultry diets: a review. Journal of Poultry Science 44, 119-134.

Diaz, G.J., Almeida, L.X., Gardner, D.R., 2014. Effects of dietary Crotalaria pallida seeds on the health and performance of laying hens and evaluation of residues in eggs. Res Vet Sci 97, 297-303.

Dickinson, J.O., Cooke, M.P., King, R.R., Mohamed, P.A., 1976. Milk Transfer of Pyrrolizidine Alkaloids in Cattle. J Am Vet Med Assoc 169, 1192-1196.

Dierengezondheidszorg_Vlaanderen_(DGZ), 2013. Een bijzonder geval van schapensterfte. http://www.dgz.be/nieuwsbericht/een-bijzonder-geval-van-schapensterfte.

Diletti, G., Ceci, R., Conte, A., De Benedictis, A., Migliorati, G., Scortichini, G., 2008. Milk Contamination from Dioxins in Italy: Source Identification and Intervention Strategies, in: Mehmetli, E., Koumanova, B. (Eds.), The Fate of Persistent Organic Pollutants in the Environment. Springer Netherlands, Dordrecht, pp. 301-314.

Driehuis, F., Spanjer, M.C., Scholten, J.M., te Giffel, M.C., 2008. Occurrence of mycotoxins in feedstuffs of dairy cows and estimation of total dietary intakes. Journal of dairy science 91 , 4261-4271.

EC, 2004. Summary Minutes of the Meeting of the Standing Committe on the Food Chain and Animal Health, p. 7 p.

EFSA, 2012. Cadmium dietary exposure in the European population. EFSA journal 10, 2551.

EFSA, 2014. Scientific Opinion on the risks for human and animal health related to the presence of modified forms of certain mycotoxins in food and feed. EFSA Panel on Contaminants in the Food Chain. EFSA Journal 12(12):3916, p. 107.

EFSA, 2015. Scientific Opinion on the risks to animal and public health and the environment related to the presence of nickel in feed. EFSA journal 13, 4074.

EFSA, 2016. Appropriateness to set a group health-based guidance value for zearalenone and its modified forms. EFSA Panel on Contaminants in the Food Chain. EFSA Journal 14(4):4425, p. 46.

EFSA, 2017a. Appropriateness to set a group health based guidance value for T2 and HT2 toxin and its modified forms. EFSA Journal 15(1):4655, p. 53.

EFSA, 2017b. Scientific Opinion Chronic wasting disease (CWD) in cervids. EFSA Journal 15(1):4667, p. 62.

EFSA, 2010. Scientific Opinion on Polybrominated Biphenyls (PBBs) in Food. EFSA journal 8.

EFSA, 2011. Scientific opinion on the risk to public health related to the presence of high levels of dioxins and dioxin-like PCBs in liver from sheep and deer. EFSA journal 9, 1-71.

EFSA, 2011a. Scientific Opinion on Hexabromocyclododecanes (HBCDDs) in Food. EFSA journal 9.

EFSA, 2011b. Scientific Opinion on Polybrominated Diphenyl Ethers (PBDEs) in Food. EFSA journal 9.

EFSA, 2011c. Scientific Opinion on Tetrabromobisphenol A (TBBPA) and its derivatives in food. EFSA journal 9.

EFSA, 2012. Scientific Opinion on Mineral Oil Hydrocarbons in Food. EFSA journal 10.

EFSA, 2012a. Scientific Opinion on Brominated Flame Retardants (BFRs) in Food: Brominated Phenols and their Derivatives. EFSA journal 10.

EFSA, 2012b. Scientific Opinion on Emerging and Novel Brominated Flame Retardants (BFRs) in Food. EFSA journal 10.

EFSA, 2016a. The 2014 European Union report on pesticide residues in food. EFSA journal 14.

EFSA, 2016b. Risks for human health related to the presence of 3- and 2-monochloropropanediol (MCPD), and their fatty acid esters, and glycidyl fatty acid esters in food. EFSA journal 14.

Eurostat, 2016. Agriculture data http://ec.europa.eu/eurostat/web/agriculture/data.

Evans, T.S., Schuler, K.L., Walter, W.D., 2014. Surveillance and Monitoring of White-Tailed Deer for Chronic Wasting Disease in the Northeastern United States. Journal of Fish and Wildlife Management 5, 387-393.

FAO, 2012. Biofuel co-products as livestock feed - Opportunities and challenges. FAO Rport ISBN 97892-5-107299-8.

Fediol., 2016. Fediol code of practice for the management of mineral oil hydrocarbons presence in vegetable oils and fats intended for food uses. Fediol.

FEFAC, 2015. Annual report 2014-2015. European Feed Manufactures'Federation

Fernandes, A.R., Mortimer, D., Rose, M., Smith, F., Panton, S., Garcia-Lopez, M., 2016. Bromine content and brominated flame retardants in food and animal feed from the UK. Chemosphere 150, 472-478. 
Ferrario, J., Byrne, C., Winters, D., Boone, T., Vigo, C., Dupuy, A., 2003. Chlorinated dioxins and furans from kelp and copper sulfate: Initial envestigations of dioxin formation in mineral feed supplements. Organohalogen Compounds 63, 183-186.

Fink-Gremmels, J., 2012. Introduction to animal feed contamination Chapter 1. Animal feed contamination -Effects on livestock and food safety Woodhead Publishing Limited, 2012, 1-10.

FitzGerald, L.M., Fletcher, M.T., Paul, A.E.H., Mansfield, C.S., O'Hara, A.J., 2011. Hepatotoxicosis in dogs consuming a diet of camel meat contaminated with indospicine. Aust Vet J 89, 95-100.

Flores-Flores, M.E., Lizarraga, E., López de Cerain, A., González-Peñas, E., 2015. Presence of mycotoxins in animal milk: A review. Food Control 53, 163-176.

Frohne, D., Pfänder, H., 2005. Poisonous Plants: A Handbook for Doctors, Pharmacists, Toxicologists, Biologists and Veterinarians.

Gatta, D., Russo, C., Giuliotti, L., Mannari, C., Picciarelli, P., Lombardi, L., Giovannini, L., Ceccarelli, N., Mariotti, L., 2013. Influence of partial replacement of soya bean meal by faba beans or peas in heavy pigs diet on meat quality, residual anti-nutritional factors and phytoestrogen content. Archives of Animal Nutrition 67, 235-247.

GMP+International, 2016. GMP+ International, https://www.gmpplus.org/pagina/288/home_un.aspx.

Goeritz, I., Falk, S., Stahl, T., Schäfers, C., Schlechtriem, C., 2013. Biomagnification and tissue distribution of perfluoroalkyl substances (PFASs) in market-size rainbow trout (Oncorhynchus mykiss). Environmental Toxicology and Chemistry 32, 2078-2088.

Grob, K., Vass, M., Biedermann, M., Neukom, H.P., 2001. Contamination of animal feed and food from animal origin with mineral oil hydrocarbons. Food additives and contaminants 18, 1-10.

Haley, N.J., Hoover, E.A., 2015. Chronic Wasting Disease of Cervids: Current Knowledge and Future Perspectives. Annual Review of Animal Biosciences 3, 305-325.

Halle, I., Ihling, M., Lahrssen-Wiederholt, M., Klaffke, H., Flachowsky, G., 2006. Carry-over of Acrylamide from Feed (Heated Potato Product) to Eggs and Body Tissues of Laying Hens. Journal für Verbraucherschutz und Lebensmittelsicherheit 1, 290-293.

Hashemi, S.R., Davoodi, H., 2011. Herbal plants and their derivatives as growth and health promoters in animal nutrition. Vet Res Commun 35, 169-180.

Hawkins, S.A.C., Simmons, H.A., Gough, K.C., Maddison, B.C., 2015. Persistence of ovine scrapie infectivity in a farm environment following cleaning and decontamination. Veterinary Record 176, 99-99.

Heres, L., Hoogenboom, R., Herbes, R., Traag, W., Urlings, B., 2010. Tracing and analytical results of the dioxin contamination incident in 2008 originating from the Republic of Ireland. Food additives \& contaminants. Part A, Chemistry, analysis, control, exposure \& risk assessment 27, 1733-1744.

Hilkens, W., 2015. De eiwit-challenge voor de Nederlandse veehoduerij. Deel 2: Alternatieven voor sojaimport verminderen importafhankelijkheid. ABN-AMRO, Amsterdam, the Netherlands, p. 11 p.

Hilkens, W., de Klerk, B., van Gestel, D., 2016. Insectenkweek: kleine sectoren, grote kansen. ABNAMRO, Amsterdam, the Netherlands, p. 38 p.

Hoogenboom, L.A., Mulder, P.P., Zeilmaker, M.J., van den Top, H.J., Remmelink, G.J., Brandon, E.F., Klijnstra, M., Meijer, G.A., Schothorst, R., Van Egmond, H.P., 2011. Carry-over of pyrrolizidine alkaloids from feed to milk in dairy cows. Food additives \& contaminants. Part A, Chemistry, analysis, control, exposure \& risk assessment 28, 359-372.

Hoogenboom, L.A., Van Eijkeren, J.C., Zeilmaker, M.J., Mengelers, M.J., Herbes, R., Immerzeel, J., Traag, W.A., 2007. A novel source for dioxins present in recycled fat from gelatin production. Chemosphere 68, 814-823.

Hoogenboom, R., Zeilmaker, M., Eijkeren, J., Kan, K., Mengelers, M., Luykx, D., Traag, W., 2010. Kaolinic clay derived PCDD/Fs in the feed chain from a sorting process for potatoes. Chemosphere 78, 99-105.

Hou, Y., Wu, Z., Dai, Z., Wang, G., Wu, G., 2017. Protein hydrolysates in animal nutrition: Industrial production, bioactive peptides, and functional significance. Journal of Animal Science and Biotechnology 8, 24.

Hsu, S.T., Ma, C.I., Hsu, S.K., Wu, S.S., Hsu, N.H., Yeh, C.C., Wu, S.B., 1985. Discovery and epidemiology of PCB poisoning in Taiwan: a four-year followup. Environmental health perspectives $59,5-10$.

Hussein, H.S., Brasel, J.M., 2001. Toxicity, metabolism, and impact of mycotoxins on humans and animals. Toxicology 167, 101-134. 
Isosaari, P., Lundebye, A.K., Ritchie, G., Lie, Ø., Kiviranta, H., Vartiainen, T., 2005. Dietary accumulation efficiencies and biotransformation of polybrominated diphenyl ethers in farmed Atlantic salmon (Salmo salar). Food Additives \& Contaminants 22, 829-837.

Jansen, L.J.M., Bolck, Y.J.C., Berendsen, B.J.A., 2016. Feather segmentation to discriminate between different enrofloxacin treatments in order to monitor off-label use in the poultry sector. Analytical and Bioanalytical Chemistry 408, 495-502.

JECFA Joint FAO/WHO Expert Committee on Food Additives., 1992. Evaluation of certain food additives and naturally occuring toxicants WHO technical report series 828 . WHO.

Jobst, H., Aldag, R., 2000. Dioxine in Lagerstätten-Tonen. Umweltwissenschaften und SchadstoffForschung 12, 2-4.

Kakar, F., Akbarian, Z., Leslie, T., Mustafa, M.L., Watson, J., van Egmond, H.P., Omar, M.F., Mofleh, J., 2010a. An outbreak of hepatic veno-occlusive disease in Western afghanistan associated with exposure to wheat flour contaminated with pyrrolizidine alkaloids. J Toxicol 2010, 313280.

Kakar, F., Akbarian, Z., Leslie, T., Mustafa, M.L., Watson, J., van Egmond, H.P., Omar, M.F., Mofleh, J., 2010b. An outbreak of hepatic veno-occlusive disease in Western afghanistan associated with exposure to wheat flour contaminated with pyrrolizidine alkaloids. Journal of toxicology 2010, 313280.

Kan, C.A., Meijer, G.A.L., 2007. The risk of contamination of food with toxic substances present in animal feed. Animal Feed Science and Technology 133, 84-108.

Kan, C.A., Traag, W.A., Hoogenboom, L.A.P., 2003. Voorkomen van PAK's in voer, omgeving van dieren, melken zuivelproducten alsmede een oriënterende studie in melkvee. ID-Lelystad, Lelystad.

Khatibi, P.A., McMaster, N.J., Musser, R., Schmale, D.G., 2014. Survey of Mycotoxins in Corn Distillers' Dried Grains with Solubles from Seventy-Eight Ethanol Plants in Twelve States in the U.S. in 2011. Toxins 6, 1155-1168.

Kierkegaard, A., Asplund, L., de Wit, C.A., McLachlan, M.S., Thomas, G.O., Sweetman, A.J., Jones, K.C., 2007. Fate of higher brominated PBDEs in lactating cows. Environmental science \& technology 41, 417-423.

Kierkegaard, A., De Wit, C.A., Asplund, L., McLachlan, M.S., Thomas, G.O., Sweetman, A.J., Jones, K.C., 2009. A mass balance of tri-hexabrominated diphenyl ethers in lactating cows. Environmental science \& technology 43, 2602-2607.

Kiser, B., Clifton, A., Vickerson, A., Magdani, N., 2016. Circular economy: Getting the circulation going. 531, 443-446.

Kowalczyk, J., Ehlers, S., Oberhausen, A., Tischer, M., Fürst, P., Schafft, H., Lahrssen-Wiederholt, M., 2013. Absorption, Distribution, and Milk Secretion of the Perfluoroalkyl Acids PFBS, PFHxS, PFOS, and PFOA by Dairy Cows Fed Naturally Contaminated Feed. Journal of Agricultural and Food Chemistry 61, 2903-2912.

Krippner, J., Falk, S., Brunn, H., Georgii, S., Schubert, S., Stahl, T., 2015. Accumulation Potentials of Perfluoroalkyl Carboxylic Acids (PFCAs) and Perfluoroalkyl Sulfonic Acids (PFSAs) in Maize (Zea mays). Journal of Agricultural and Food Chemistry 63, 3646-3653.

Kuratsune, M., Yoshimura, T., Matsuzaka, J., Yamaguchi, A., 1972. Epidemiologic study on Yusho, a Poisoning Caused by Ingestion of Rice Oil Contaminated with a Commercial Brand of Polychlorinated Biphenyls. Environmental health perspectives 1, 119-128.

Li, X., Rezaei, R., Li, P., Wu, G., 2011. Composition of amino acids in feed ingredients for animal diets. Amino Acids 40, 1159-1168.

Li, Z., Ma, Z., van der Kuijp, T.J., Yuan, Z., Huang, L., 2014. A review of soil heavy metal pollution from mines in China: Pollution and health risk assessment. Science of The Total Environment 468-469, 843-853.

Liem, A.K.D., Hoogerbrugge, R., Kootstra, P.R., van der Velde, E.G., de Jong, A.P.J.M., 1991. Occurrence of dioxins in cow's milk in the vicinity of municipal waste incinerators and a metal reclamation plant in the Netherlands. Chemosphere 23, 1675-1684.

Lim, S.J., Kim, S.S., Pham, M.A., Song, J.W., Cha, J.H., Kim, J.D., Kim, J.U., Lee, K.J., 2010. Effects of fermented cottonseed and soybean meal with phytase supplementation on gossypol degradation, phosphorus availability, and growth performance of olive flounder (Paralichthys olivaceus). Fish Aqua Science 13, 284-293. 
Liu, X., Han, L., Veys, P., Baeten, V., Jiang, X., Dardenne, P., 2011. An overview of the legislation and light microscopy for detection of processed animal proteins in feeds. Microsc. Res. Tech. 74, 735-743.

Love, D.C., Halden, R.U., Davis, M.F., Nachman, K.E., 2012. Feather Meal: A Previously Unrecognized Route for Reentry into the Food Supply of Multiple Pharmaceuticals and Personal Care Products (PPCPs) Environ. Sci. Technol. 46, 3795-3802.

MacLachlan, D.J., 2011. Estimating the transfer of contaminants in animal feedstuffs to livestock tissues, milk and eggs: a review. Animal Production Science 51, 1067-1078.

Maes, J., De Meulenaer, B., Van Heerswynghels, P. et al., 2005. Removal of dioxins and PCB from fish oil by activated carbon and its influence on the nutritional quality of the oil. J Amer Oil Chem Soc 82: 593.

Majumdar, A., Boetel, M.A., Jaronski, S.T., 2008. Discovery of Fusarium solani as a naturally occurring pathogen of sugarbeet root maggot (Diptera: Ulidiidae) pupae: Prevalence and baseline susceptibility. Journal of Invertebrate Pathology 97, 1-8.

Malisch, R., Kotz, A., 2014. Dioxins and PCBs in feed and food--review from European perspective. The Science of the total environment 491-492, 2-10.

Marnane, I., 2012. Comprehensive environmental review following the pork PCB/dioxin contamination incident in Ireland. Journal of Environmental Monitoring 14, 2551-2556.

Mauro, A., Battilani, P., Cotty, P.J., 2015. Atoxigenic Aspergillus flavus endemic to Italy for biocontrol of aflatoxins in maize. Biocontrol 60, 125-134.

Mekonnen, T.H., Mussone, P.G., Stashko, N., Choi, P.Y., Bressler, D.C., 2013. Recovery and characterization of proteinacious material recovered from thermal and alkaline hydrolyzed specified risk materials. Process Biochemistry 48, 885-892.

Ministerie van Infrastructuur en Waterstaat., 2017. Sectorplan 65 Dierlijk afval, https://lap3.nl/sectorplannen/sectorplannen/dierlijk-afval/.

Mol, J.G.J., Rijk, T.C.d., Egmond, H.J.v., Jong, J.d., 2014. Occurence of mycotoxins and pesticides in straw and hay used as animal feed. RIKILT Wageningen UR, Wageningen.

Morley, R.S., Chen, S., Rheault, N., 2003. Assessment of the risk factors related to bovine spongiform encephalopathy. Revue scientifique et technique (International Office of Epizootics) 22, 157-178.

Mulder, P.P.J., Beumer, B., Oosterink, E., de Jong, J., 2009. Dutch survey pyrrolizidine alkaloids in animal forage. RIKILT report 2009.018, 1-45.

Mulder, P.P.J., Lopez, P., These, A., Preiss-Weigert, A., Castellari, M., 2015. Occurrence of pyrrolizidine alkaloids in food. EFSA Supporting publication EN-859, p. 114.

Nácher-Mestre, J., Serrano, R., Beltrán, E., Pérez-Sánchez, J., Silva, J., Karalazos, V., Hernández, F., Berntssen, M.H.G., 2015. Occurrence and potential transfer of mycotoxins in gilthead sea bream and Atlantic salmon by use of novel alternative feed ingredients. Chemosphere 128, 314-320.

NEVEDI, 2011. Voer gemedicineerd met antibiotica

NEVEDI, 2016a. Factsheet verduurzamen grondstoffen, p. 4.

NEVEDI, 2016b. Wijzer over grondstoffen, https://www.nevedi.nl/nieuws/nieuwsoverzicht/nieuwsbericht?newsitemid=7964917760.

Nicholson, F.A., Chambers, B.J., Williams, J.R., Unwin, R.J., 1999. Heavy metal contents of livestock feeds and animal manures in England and Wales. Bioresource Technology 70, 23-31.

Noorlander, C.W., v.L.S., te Biesebeek, J.D., Mengelers, M.J.B., Zeilmaker, M.J., 2011. Levels of Perfluorinated Compounds in Food and Dietary Intake of PFOS and PFOA in The Netherlands. Journal of Agricultural and Food Chemistry 59, 7496-7505.

Nordkvist, E., Zuidema, T., Herbes, R.G., Berendsen, B.J.A., 2016. Occurrence of chloramphenicol in cereal straw in north-western Europe. Food Additives \& Contaminants: Part A 33, 798-803.

NVWA, Monitoring aanwezigheid van genetisch gemodificeerde organismen in levensmiddelen en diervoeders. Resultaten 2008-2013 - Fact sheet, p. 7 p.

NVWA, 2014. Resultaten van het NVWA Nationaal Plan Diervoeders 2014 - Monitoringsprogramma voor ongewenste stoffen in diervoeder en diervoederingrediënten (vertrouwelijk). NVWA, Utrecht, the Netherlands.

NVWA, 2015. Resultaten van het NVWA Nationaal Plan Diervoeders 2015 - Monitoringsprogramma voor ongewenste stoffen in diervoeder en diervoederingrediënten (vertrouwelijk). NVWA, Utrecht, the Netherlands.

NVWA, 2017a. Naleving regels bij productie gemedicineerd diervoeder onder de maat.

NVWA, 2017b. Nationaal Plan Diervoeders 2017, p. 19 p. 
Ortiz, X., Guerra, P., Díaz-Ferrero, J., Eljarrat, E., Barceló, D., 2011. Diastereoisomer- and enantiomer-specific determination of hexabromocyclododecane in fish oil for food and feed. Chemosphere 82, 739-744.

Pabst, K., Mathar, W., Palavinskas, R., Meisel, H., Bluthgen, A., Klaffke, H., 2005. Acrylamideoccurrence in mixed concentrate feed for dairy cows and carry-over into milk. Food additives and contaminants 22, 210-213.

Panda, A.K., Sastry, V.R.B., 2007. Scope of the utilization of unconventional oilseed-meals for poultry feeding. Livestock International 11, 17-20.

Papargyropoulou, E., Lozano, R., Steinberger, J., Wright, N., Ujang, Z., 2014. The food waste hierarchy as a framework for the management of food surplus and food waste. Journal of Cleaner Production 76, 106-115.

Pfister, J.A., Cook, D., Gardner, D.R., 2011. Cattle grazing toxic delphinium andersonii in south-central idaho. 64, 664-668.

Prince, M.J., Bailey, J.A., Barrowman, P.R., Bishop, K.J., Campbell, G.R., Wood, J.M., 2003. Bovine spongiform encephalopathy. OIE Revue Scientifique et Technique 22, 37-60.

Pritzkow, S., Morales, R., Moda, F., Khan, U., Telling, Glenn C., Hoover, E., Soto, C., 2015. Grass Plants Bind, Retain, Uptake, and Transport Infectious Prions. Cell Reports 11, 1168-1175.

Prusiner, S.B., 1998. Prions. Proceedings of the National Academy of Sciences USA 95, 13363-13383.

Pulina, G., Battacone, G., Brambilla, G., Cheli, F., Danieli, P.P., Masoero, F., Pietri, A., Ronchi, B., 2014. An Update on the Safety of Foods of Animal Origin and Feeds. Italian Journal of Animal Science 13, 3571.

Quiniou, N., Quinsac, A., Crepon, K., Evrard, J., Peyronnet, C., Bourdillon, A., Royer, E., Etienne, M., 2012. Effects of feeding $10 \%$ rapeseed meal (Brassica napus) during gestation and lactation over three reproductive cycles on the performance of hyperprolific sows and their litters. Can J Anim Sci 92, 513-524.

Randall, L., Heinrich, K., Horton, R., Brunton, L., Sharman, M., Bailey-Horne, V., Sharma, M., McLaren, I., Coldham, N., Teale, C., Jones, J., 2014. Detection of antibiotic residues and association of cefquinome residues with the occurrence of Extended-Spectrum $\beta$-Lactamase (ESBL)-producing bacteria in waste milk samples from dairy farms in England and Wales in 2011. Research in Veterinary Science 96, 15-24.

Rejtharova, M., Rejthar, L., Cackova, K., Bures, J., Vernerova, E., Hera, A., 2017. Observation of residues in tissues of chickens exposed to low dietary concentrations of chloramphenicol. Food additives \& contaminants. Part A, Chemistry, analysis, control, exposure \& risk assessment 34, 542-546.

Römkens, P.F.A.M., Groenenberg, J.E., Rietra, R.P.J.J., De Vries, W., 2007. Onderbouwing LAC-2006 waarden en overzicht van bodem-plant relaties ten behoeve van de Riscotoolbox. ALTERRA, Wageningen, The Netherlands, p. 104 p.

Rychlik, M., Humpf, H.U., Marko, D., Danicke, S., Mally, A., Berthiller, F., Klaffke, H., Lorenz, N., 2014. Proposal of a comprehensive definition of modified and other forms of mycotoxins including "masked" mycotoxins. Myco Res 30, 197-205.

SCF., 2001. OPINION OF THE SCIENTIFIC COMMITTEE ON FOOD ON THE RISK ASSESSMENT OF DIOXINS AND DIOXIN-LIKE PCBS IN FOOD. Scientific Committee on Food.

Schimming, T., Jenett-Siems, K., Mann, P., Tofern-Reblin, B., Milson, J., Johnson, R.W., Deroin, T., Austin, D.F., Eich, E., 2005. Calystegines as chemotaxonomic markers in the Convolvulaceae. Phytochemistry 66, 469-480.

Schoss, S., Adamse, P., Immerzeel, J., Traag, W., van Egmond, H.J., de Jong, J., Hoogenboom, L.A., 2012. Levels and trends of dioxins and dioxin-like PCBs in feed. RIKILT, Wageningen, the Netherlands, p. 132 p.

Scudamore, K.A., Patel, S., 2008. The fate of deoxynivalenol and fumonisins in wheat and maize during commercial breakfast cereal production. World Mycotoxin Journal 1, 437-448.

Securefeed, 2016a. Risicoclassificatie Diervoeders.

SecureFeed, 2016b. SecureFeed Caring for Food safety http://www.securefeed.eu/.

Shams, M., Mitterbauer, R., Corradini, R., Wiesenberger, G., Dall'Asta, C., Schuhmacher, R., Krska, R., Adam, G., Berthiller, F., 2011. Isolation and characterization of a new less-toxic derivative of the Fusarium mycotoxin diacetoxyscirpenol after thermal treatment. Journal of Agricultural and Food Chemistry 59, 9709-9714. 
Shi, Y., Wang, J., Pan, Y., Cai, Y., 2012. Tissue distribution of perfluorinated compounds in farmed freshwater fish and human exposure by consumption. Environmental Toxicology and Chemistry 31, 717-723.

SKAL, 2017. SKAL biocontrole www.skal.nl.

Sprong, R.C., Boon, P.E., 2015. Dietary exposure to cadmium in the Netherlands. RIVM, Bilthoven, the Netherlands, p. 50 p.

Stevens, R., 2016. Mengvoerafzet blijft onder druk staan, Boerderij.

Stolker, A.A.M., Manti, V., Zuidema, T., van Egmond, H., Deckers, E.R., Herbes, R., Hooglugt, J., Olde Heuvel, E., de Jong, J., 2013. Carry-over of veterinary drugs from medicated to nonmedicated feeds in commercial feed manufacturing plants. Food Additives \& Contaminants: Part A 30, 1100-1107.

Suominen, K., Hallikainen, A., Ruokojärvi, P., Airaksinen, R., Koponen, J., Rannikko, R., Kiviranta, H., 2011. Occurrence of PCDD/F, PCB, PBDE, PFAS, and Organotin Compounds in Fish Meal, Fish Oil and Fish Feed. Chemosphere 85, 300-306.

Tan, E.T.T., Fletcher, M.T., Yong, K.W.L., D'Arcy, B.R., Al Jassim, R., 2014. Determination of hepatotoxic indospicine in Australian camel meat by ultra-performance liquid chromatographytandem mass spectrometry. Journal of Agricultural and Food Chemistry 62, 1974-1979.

Tittlemier, S.A., Roscoe, M., Trelka, R., Patrick, S.K., Bamforth, J.M., Grafenhan, T., Schlichting, L., Fu, B.X., 2014. Fate of moniliformin during milling of Canadian Durum wheat, processing, and cooking of spaghetti. Can J Plant Sci 94, 555-563.

Tlustos, C., Sheridan, M., O'Sullivan, D., Anderson, W., Flynn, A., 2012. The dioxin contamination incident in Ireland, 2008: analytical results and congener patterns. Food additives \& contaminants. Part A, Chemistry, analysis, control, exposure \& risk assessment 29, 128-138.

Traag, W., Kotz, A., van der Weg, G., Malisch, R., Hoogenboom, R., 2009. BIOASSAY DIRECTED DETECTION OF BROMINATED DIOXINS IN THE FEED ADDITIVE CHOLIN CHLORIDE. Organohalogen compounds 71.

Traag, W.A., Kan, C.A., van der Weg, G., Onstenk, C., Hoogenboom, L.A., 2006. Residues of dioxins (PCDD/Fs) and PCBs in eggs, fat and livers of laying hens following consumption of contaminated feed. Chemosphere 65, 1518-1525.

Van Asselt, E.D., Kowalczyk, J., Van Eijkeren, J.C.H., Zeilmaker, M.J., Ehlers, S., Fürst, P., Lahrssen-Wiederhol, M., van der Fels-Klerx, H.J., 2013. Transfer of perfluorooctane sulfonic acid (PFOS) from contaminated feed to dairy milk. Food Chemistry 141, 1489-1495.

Van den Berg, M., Birnbaum, L.S., Denison, M., De Vito, M., Farland, W., Feeley, M., Fiedler, H., Hakansson, H., Hanberg, A., Haws, L., Rose, M., Safe, S., Schrenk, D., Tohyama, C., Tritscher, A., Tuomisto, J., Tysklind, M., Walker, N., Peterson, R.E., 2006. The 2005 World Health Organization Reevaluation of Human and Mammalian Toxic Equivalency Factors for Dioxins and Dioxin-Like Compounds. Toxicological Sciences 93, 223-241.

van der Fels-Klerx, H.J., Adamse, P., de Jong, J., Hoogenboom, R., de Nijs, M., Bikker, P., 2017. A model for risk-based monitoring of contaminants in feed ingredients. Food Control 72, Part B, 211-218.

van der Fels-Klerx, H.J., Booij, C.J., 2010. Perspectives for geographically oriented management of fusarium mycotoxins in the cereal supply chain. Journal of food protection 73, 1153-1159.

van der Fels-Klerx, H.J., Camenzuli, L., 2016. Effects of Milk Yield, Feed Composition, and Feed Contamination with Aflatoxin B1 on the Aflatoxin M1 Concentration in Dairy Cows' Milk Investigated Using Monte Carlo Simulation Modelling. Toxins (Basel) 8.

van der Roest, J., B.-B.M., Bondt, N., Ipema, A.H., Verdonk, J.M.A., 2004. Beheersing van kritische punten in de diervoederketen ter ondersteuning van het toezichtsarrangement. RIKILT p. 47.

van der Steen, J., 2014. Wintervoer, High Fructose Corn Syrup (HFCS) en Hydroxymethylfurfural (HMF).

Van Eijkeren, J.C., Zeilmaker, M.J., Kan, C.A., Traag, W.A., Hoogenboom, L.A., 2006. A toxicokinetic model for the carry-over of dioxins and PCBs from feed and soil to eggs. Food additives and contaminants 23, 509-517.

van Larebeke, N., Hens, L., Schepens, P., Covaci, A., Baeyens, J., Everaert, K., Bernheim, J.L., Vlietinck, R., De Poorter, G., 2001. The Belgian PCB and dioxin incident of January-June 1999: exposure data and potential impact on health. Environmental health perspectives 109, 265-273. 
van Leeuwen, S.P.J., van Velzen, M.J.M., Swart, C.P., van der Veen, I., Traag, W.A., de Boer, J., 2009. Halogenated Contaminants in Farmed Salmon, Trout, Tilapia, Pangasius, and Shrimp. Environmental science \& technology 43, 4009-4015.

van Raamsdonk, L.W., 2007. A survey on the presence of undesireable botanic substances in feed in the European Union. RIKILT.

van Raamsdonk, L.W.D., Ozinga, W.A., Hoogenboom, L.A.P., Mulder, P.P.J., Mol, J.G.J., Groot, M.J., van der Fels-Klerx, H.J., de Nijs, M., 2015. Exposure assessment of cattle via roughages to plants producing compounds of concern. Food Chemistry 189, 27-37.

van Rooijen, C., Bosch, G., van der Poel, A.F.B., Wierenga, P.A., Alexander, L., Hendriks, W.H., 2014. Quantitation of Maillard Reaction Products in Commercially Available Pet Foods. Journal of Agriculture and Food Chemistry 62, 8883-8891.

Wang, A.P., Zhang, J.M., Meng, Y.L., Deng, L.Q., Lv, Y.F., Li, C., Wang, J.Q., 2012. Effects of different sources and levels of dietary gossypol on gossypol residues in plasma and milk of lactating cows. J Dairy Sci 95, 5127-5132.

Welch, K.D., Lee, S.T., Panter, K.E., Gardner, D.R., 2014. A study on embryonic death in goats due to Nicotiana glauca ingestion. Toxicon 90, 64-69.

Werneck de Carvalho, A., Gomes Natal, D.I., da Silva, C.O., de Souza Dantas, M.I., Gonçalves de Barros, E., Rocha Ribeiro, S.M., Brunoro Costa, N.M., Duarte Martino, H.S., 2013. Heat-treatment reduces anti-nutritional phytochemicals and maintains protein quality in genetically improved hulled soybean flour. Food Science and Technology (Campinas) 33, 310-315.

Wocławek-Potocka, I., Mannelli, C., Boruszewska, D., Kowalczyk-Zieba, I., Waśniewski, T., Skarzyński, D.J., 2013. Diverse effects of phytoestrogens on the reproductive performance: Cow as a model. International Journal of Endocrinology 2013.

World Organisation for Animal Health., 2017. Annual incidence rate BSE http://www.oie.int/animalhealth-in-the-world/bse-specific-data/annual-incidence-rate.

Xu, S., Reuter, T., Gilroyed, B.H., Mitchell, G.B., Price, L.M.D., S., Braithwaite, S.L., Graham, C., Czub, S., Leonard, J.J., Balachandran, A., Neumann, N.F., Belosevic, M., Mcallister, T.A., 2014. Biodegradation of Prions in Compost. Environmental science \& technology 48, 6909-6918.

Zafeiraki, E., Costopoulou, D., Vassiliadou, I., Leondiadis, L., Dassenakis, E., Hoogenboom, R.L.A.P., van Leeuwen, S.P.J., 2016a. Perfluoroalkylated substances (PFASs) in home and commercially produced chicken eggs from the Netherlands and Greece. Chemosphere 144, 2106-2112.

Zafeiraki, E., Vassiliadou, I., Costopoulou, D., Leondiadis, L., Schafft, H.A., Hoogenboom, R.L.A.P., van Leeuwen, S.P.J., 2016b. Perfluoroalkylated substances in edible livers of farm animals, including depuration behaviour in young sheep fed with contaminated grass. Chemosphere 156, 280-285.

Zhang, F., Li, Y., Yang, M., Li, W., 2012. Content of Heavy Metals in Animal Feeds and Manures from Farms of Different Scales in Northeast China. International Journal of Environmental Research and Public Health 9, 2658-2668.

Zuidema, T., van Holthoon, F.L., van Egmond, H.J., Bikker, P., Aarts, H.J.M., Olde Heuvel, E., 2010. Omvang en implicaties van antibiotica-versleping in mengvoeders voor varkens RIKILT, Wageningen, the Netherlands. 
RIKILT Wageningen University \& Research Postbus 230

6700 AE Wageningen

T 0317480256

www.wur.nl/rikilt

RIKILT-rapport 2019.002
De missie van Wageningen University \& Research is 'To explore the potential of nature to improve the quality of life'. Binnen Wageningen University \& Research bundelen Wageningen University en gespecialiseerde onderzoeksinstituten van Stichting Wageningen Research hun krachten om bij te dragen aan de oplossing van belangrijke vragen in het domein van gezonde voeding en leefomgeving. Met ongeveer 30 vestigingen, 5.000 medewerkers en 10.000 studenten behoort Wageningen University \& Research wereldwijd tot de aansprekende kennisinstellingen binnen haar domein. De integrale benadering van de vraagstukken en de samenwerking tussen verschillende disciplines vormen het hart van de unieke Wageningen aanpak. 



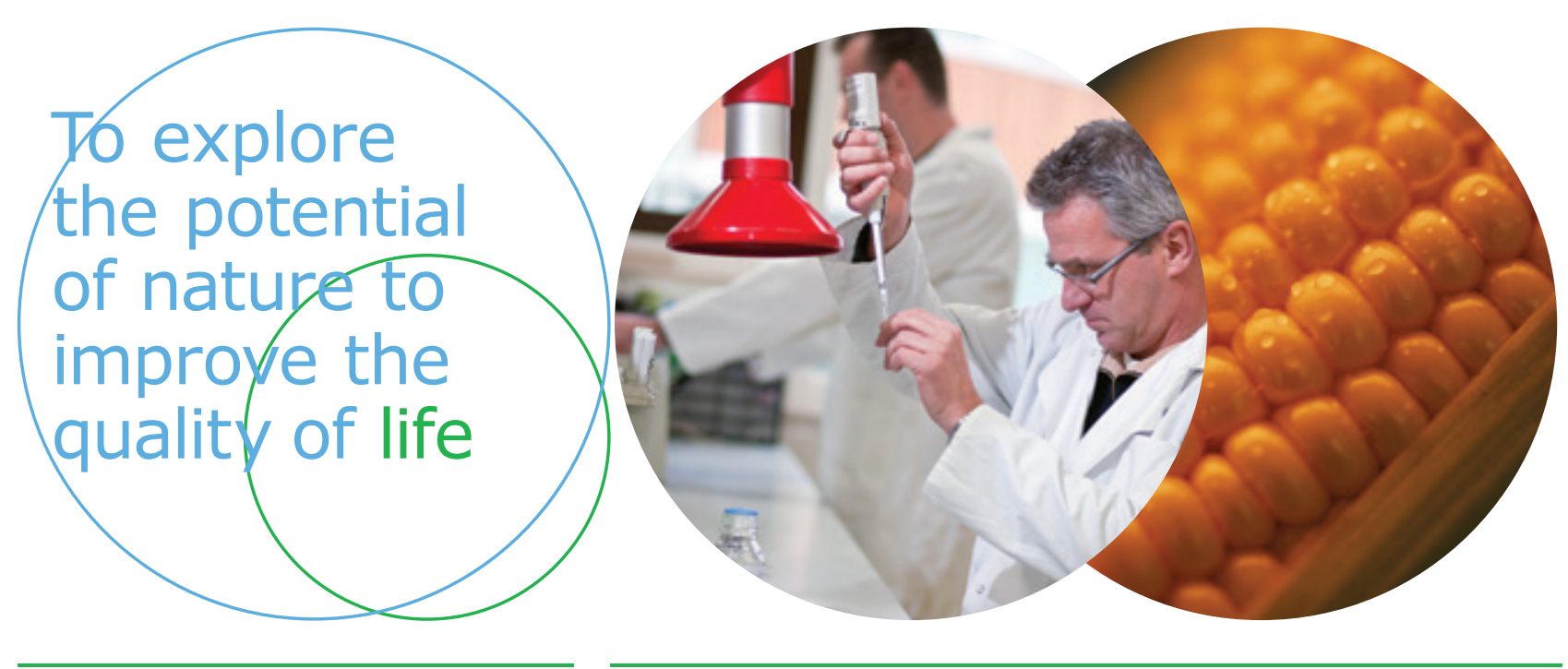

RIKILT Wageningen University \& Research Postbus 230

6700 AE Wageningen

T 0317480256

www.wur.nl/rikilt

RIKILT-rapport 2019.002
De missie van Wageningen University \& Research is 'To explore the potential of nature to improve the quality of life'. Binnen Wageningen University \& Research bundelen Wageningen University en gespecialiseerde onderzoeksinstituten van Stichting Wageningen Research hun krachten om bij te dragen aan de oplossing van belangrijke vragen in het domein van gezonde voeding en leefomgeving. Met ongeveer 30 vestigingen, 5.000 medewerkers en 10.000 studenten behoort Wageningen University \& Research wereldwijd tot de aansprekende kennisinstellingen binnen haar domein. De integrale benadering van de vraagstukken en de samenwerking tussen verschillende disciplines vormen het hart van de unieke Wageningen aanpak. 